\title{
6. BURIED BASEMENT TRANSECT (SITES 1028, 1029, 1030, 1031, AND 1032)
}

\author{
Shipboard Scientific Party ${ }^{2}$
}

\section{HOLE 1028A}

Position: $47^{\circ} 51.479^{\prime} \mathrm{N}, 128^{\circ} 30.289^{\prime} \mathrm{W}$

Start hole: $1230 \mathrm{hr}, 5$ August 1996

End hole: $1630 \mathrm{hr}, 6$ August 1996

Time on hole: $28.00 \mathrm{hr}$ (1.17 days)

Seafloor (drill pipe measurement from rig floor, mbrf): 2670.8

Total depth (drill pipe measurement from rig floor, mbrf): 2802.3

Distance between rig floor and sea level (m): 11.4

Water depth (drill pipe measurement from sea level, m): 2659.4

Penetration (mbsf): 131.5

Coring totals:

Type: APC; Number: 12; Cored: $108.2 \mathrm{~m}$; Recovered: $107.52 \mathrm{~m}$ (99.4\%)

Type: XCB; Number: 3; Cored: 23.3 m; Recovered: 17.39 m (74.6\%)

Total: Number: 15; Cored: 131.5 m; Recovered: 124.91 m (95.0\%)

Formation:

Unit I: 0.0-107.87 mbsf; Quaternary

Interbeds of sand and silt turbidites and hemipelagic mud

Unit II: $107.87-132.48$ mbsf; Quaternary

Hemipelagic mud

Unit 1: 132.48-133.66 mbsf; Quaternary

Basalt

\section{HOLE 1029A}

\section{Position: $47^{\circ} 49.901^{\prime} \mathrm{N}, 128^{\circ} 22.597^{\prime} \mathrm{W}$}

Start hole: $2100 \mathrm{hr}, 7$ August 96

End hole: 1100 hr, 9 August 96

Time on hole: $38.00 \mathrm{hr}$ (1.58 days)

Seafloor (drill pipe measurement from rig floor, mbrf): 2664.0

Total depth (drill pipe measurement from rig floor, mbrf): 2887.0

Distance between rig floor and sea level (m): 11.4

Water depth (drill pipe measurement from sea level, m): 2652.6

Penetration (mbsf): 223.0

Coring totals:

Type: APC; Number: 12; Cored: 109.0 m; Recovered: 105.09 m (96.4\%)

Type: XCB; Number: 13; Cored: 114.0 m; Recovered: 97.88 m (85.9\%)

Total: Number: 25; Cored: 223.0 m; Recovered: 202.97 m (91.0\%)

\section{Formation:}

Unit I: 0.0-197.39 mbsf; Quaternary

Interbeds of sand and silt turbidites and hemipelagic mud

'Davis, E.E., Fisher, A.T., Firth, J.V., et al., 1997. Proc. ODP, Init. Repts, 168: College Station, TX (Ocean Drilling Program).

${ }^{2}$ Shipboard Scientific Party is given in the list preceding the Table of Contents.
Unit II: 197.39-220.07 mbsf; Quaternary Interbeds of sand and silt turbidites and hemipelagic mud Unit 1: 220.07-223.0 mbsf; Pliocene Basalt

\section{HOLE 1030A}

Position: $47^{\circ} 53.847^{\prime} \mathrm{N}, 128^{\circ} 33.711^{\prime} \mathrm{W}$

Start hole: $1100 \mathrm{hr}, 9$ August 96

End hole: $0015 \mathrm{hr}, 10$ August 96

Time on hole: $13.25 \mathrm{hr}$ ( 0.55 days)

Seafloor (drill pipe measurement from rig floor, mbrf): Not available Total depth (drill pipe measurement from rig floor, mbrf): 2595.5

Distance between rig floor and sea level (m): 11.4

Water depth (drill pipe measurement from sea level, m): 2574.3

Penetration (mbsf): 11.0

Coring totals:

Type: APC; Number: 1; Washed: 9.5 m; Recovered: 9.76 m (102.7\%)

Formation:

Unit I: 0-9.5 mbsf; Quaternary

Interbeds of silty turbidites and hemipelagic mud

\section{HOLE 1030B}

Position: $47^{\circ} 53.847^{\prime} \mathrm{N}, 128^{\circ} 33.711^{\prime} \mathrm{W}$

Start hole: $0015 \mathrm{hr}, 10$ August 96

End hole: $0915 \mathrm{hr}, 10$ August 96

Time on hole: $9.0 \mathrm{hr}$ ( 0.38 days)

Seafloor (drill pipe measurement from rig floor, mbrf): 2584.5

Total depth (drill pipe measurement from rig floor, mbrf): 2633.0

Distance between rig floor and sea level (m): 11.5

Water depth (drill pipe measurement from sea level, m): 2573.0

Penetration (mbsf): 48.5

Coring totals:

Type: APC; Number: 5; Cored: $41.0 \mathrm{~m}$; Recovered: $43.69 \mathrm{~m}$ (106.6\%)

Type: XCB; Number: 1; Cored: 7.5 m; Recovered: 0.42 m (5.6\%)

Total: Number: 6; Cored: 48.5; Recovered: $44.11 \mathrm{~m}$ (91.0\%)

Formation:

Unit I: 0-41.42 mbsf; Quaternary

Interbeds of silt turbidites, hemipelagic mud, and carbonate-rich mud

\section{HOLE 1031A}

Position: $47^{\circ} 53.400^{\prime} \mathrm{N}, 128^{\circ} 33.970^{\prime} \mathrm{W}$ 
Start hole: $0915 \mathrm{hr}, 10$ August 96

End hole: 0930 hr, 11 August 96

Time on hole: $24.25 \mathrm{hr}$ (1.01 days)

Seafloor (drill pipe measurement from rig floor, mbrf): 2599.2

Total depth (drill pipe measurement from rig floor, mbrf): 2642.0

Distance between rig floor and sea level (m): 11.5

Water depth (drill pipe measurement from sea level, m): 2587.7

Penetration (mbsf): 42.8

Coring totals:

Type: APC; Number: 5; Cored: 41.3 m; Recovered: 42.18 m (102.1\%)

Type: XCB; Number: 1; Cored: $1.5 \mathrm{~m}$; Recovered: $0.38 \mathrm{~m}(25.3 \%)$

Total: Number: 6; Cored: 42.8 m; Recovered 42.56 m (99.4\%)

Formation:

Unit I: 0-41.3 mbsf; Quaternary

Interbeds of silt turbidites, hemipelagic mud, and carbonate-rich mud

Unit 1: 41.3-42.8 mbsf; Quaternary

Basalt

\section{HOLE 1032A}

Position: $47^{\circ} 46.773^{\prime} \mathrm{N}, 128^{\circ} 07.341^{\prime} \mathrm{W}$

Start hole: $1200 \mathrm{hr}, 11$ August 96

End hole: 0000 hr, 14 August 96

Time on hole: $84.00 \mathrm{hr}$ (3.50 days)

Seafloor (drill pipe measurement from rig floor, mbrf): 2656.0

Total depth (drill pipe measurement from rig floor, mbrf): 2994.4

Distance between rig floor and sea level (m): 15.5

Water depth (drill pipe measurement from sea level, m): 2644.5

Penetration (mbsf): 338.4

Coring totals:

Type: RCB; Number: 16; Cored: 153.9 m; Recovered: 50.86 m (33.0\%)

Formation:

Unit I: 184.5-272.47 mbsf; Quaternary

Interbeds of silt turbidites, hemipelagic mud, and carbonate-rich mud

Unit II: 272.47-290.29 mbsf; Quaternary

Hemipelagic mud and carbonate-rich mud

Units 1 and 2: 290.29-338.4 mbsf; Pliocene

Basalt

\section{SITE GEOPHYSICS}

Objectives for drilling along the Buried Basement Transect (Sites 1028 through 1032) are discussed in detail in the "Introduction and Summary" chapter (this volume), and an extensive discussion of site survey data are provided there and in Davis et al. (this volume). The regional context of this transect is shown in the composite profile (Fig. 5, "Introduction and Summary" chapter [back-pocket foldout]). The sites are situated over crust ranging from about 1.4 to $2.7 \mathrm{Ma}$ in age, 40 to $75 \mathrm{~km}$ east of the crest of the Juan de Fuca Ridge, and roughly 21 to $56 \mathrm{~km}$ east of the nearest area of extensive basement outcrop. The sites fill the gap between the Hydrothermal Transition and Rough Basement Transects and complete a systematic suite of sites on this ridge flank that range in age from less than 1.0 to $3.6 \mathrm{Ma}$ and in hydrothermal setting from a few kilometers to many tens of kilometers from direct basement pathways for hydrothermal recharge. Primary goals for drilling along the Buried Basement Transect included determining "equilibrium" basement fluid compositions at a range of temperatures and determining the total heat loss from young lithosphere.

The local geologic context of Sites 1028, 1029, and 1032 is illustrated in Figure 1. Individual shotpoint traces for each site are shown in Figure 2, and seismic profile locations are shown in Figure 3. With the exception of the buried ridge where Sites 1030 and 1031 were located, the Buried Basement Transect is characterized by low local basement relief, typically less than $100 \mathrm{~m}$, and a regionally continuous sediment cover that averages about $300 \mathrm{~m}$ in thickness. There are no known exposures of basement rocks closer than the extensive area of outcrop near the ridge crest, with the exception of the small outcrops in the vicinity of the Rough Basement Transect and a seamount located about $55 \mathrm{~km}$ south of Sites 1032. Sites 1028, 1029, and 1032, are located 26,37, and $56 \mathrm{~km}$ from the area of outcropping crust near the crest of the Juan de Fuca Ridge. Holes at each of these sites were drilled into local basement ridges to minimize drilling times and to ensure that the local hydrologic setting was consistent from site to site. Local sediment thickness ranges from $0.165 \mathrm{~s}$ (two-way traveltime) at Site 1028, $0.245 \mathrm{~s}$ at Site 1029, and $0.340 \mathrm{~s}$ at Site 1032 (Fig. 2).

Numerous attempts to measure seafloor heat flow along the Buried Basement Transect have been thwarted by a shallow sandy layer that prevented penetration of gravity-driven heat probes and corers (see Davis et al., this volume). Based on the systematic trend of heatflow values across the Hydrothermal Transition Transect and Sites 1030 and 1031, it was anticipated that the eastern three sites of the Buried Basement Transect would represent fully isolated hydrothermal conditions.

Sites 1030 and 1031 are situated $21 \mathrm{~km}$ from the area of outcrop along a linear buried basement ridge that stands about $50 \mathrm{~m}$ above the igneous crustal surface to the west and $150 \mathrm{~m}$ above an adjacent valley to the east (Fig. 1). This ridge is similar in many ways to the ridge targeted by the Rough Basement Transect Site 1026. The relief of the ridge confined a sediment distributary system early in the depositional history of the area. A levee deposit now buries the ridge and is disconformably overlain by sediments of the next distributary channel to the east where Sites 1028, 1029, and 1032 are located. The thickness of sediment burying the ridge is typically less than $100 \mathrm{~m}$; natural overpressure of fluids in the ridge and the low hydraulic resistance of the locally thin sediment cover results in upward seepage of basement hydrothermal fluids. Composition of interstitial water squeezed from gravity and piston cores collected over the ridge bore a clear signature of this seepage and suggested that basement water is characterized by anomalously high chlorinity, indicating an unusually high degree of water/rock interaction at this site (Wheat and Mottl, 1994).

The pattern of heat flow over the buried ridge at these sites (see Davis et al., this volume) is identical to that over the ridge at Site 1026 and appears to be the simple consequence of the variations in thickness of the thermally and hydrologically resistive seal over a permeable basement that is maintained at a uniform temperature by efficient hydrothermal heat transport. Rates of seepage through the sediments above the ridge estimated from geochemical profiles (Wheat and Mottl, 1994) are thermally insignificant.

\section{OPERATIONS}

Site 1028

\section{Hole 1028A}

The 31.0-nmi transit to Site 1028 (proposed site HT-5A) was made at a speed of $8.4 \mathrm{kt}$. A couple of hours were spent at reduced speed $(6.0 \mathrm{kt})$ so that another test of the seismic streamer could be made. Once on site, the beacon was released, and an advanced hydraulic piston corer/extended core barrel (APC/XCB) bottom-hole assembly (BHA) was made up and run to the seafloor. APC coring proceeded to a depth of 108.2 meters below seafloor (mbsf) (Table 1) 

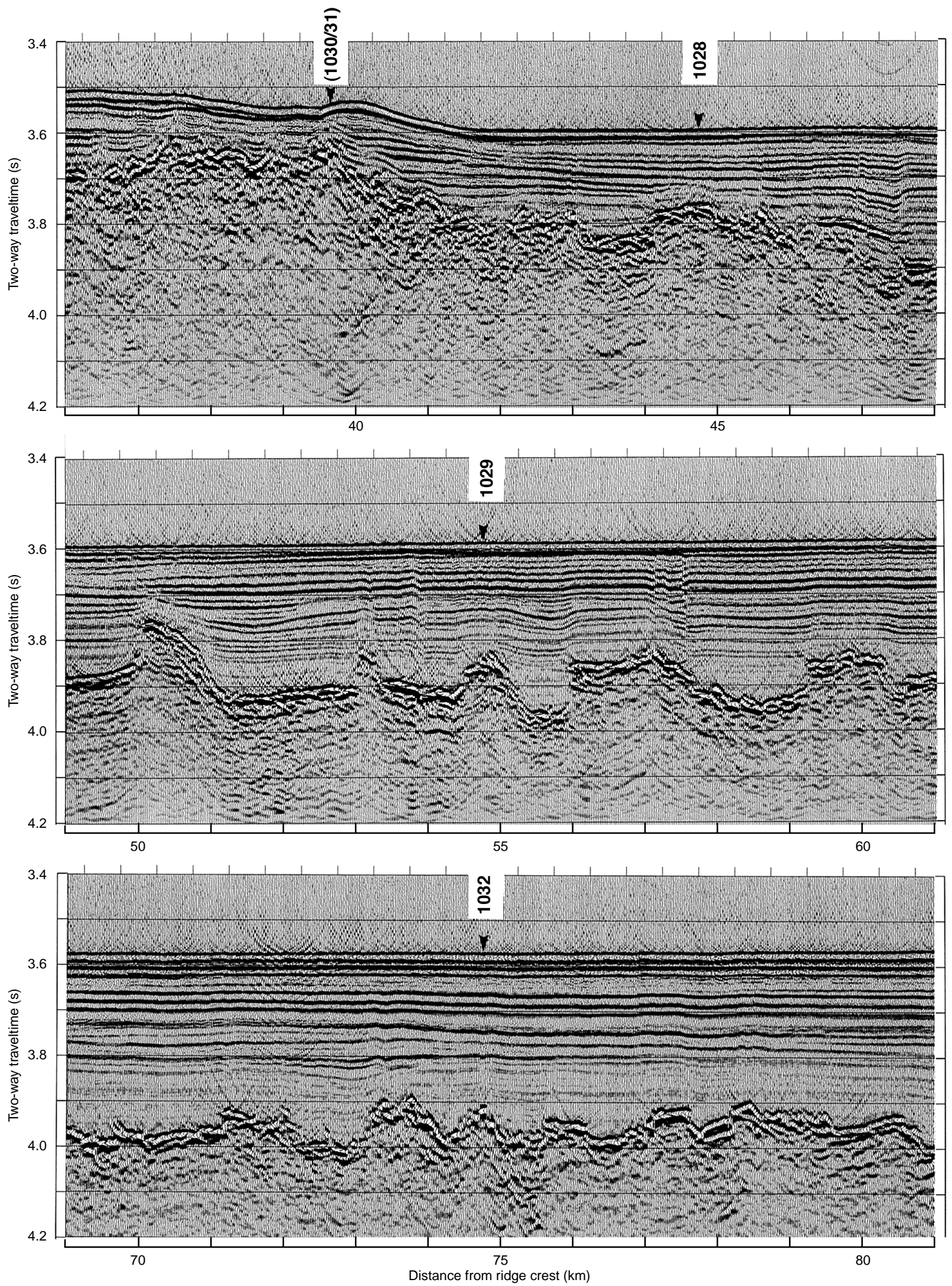

Figure 1. Seismic reflection profiles along which holes of the Buried Basement Sites 1030, 1031, 1028, 1029, and 1032 were drilled (see Fig. 3 for location of profiles). All seismic data were collected using a 1.5-L $\left(90-\mathrm{in}^{3}\right)$ Generator-Injector gun source and a digital acquisition and processing system operated by the University of Bremen. Positions of Sites 1030 and 1031 lie structurally along strike to the north of the line (see Fig. 4, "Hydrothermal Transect" chapter, this volume). 

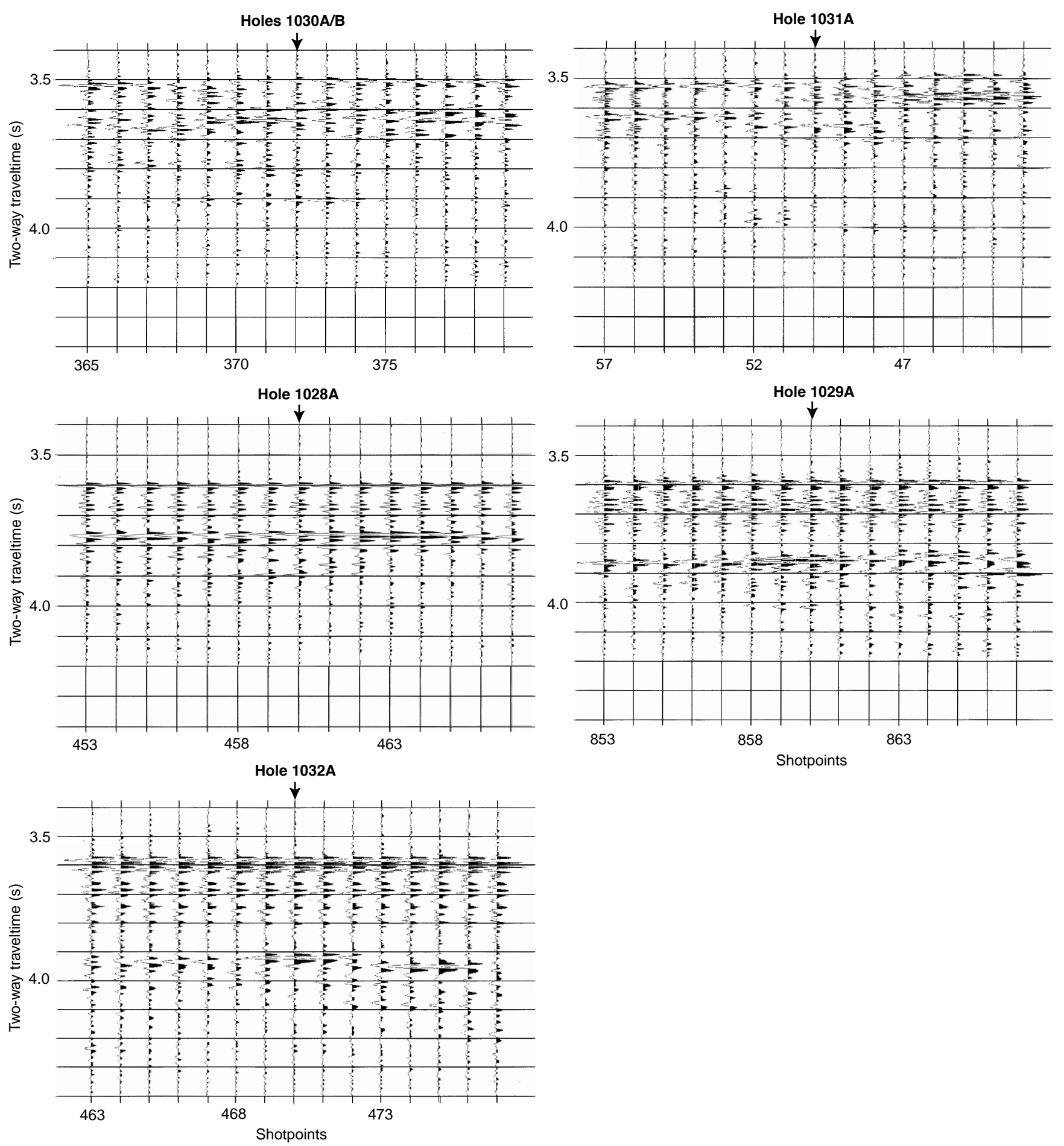

Figure 2. Trace-by-trace seismic reflection data collected in the immediate vicinity of Sites 1030, 1031, 1028, 1029, and 1032 (see Fig. 4, "Hydrothermal Transect" chapter, this volume, and Fig. 3 for locations of drill sites relative to seismic reflection profiles). Shots are spaced $25 \mathrm{~m}$ apart.

with four Adara temperature tool measurements taken. Maximum overpulls of 50,000 $\mathrm{lb}$ with the Adara temperature shoes and 30,000 $\mathrm{lb}$ without an Adara shoe were recorded. XCB coring continued to a final total depth (TD) of 131.5 mbsf. Basement was contacted at a depth of $130.5 \mathrm{mbsf}$ in Core 168-1028A-15X, and $1 \mathrm{hr}$ was spent coring basalt with a hard-formation cutting shoe. The Davis/Villinger Temperature Probe (DVTP) was deployed twice in the XCB cored interval. The weather had moderated significantly, and within $0.5 \mathrm{hr}$ of completing the pipe trip the ship was under way to proposed site PP-
5A (Hole 1026B) to deploy the fourth and last Circulation Obviation Retrofit Kit (CORK) of the leg.

\section{Site 1029}

\section{Hole 1029A}

After completion of Site 1026, the ship transited for $2.5 \mathrm{hr}$ to Site 1029. The BHA was made up and run to bottom for a routine APC/ $\mathrm{XCB}$ cored hole. While advancing to the APC shoot depth, the driller 


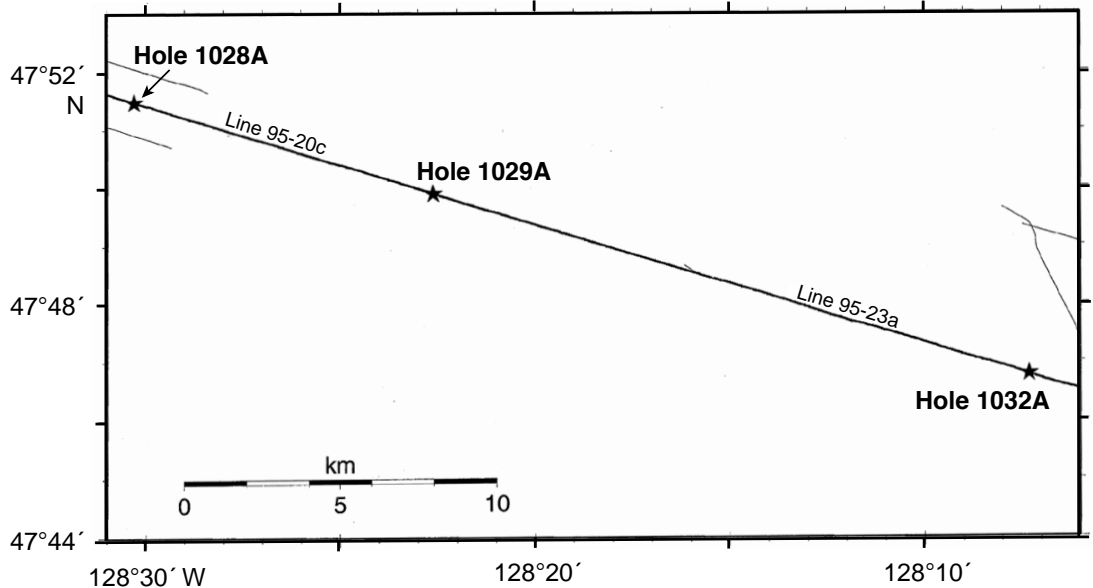

Figure 3. Hole positions along the Rough Basement Transect, along with seismic profile locations. Positions of Sites 1030 and 1031 are shown in Figure 4 in the "Hydrothermal Transition Transect" chapter (this volume).

Table 1. Coring summary for Sites 1028 through 1032.

\begin{tabular}{|c|c|c|c|c|c|c|}
\hline Core & $\begin{array}{l}\text { Date } \\
(1996)\end{array}$ & $\begin{array}{l}\text { Time } \\
\text { (UTC) }\end{array}$ & $\begin{array}{l}\text { Depth } \\
\text { (mbsf) }\end{array}$ & $\begin{array}{c}\text { Length } \\
\text { cored } \\
(\mathrm{m})\end{array}$ & $\begin{array}{l}\text { Length } \\
\text { recovered } \\
\text { (m) }\end{array}$ & $\begin{array}{c}\text { Recovery } \\
(\%)\end{array}$ \\
\hline $\begin{array}{c}168-1028 \mathrm{~A}- \\
1 \mathrm{H} \\
2 \mathrm{H} \\
3 \mathrm{H} \\
4 \mathrm{H} \\
5 \mathrm{H} \\
6 \mathrm{H} \\
7 \mathrm{H} \\
8 \mathrm{H} \\
9 \mathrm{H} \\
10 \mathrm{H} \\
11 \mathrm{H} \\
12 \mathrm{H} \\
13 \mathrm{X} \\
14 \mathrm{X} \\
15 \mathrm{X}\end{array}$ & $\begin{array}{l}6 \text { Aug } \\
6 \text { Aug } \\
6 \text { Aug } \\
6 \text { Aug } \\
6 \text { Aug } \\
6 \text { Aug } \\
6 \text { Aug } \\
6 \text { Aug } \\
6 \text { Aug } \\
6 \text { Aug } \\
6 \text { Aug } \\
6 \text { Aug } \\
6 \text { Aug } \\
6 \text { Aug } \\
6 \text { Aug }\end{array}$ & $\begin{array}{l}0205 \\
0300 \\
0350 \\
0450 \\
0545 \\
0645 \\
0725 \\
0825 \\
0905 \\
1000 \\
1040 \\
1115 \\
1310 \\
1405 \\
1710\end{array}$ & $\begin{array}{c}0.0-3.7 \\
3.7-13.2 \\
13.2-22.7 \\
22.7-32.2 \\
32.2-41.7 \\
41.7-51.2 \\
51.2-60.7 \\
60.7-70.2 \\
70.2-79.7 \\
79.7-89.2 \\
89.2-98.7 \\
98.7-108.2 \\
108.2-114.2 \\
114.2-123.8 \\
123.8-131.5\end{array}$ & $\begin{array}{l}3.7 \\
9.5 \\
9.5 \\
9.5 \\
9.5 \\
9.5 \\
9.5 \\
9.5 \\
9.5 \\
9.5 \\
9.5 \\
9.5 \\
6.0 \\
9.6 \\
7.7 \\
\end{array}$ & $\begin{array}{r}3.71 \\
6.06 \\
9.83 \\
10.02 \\
9.45 \\
10.06 \\
9.87 \\
10.02 \\
9.88 \\
9.65 \\
9.72 \\
9.25 \\
7.73 \\
0.00 \\
9.66 \\
\end{array}$ & $\begin{array}{r}100.0 \\
63.8 \\
103.0 \\
105.5 \\
99.5 \\
105.9 \\
104.0 \\
105.5 \\
104.0 \\
101.0 \\
102.0 \\
97.3 \\
129.0 \\
0.0 \\
125.0 \\
\end{array}$ \\
\hline Coring totals: & & & & 131.5 & 124.91 & 95.0 \\
\hline $\begin{array}{c}168-1029 \mathrm{~A}- \\
1 \mathrm{H} \\
2 \mathrm{H} \\
3 \mathrm{H} \\
4 \mathrm{H} \\
5 \mathrm{H} \\
6 \mathrm{H} \\
7 \mathrm{H} \\
8 \mathrm{H} \\
9 \mathrm{H} \\
10 \mathrm{H} \\
11 \mathrm{H} \\
12 \mathrm{H} \\
13 \mathrm{X} \\
14 \mathrm{X} \\
15 \mathrm{X} \\
16 \mathrm{X} \\
17 \mathrm{X} \\
18 \mathrm{X} \\
19 \mathrm{X} \\
20 \mathrm{X} \\
21 \mathrm{X} \\
22 \mathrm{X} \\
23 \mathrm{X} \\
24 \mathrm{X} \\
25 \mathrm{X}\end{array}$ & $\begin{array}{l}\text { 8 Aug } \\
\text { 8 Aug } \\
\text { 8 Aug } \\
\text { 8 Aug } \\
\text { 8 Aug } \\
\text { 8 Aug } \\
\text { 8 Aug } \\
\text { 8 Aug } \\
\text { 8 Aug } \\
8 \text { Aug } \\
8 \text { Aug } \\
8 \text { Aug } \\
8 \text { Aug } \\
8 \text { Aug } \\
8 \text { Aug } \\
9 \text { Aug } \\
9 \text { Aug } \\
9 \text { Aug } \\
9 \text { Aug } \\
9 \text { Aug } \\
9 \text { Aug } \\
9 \text { Aug } \\
9 \text { Aug } \\
9 \text { Aug } \\
9 \text { Aug }\end{array}$ & $\begin{array}{l}1025 \\
1130 \\
1210 \\
1305 \\
1350 \\
1445 \\
1530 \\
1620 \\
1705 \\
1800 \\
1850 \\
1950 \\
2055 \\
2245 \\
2335 \\
0130 \\
0230 \\
0335 \\
0535 \\
0645 \\
0735 \\
0935 \\
1105 \\
1330 \\
1555\end{array}$ & $\begin{array}{c}0.0-4.5 \\
4.5-14.0 \\
14.0-23.5 \\
23.5-33.0 \\
33.0-42.5 \\
42.5-52.0 \\
52.0-61.5 \\
61.5-71.0 \\
71.0-80.5 \\
80.5-90.0 \\
90.0-99.5 \\
99.5-109.0 \\
109.0-114.9 \\
114.9-120.8 \\
120.8-130.4 \\
130.4-140.0 \\
140.0-149.6 \\
149.6-159.2 \\
159.2-168.8 \\
168.8-178.4 \\
178.4-188.0 \\
188.0-197.6 \\
197.6-207.2 \\
207.2-216.8 \\
216.8-223.0\end{array}$ & $\begin{array}{l}4.5 \\
9.5 \\
9.5 \\
9.5 \\
9.5 \\
9.5 \\
9.5 \\
9.5 \\
9.5 \\
9.5 \\
9.5 \\
9.5 \\
5.9 \\
5.9 \\
9.6 \\
9.6 \\
9.6 \\
9.6 \\
9.6 \\
9.6 \\
9.6 \\
9.6 \\
9.6 \\
9.6 \\
6.2 \\
\end{array}$ & $\begin{array}{r}4.50 \\
9.59 \\
9.20 \\
10.05 \\
7.23 \\
9.24 \\
9.89 \\
6.88 \\
9.86 \\
10.12 \\
8.66 \\
9.87 \\
4.82 \\
7.78 \\
1.02 \\
6.86 \\
9.90 \\
9.91 \\
9.87 \\
9.34 \\
4.52 \\
9.79 \\
9.79 \\
9.82 \\
4.46 \\
\end{array}$ & $\begin{array}{r}100.0 \\
101.0 \\
96.8 \\
105.8 \\
76.1 \\
97.2 \\
104.0 \\
72.4 \\
104.0 \\
106.5 \\
91.1 \\
104.0 \\
81.7 \\
132.0 \\
10.6 \\
71.4 \\
103.0 \\
103.0 \\
103.0 \\
97.3 \\
47.1 \\
102.0 \\
102.0 \\
102.0 \\
71.9 \\
\end{array}$ \\
\hline Coring totals: & & & & 223.0 & 202.97 & 91.0 \\
\hline
\end{tabular}

\begin{tabular}{|c|c|c|c|c|c|c|}
\hline Core & $\begin{array}{l}\text { Date } \\
(1996)\end{array}$ & $\begin{array}{l}\text { Time } \\
\text { (UTC) }\end{array}$ & $\begin{array}{l}\text { Depth } \\
\text { (mbsf) }\end{array}$ & $\begin{array}{l}\text { Length } \\
\text { cored } \\
(\mathrm{m})\end{array}$ & $\begin{array}{l}\text { Length } \\
\text { recovered } \\
\text { (m) }\end{array}$ & $\begin{array}{c}\text { Recovery } \\
(\%)\end{array}$ \\
\hline $\begin{array}{l}\text { 168-1030A- } \\
1 \mathrm{~W}\end{array}$ & 10 Aug & 0700 & $0.0-9.5$ & 9.5 & 9.76 & (wash core) \\
\hline $\begin{array}{l}\text { Coring totals: } \\
\text { Washing totals: } \\
\text { Combined totals: }\end{array}$ & & & & $\begin{array}{l}0.0 \\
9.5 \\
9.5\end{array}$ & $\begin{array}{l}0.00 \\
9.76 \\
9.76\end{array}$ & \\
\hline $\begin{array}{l}168-1030 \mathrm{~B}- \\
1 \mathrm{H} \\
2 \mathrm{H} \\
3 \mathrm{H} \\
4 \mathrm{H} \\
5 \mathrm{H} \\
6 \mathrm{X}\end{array}$ & $\begin{array}{l}10 \mathrm{Aug} \\
10 \mathrm{Aug} \\
10 \mathrm{Aug} \\
10 \mathrm{Aug} \\
10 \mathrm{Aug} \\
10 \mathrm{Aug}\end{array}$ & $\begin{array}{l}0745 \\
0835 \\
0915 \\
1000 \\
1045 \\
1415\end{array}$ & $\begin{array}{c}0.0-4.0 \\
4.0-13.5 \\
13.5-23.0 \\
23.0-32.5 \\
32.5-41.0 \\
41.0-48.5\end{array}$ & $\begin{array}{l}4.0 \\
9.5 \\
9.5 \\
9.5 \\
8.5 \\
7.5\end{array}$ & $\begin{array}{l}4.06 \\
9.97 \\
9.96 \\
9.95 \\
9.75 \\
0.42\end{array}$ & $\begin{array}{r}101.0 \\
105.0 \\
105.0 \\
105.0 \\
115.0 \\
5.6\end{array}$ \\
\hline Coring totals: & & & & 48.5 & 44.11 & 91.0 \\
\hline $\begin{array}{l}168-1031 \mathrm{~A}- \\
1 \mathrm{H} \\
2 \mathrm{H} \\
3 \mathrm{H} \\
4 \mathrm{H} \\
5 \mathrm{H} \\
6 \mathrm{X}\end{array}$ & $\begin{array}{l}11 \text { Aug } \\
11 \text { Aug } \\
11 \text { Aug } \\
11 \text { Aug } \\
11 \text { Aug } \\
11 \text { Aug }\end{array}$ & $\begin{array}{l}0220 \\
0325 \\
0425 \\
0530 \\
0725 \\
0940\end{array}$ & $\begin{array}{c}0.0-8.8 \\
8.8-18.3 \\
18.3-27.8 \\
27.8-37.3 \\
37.3-41.3 \\
41.3-42.8\end{array}$ & $\begin{array}{l}8.8 \\
9.5 \\
9.5 \\
9.5 \\
4.0 \\
1.5\end{array}$ & $\begin{array}{r}8.86 \\
9.10 \\
9.93 \\
10.30 \\
3.99 \\
0.38 \\
\end{array}$ & $\begin{array}{r}100.0 \\
95.8 \\
104.0 \\
108.4 \\
99.7 \\
25.3 \\
\end{array}$ \\
\hline Coring totals: & & & & 42.8 & 42.56 & 99.4 \\
\hline $\begin{array}{l}168-1032 \mathrm{~A}- \\
1 \mathrm{R} \\
2 \mathrm{R} \\
3 \mathrm{R} \\
4 \mathrm{R} \\
5 \mathrm{R} \\
6 \mathrm{R} \\
7 \mathrm{R} \\
8 \mathrm{R} \\
9 \mathrm{R} \\
10 \mathrm{R} \\
11 \mathrm{R} \\
12 \mathrm{R} \\
13 \mathrm{R} \\
14 \mathrm{R} \\
15 \mathrm{R} \\
16 \mathrm{R}\end{array}$ & $\begin{array}{l}12 \mathrm{Aug} \\
12 \mathrm{Aug} \\
12 \mathrm{Aug} \\
12 \mathrm{Aug} \\
12 \mathrm{Aug} \\
12 \mathrm{Aug} \\
12 \mathrm{Aug} \\
12 \mathrm{Aug} \\
12 \mathrm{Aug} \\
12 \mathrm{Aug} \\
13 \mathrm{Aug} \\
13 \mathrm{Aug} \\
13 \mathrm{Aug} \\
13 \mathrm{Aug} \\
13 \mathrm{Aug} \\
13 \mathrm{Aug}\end{array}$ & $\begin{array}{l}1015 \\
1210 \\
1305 \\
1500 \\
1545 \\
1635 \\
1820 \\
1920 \\
2130 \\
2230 \\
0125 \\
0630 \\
1010 \\
1410 \\
1835 \\
2120\end{array}$ & $\begin{array}{l}184.5-194.1 \\
194.1-203.7 \\
203.7-213.3 \\
213.3-222.9 \\
222.9-232.5 \\
232.5-242.1 \\
242.1-251.7 \\
251.7-261.4 \\
261.4-271.0 \\
271.0-280.6 \\
280.6-290.2 \\
290.2-299.9 \\
299.9-309.5 \\
309.5-319.1 \\
319.1-327.8 \\
327.8-338.4\end{array}$ & $\begin{array}{r}9.6 \\
9.6 \\
9.6 \\
9.6 \\
9.6 \\
9.6 \\
9.6 \\
9.7 \\
9.6 \\
9.6 \\
9.6 \\
9.7 \\
9.6 \\
9.6 \\
8.7 \\
10.6\end{array}$ & $\begin{array}{l}1.47 \\
2.50 \\
1.86 \\
0.20 \\
5.78 \\
4.66 \\
3.74 \\
4.61 \\
0.18 \\
5.91 \\
5.27 \\
3.37 \\
4.61 \\
3.56 \\
2.27 \\
0.87\end{array}$ & $\begin{array}{r}15.3 \\
26.0 \\
19.4 \\
2.1 \\
60.2 \\
48.5 \\
38.9 \\
47.5 \\
1.9 \\
61.5 \\
54.9 \\
34.7 \\
48.0 \\
37.1 \\
26.1 \\
8.2\end{array}$ \\
\hline Coring totals: & & & & 153.9 & 50.86 & 33.0 \\
\hline
\end{tabular}

Notes: UTC $=$ Universal Time Coordinated. For each site, an expanded coring summary table that includes lengths and depths of sections and sampling comments is included on CD-ROM (back pocket).

tagged bottom. Accordingly, the bit was picked up $5 \mathrm{~m}$, and Hole 1029A was spudded. The seafloor depth was established at 2664.0 meters below rig floor (mbrf), or $7.4 \mathrm{~m}$ above the precision depth recorder (PDR) depth. Coring proceeded for 12 APC cores (Table 1), and five Adara temperature measurements through several perceived sand layers and resultant incomplete strokes until an overpull of $100,000 \mathrm{lb}$ terminated APC coring. The XCB system was used to deepen the hole with excellent core recovery until basement was tagged at a depth of $2883.5 \mathrm{mbrf}$ (219.5 mbsf). The hole was terminated at $2887.0 \mathrm{mbrf}(223.0 \mathrm{mbs})$ after coring basement for $1 \mathrm{hr}$. The

drill string was recovered to approximately $100 \mathrm{~m}$ above the seafloor, and the beacon was released/recovered. With knobby drilling joints installed through the guide horn, the ship began moving to Site 1030.

\section{Site $\mathbf{1 0 3 0}$}

\section{Hole 1030A}

Hole 1030A was located on a ridge crest with very little (approximately $40 \mathrm{~m}$ ) sediment cover overlying basement. A positioning beacon was deployed, and the drill string was spaced out for initiating 
drilling operations. To avoid hitting basement with the APC, and to allow optimal placement of the DVTP for a temperature measurement as close to basement as possible, a wash test was conducted. With a core barrel in place, the drill string was lowered with low circulation until a mudline was tagged at a depth of $2589.0 \mathrm{mbrf}$. Circulation and rotation were kept minimal until reaching a perceived basement depth of 2628.0 mbrf (39.0 mbsf). The drill string was pulled clear of the mudline, and the vessel was offset $10 \mathrm{~m}$ for spudding Hole 1030A. The drill string was spaced out for shooting APC Core 168-1030A-1H from a depth of $2586.0 \mathrm{mbrf}$, or $3.0 \mathrm{~m}$ above tag depth. The spaceout was cut closer than it would normally be because the scientists desired a minimum $6.5-7.0 \mathrm{~m}$ of core recovery on the mudline core. This was to be used for chemistry analysis that would determine the location of the next site. Two options were under consideration, and the deciding factor was to be the chemical analysis from Hole 1030A. When Core $1 \mathrm{H}$ was recovered, it contained full recovery, resulting in a missed mudline depth. The core was curated as a "wash" core (1W) from Hole 1030A (Table 1), and coring was halted after a single core. The pipe was then pulled clear of the mudline, ending operations at Hole 1030A.

\section{Hole 1030B}

The bit was placed at $2579.0 \mathrm{mbrf}$, or $7.0 \mathrm{~m}$ higher, for spudding Hole 1030B. No dynamic positioning (DP) offset was made between holes. This time, $4.01 \mathrm{~m}$ was recovered in the first core, establishing the mudline at 2584.5 mbrf. Continuous APC coring continued through Core 168-1030B-5H to a depth of $2625.5 \mathrm{mbrf}$ (41.0 mbsf; Table 1). The DVTP was then deployed for a single temperature measurement close to the top of anticipated basement. A single XCB core (6X) was then cored through the remaining sediment and into basement. The driller's basement tag depth was $2631.4 \mathrm{~m}$, or $46.9 \mathrm{mbsf}$. The drill string was pulled clear of the seabed and secured at a depth of 2469.4 mbrf (approximately $100 \mathrm{~m}$ above the seafloor) with knobby drilling joints through the guide horn. After multiple transmissions, the beacon eventually released and was recovered aboard ship. This was the first and only beacon problem experienced during the leg. Once secured, the ship began its DP move to Hole 1031A approximately $1000 \mathrm{~m}$ away.

\section{Site 1031}

\section{Hole 1031A}

The DP move to Hole 1031A was uneventful. Once on location, a positioning beacon was deployed, and the pipe was positioned to wash to basement, similar to the procedure at Site 1030 . Jetting was initiated at $1135 \mathrm{hr}$, and the pipe was advanced to a depth of 2642.5 mbrf (65.5 mbsf) where apparent basement was tagged. The pipe was pulled clear of the seabed, and the ship was offset $10 \mathrm{~m}$ west for the spudding of Hole 1031A. Apparently the PDR reading was erroneous because of a side echo from a nearby seafloor feature. After two water cores, it was decided to advance the drill string, feel for bottom, then pick back up for spudding. Two additional singles were added to the string, and seafloor was eventually tagged around $2602 \mathrm{mbrf}$. The drill pipe was placed at $2598.5 \mathrm{mbrf}$, and a mudline core totaling 8.86 $\mathrm{m}$ was recovered (Table 1). APC coring continued through Core 168$1031 \mathrm{~A}-5 \mathrm{H}$, with Adara temperature tool measurements taken on Cores $3 \mathrm{H}$ and $4 \mathrm{H}$. The DVTP was deployed after Core $4 \mathrm{H}$. Core $5 \mathrm{H}$ impacted basement and recovered approximately $4 \mathrm{~m}$ of undisturbed core, with the remainder of the material flow-in. A single XCB core (6X) was advanced $1.5 \mathrm{~m}$ into basement in just under $1 \mathrm{hr}$, recovering $0.38 \mathrm{~m}$ of basement rock. The drill string was pulled out of the hole, and the APC/XCB BHA was nondestructively tested as it reached the drill floor. Once the rig floor was secured, the beacon was recovered and the vessel departed for Site 1032 (proposed site LH-2).

\section{Site 1032}

\section{Hole $1032 A$}

The transit to the last site ( $\mathrm{LH}-2)$ took $2.5 \mathrm{hr}$ from the time the ship was under way to beacon drop. Hole $1032 \mathrm{~A}$ was spudded with a mudline tag depth of 2656.0 mbrf. Drilling with a center bit in place proceeded to a depth of $2840.5 \mathrm{mbrf}$, or $184.5 \mathrm{mbsf}$. The center bit was recovered, and a single RCB core was cut before the first of six DVTP deployments. Continuous RCB coring interspersed with DVTP measurements continued to a depth of 2947.2 mbrf (291.2 mbsf) where basement was tagged $1 \mathrm{~m}$ in on Core 168-1032A-12R. Basement coring continued to a TD of $2994.4 \mathrm{mbrf}$ (338.4 mbsf, Table 1). As the hole progressed further into basement, there was increasingly more fill between connections. Three 40-bbl sepiolite mud sweeps and one 40-bbl sweep with high-viscosity gel mud were made during basement coring to aid in cleaning the hole of cuttings. After coring was terminated, a short trip above the basement contact was made, and $14 \mathrm{~m}$ of fill was identified on bottom. Another 40-bbl sweep was made while circulating to bottom through the soft fill. A wiper trip to $100 \mathrm{mbsf}$ and back to TD was made before logging. Two additional 40-bbl sweeps of gel mud were made during the wiper trip and before displacing the hole with $123 \mathrm{bbl}$ of sepiolite mud for logging. The bit was released, and the mechanical bit release sleeve was reverse shifted. During the second run, the coring line was coated because it was the last wireline run of the leg. The pipe was pulled to a logging depth of $2746.3 \mathrm{mbrf}(90.3 \mathrm{mbsf})$ with 20 - and $30-\mathrm{ft}$ knobbies installed. The logging program consisted of three suites. The first run was made with the triple combination string, consisting of porosity, density, photoelectric effect, resistivity, and gamma-ray tools. In addition, the Lamont temperature tool was run. The first suite of logging tools reached a depth of $2938.0 \mathrm{mbrf}$ (282.0 mbsf). This was a disappointing $9.2 \mathrm{~m}$ above the basement contact. Efforts were made to go deeper, but to no avail. The caliper logs recovered during this run indicated a fairly good hole through the sediment column (11- to 12-in hole) but a very ratty hole in the deeper part of the section above basement. The second suite of logs consisted of the Formation MicroScanner and sonic tools. This suite reached a depth of $2933.0 \mathrm{mbrf}, 5 \mathrm{~m}$ shallower than the first run. Two passes with the FMS/Sonic tools were made. The third logging suite consisted of the geochemical tool string. The third deployment reached a depth of 2932.0 mbrf, another meter higher in the hole. Logging was completed by $1900 \mathrm{hr}, 14$ Aug. Drill pipe was pulled, and the rig floor was secured at $2400 \mathrm{hr}, 14$ August. The ship set sail for Victoria, British Columbia, with an estimated arrival at $2100 \mathrm{hr}, 15$ August.

\section{LITHOSTRATIGRAPHY Stratigraphic Units}

The sedimentary succession within the Buried Basement Transect area includes three lithostratigraphic units and subunits (Fig. 4). Subunit IA is Quaternary in age and composed of hemipelagic mud (clayey silt to silty clay), thin-bedded turbidites (silt to sandy silt), and thin- to thick-bedded sand turbidites. The base of Subunit IA coincides with the deepest discrete sand bed. This boundary occurs at approximately $81 \mathrm{mbsf}$ in Hole 1028A and 96 mbsf in Hole 1029A (Table 2). Most of the hemipelagic muds within Subunit IA are homogeneous, but there are local clay-rich color bands, silt laminae, zones of bioturbation, and increases in biogenic constituents, especially calcareous nannofossils. Turbidites display sharp to erosional bases, normal size grading, plane-parallel laminae, and gradational tops. Some beds also contain ripple cross-laminae, convolute laminae, or wavy laminae. Turbidite thickness usually increases as grain size coarsens. Beds of silt and sandy silt typically measure less than $10 \mathrm{~cm}$, whereas sand beds reach maximum thicknesses of more than 


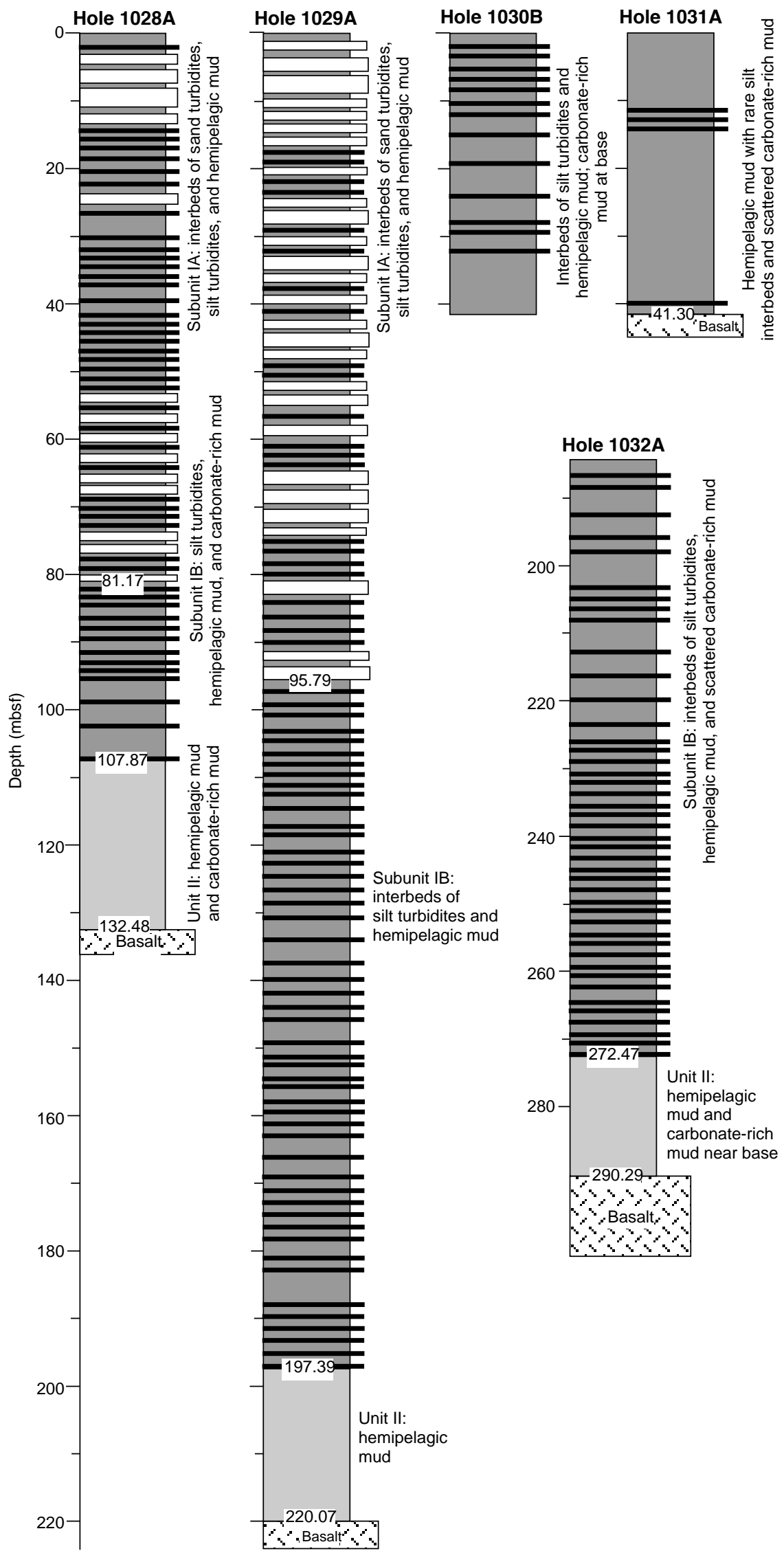

Figure 4. Stratigraphic summary for the Buried Basement Transect area. Bed thicknesses are not shown to scale. Sand $=$ white; silt turbidites $=$ black; and debrisflow deposits $=$ stippled. 
Table 2. Summary of lithostratigraphic units within the Buried Basement Transect area.

\begin{tabular}{|c|c|c|c|c|c|}
\hline Unit & Age & Lithologic character & Hole & Interval & $\begin{array}{l}\text { Thickness } \\
(\mathrm{m})\end{array}$ \\
\hline IA & Quaternary & Sand turbidites, silt turbidites, and hemipelagic mud & $\begin{array}{l}1028 \mathrm{~A} \\
1029 \mathrm{~A}\end{array}$ & $\begin{array}{l}1 \mathrm{H}-1,0 \mathrm{~cm}, \text { to } 10 \mathrm{H}-1,147 \mathrm{~cm} \\
1 \mathrm{H}-1,0 \mathrm{~cm} \text {, to } 11 \mathrm{H}-4,129 \mathrm{~cm}\end{array}$ & $\begin{array}{l}81.17 \\
95.79\end{array}$ \\
\hline IB & Quaternary & Silt turbidites, hemipelagic mud, and carbonate-rich mud & $\begin{array}{l}1028 \mathrm{~A} \\
1029 \mathrm{~A} \\
1032 \mathrm{~A}\end{array}$ & $\begin{array}{l}10 \mathrm{H}-1,147 \mathrm{~cm} \text {, to } 12 \mathrm{H}-7,17 \mathrm{~cm} \\
11 \mathrm{H}-4,129 \mathrm{~cm} \text {, to } 22 \mathrm{X}-\mathrm{CC}, 32 \mathrm{~cm} \\
1 \mathrm{R}-0,0 \mathrm{~cm} \text {, to } 10 \mathrm{R}-1,147 \mathrm{~cm}\end{array}$ & $\begin{array}{c}26.70 \\
101.60 \\
\text { Unknown }\end{array}$ \\
\hline II & Quaternary & Hemipelagic mud and carbonate-rich mud & $\begin{array}{l}1028 \mathrm{~A} \\
1029 \mathrm{~A} \\
1032 \mathrm{~A}\end{array}$ & $\begin{array}{l}12 \mathrm{H}-7,17 \mathrm{~cm} \text {, to } 15 \mathrm{X}-6,118 \mathrm{~cm} \\
22 \mathrm{X}-\mathrm{CC}, 32 \mathrm{~cm} \text {, to } 25 \mathrm{X}-3,27 \mathrm{~cm} \\
10 \mathrm{R}-1,147 \mathrm{~cm} \text {, to } 12 \mathrm{R}-1,9 \mathrm{~cm}\end{array}$ & $\begin{array}{l}24.61 \\
22.68 \\
17.82\end{array}$ \\
\hline Undifferentiated & $\begin{array}{l}\text { Quaternary } \\
\text { Quaternary }\end{array}$ & $\begin{array}{l}\text { Hemipelagic mud, silt turbidites, and carbonate-rich mud } \\
\text { Hemipelagic mud, rare silt turbidites, and carbonate-rich mud }\end{array}$ & $\begin{array}{l}1030 \mathrm{~B} \\
1031 \mathrm{~A}\end{array}$ & $\begin{array}{l}1 \mathrm{H}-1,0 \mathrm{~cm} \text {, to } 6 \mathrm{X}-\mathrm{CC}, 40 \mathrm{~cm} \\
1 \mathrm{H}-1,0 \mathrm{~cm} \text {, to } 6 \mathrm{X}-1,0 \mathrm{~cm}\end{array}$ & $\begin{array}{l}41.40 \\
41.30\end{array}$ \\
\hline
\end{tabular}

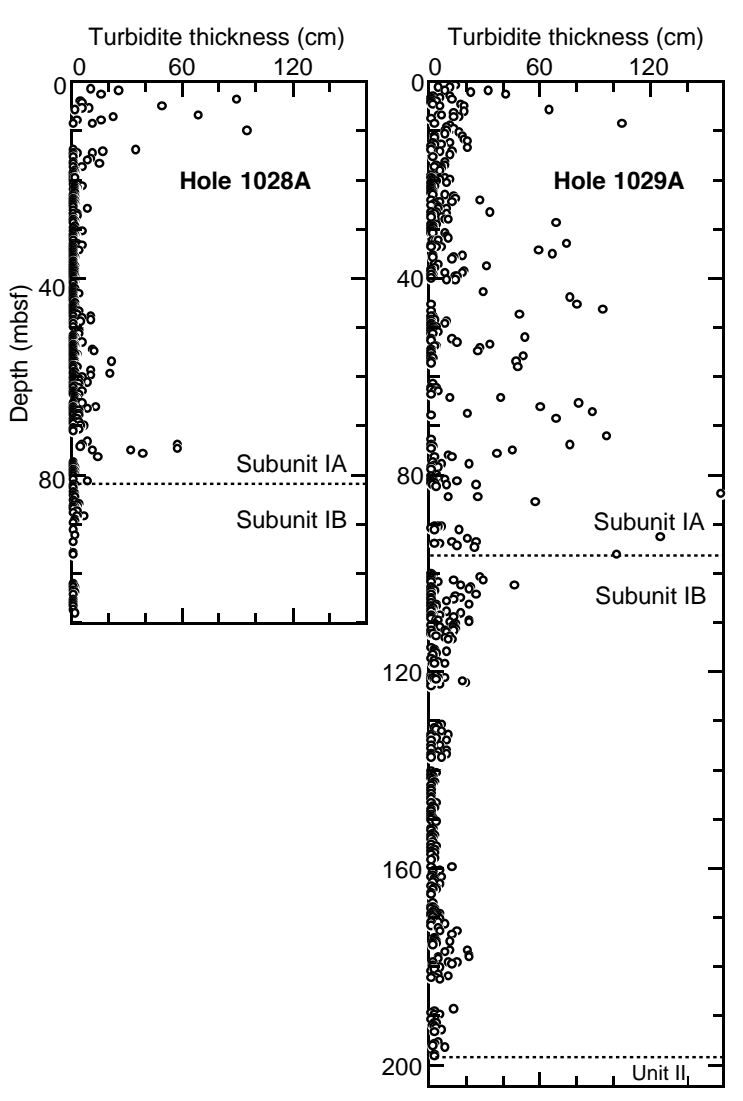

Figure 5. Depth distribution and thickness of sand turbidites and silt turbidites along the Buried Basement Transect.

$150 \mathrm{~cm}$ (Fig. 5). Some deposits are very poorly sorted, and grain support during transport of these muddy sands may have been aided by matrix strength and buoyancy, in addition to fluid turbulence.

The turbidite successions of Subunit IA differ significantly from Site 1028 to Site 1029 (Fig. 5). Sand turbidites are much more common in cores from Hole 1029A. Cores from within the upper $100 \mathrm{~m}$ of Hole 1028A, conversely, contain more thin-bedded, fine-grained turbidites. We were unable to recognize marker beds or make definitive intersite correlations among the turbidite clusters. The total thickness of Subunit IA expands by approximately $15 \mathrm{~m}$ from Site 1028 to Site 1029 . The total number of inferred gravity-flow deposits within Subunit IA decreases from 437 at Site 1028 to 388 at Site 1029 (Table 3 on CD-ROM, back pocket).

Subunit IB is Quaternary in age. These deposits are characterized by thin beds of silt and sandy silt intercalated with hemipelagic mud deposits (silty clay to clayey silt). Most of the silt beds are $1-5 \mathrm{~cm}$ in thickness, with sharp bases, plane-parallel laminae, normal size grading, and gradational tops. Ripple cross-laminae, wavy laminae, and convolute laminae also are present locally. Some of the subtle details of these deposits were destroyed by fragmentation of the cores into drilling biscuits and slurry. The hemipelagic mud deposits are superficially similar to those of Subunit IA, but they contain more highly variable admixtures of siliciclastic and biogenic constituents, particularly at Site 1028. Erratic increases in the content of calcareous nannofossils generally result in a subtle lightening of color. The top of Subunit IB was not cored at Site 1032. The base of Subunit IB coincides with the deepest discrete silt bed (Fig. 5). This boundary occurs at depths of $107.87 \mathrm{mbsf}$ (Hole 1028A), $197.39 \mathrm{mbsf}$ (Hole 1029A), and $272.47 \mathrm{mbsf}$ (Hole 1032A). Strata assigned to Subunit IB probably were deposited by thin, fine-grained, dilute turbidity currents interspersed with steady suspension fallout. Some remobilization of silt and mud by sluggish bottom currents also could have occurred.

Hemipelagic mud deposits of Unit II are Quaternary in age. Characteristic features include scattered pyrite nodules, silt and sandy-silt laminae, darker colored clay-rich bands, mottled intervals of intense bioturbation, and Zoophycos trace fossils. The thickness of Unit II ranges from $24.6 \mathrm{~m}$ in Hole $1028 \mathrm{~A}$ to $22.7 \mathrm{~m}$ in Hole $1029 \mathrm{~A}$ to 17.8 $\mathrm{m}$ in Hole 1032A. The first occurrence of basalt rubble defines the depositional boundary between Unit II and igneous basement (Fig. 4). This contact occurs in core from curatorial depths of 132.48 and 220.07 mbsf for Holes 1028A and 1029A, respectively. The basement contact is considerably deeper (290.29 mbsf) at Site 1032. Sediments immediately above the basement contact display irregular color variations, ranging from pale yellow green to grayish green and yellowish brown. This variegated appearance is probably caused by fluctuations in primary clay mineral content and biogenic carbonate content, but hydrothermal formation of clay minerals and/or Fe-Mn oxides also needs to be considered.

We did not subdivide sedimentary deposits from Holes 1030B and 1031A into stratigraphic units. Cores recovered from both holes contain approximately $41 \mathrm{~m}$ of interbedded hemipelagic mud, carbonate-rich mud, and silt to sandy silt turbidites (Fig. 4). Both sites are perched above a prominent basement high, but silty turbidites are significantly more abundant at Site 1030B. The reasons for this contrast are unclear. Many of the turbidite deposits probably were transported upslope onto the basement ridge when the surrounding basement lows remained incompletely filled. Basalt was recovered only from Hole 1031A. Drillers defined the basement contact at approximately 46.9 mbsf in Hole 1030B; the curatorial basement depth in Hole 1031A is 41.30 mbsf. The lowermost deposits at Site 1030 contain abundant nannofossil-rich intervals (especially Section 1681030B-5H-5), but there are no obvious indications of hydrothermal alteration. Basal deposits from Hole 1031A (Section 168-1031A-5H3 ), in contrast, include variegated carbonate-rich claystone, clay-rich siliciclastic mud, and two poorly sorted silt layers with irregular top and bottom contacts and considerable internal disruption. Alteration 
of these sediments by fluid flow near the basement contact seems likely.

\section{Sedimentary Petrology}

\section{Carbonate Content}

Figure 6 illustrates variations in calcium carbonate content for samples from all of the Buried Basement sites, as measured by coulometric analyses (see Table 12 on CD-ROM, back pocket). Subunit IA is characterized by relatively low weight percentages of calcium carbonate; the average values are 3.2 and $4.3 \mathrm{wt} \%$ for Sites 1028 and 1029, respectively. Subunit IB, however, varies considerably from Site 1028 to 1029 (Fig. 6). Samples from Hole 1028A contain an average of $10.0 \mathrm{wt} \%$ carbonate and a maximum of $62.3 \mathrm{wt} \%$. Most increases above $5 \mathrm{wt} \%$ occur within lighter colored, nannofossil-rich mudstones. For Hole 1029A, the mean value for Subunit IB is $4.1 \mathrm{wt} \%$, and the maximum is only $12.8 \mathrm{wt} \%$. Lutites from Unit II show similar increases in carbonate. Average and maximum values for Hole 1028A are 17.7 and $38.3 \mathrm{wt} \%$, respectively. Comparable values for Unit II samples from Hole 1029A are 4.1 and $12.8 \mathrm{wt} \%$, respectively. Carbonate contents of samples from Holes 1030B and $1031 \mathrm{~A}$ are higher, on average, than those of the other Buried Basement sites. Mean values are $9.8 \mathrm{wt} \%$ for Hole $1030 \mathrm{~B}$ and $11.3 \mathrm{wt} \%$ for Hole 1031A. Most of the carbonate-rich deposits from Hole 1030B are concentrated within the lowermost $3 \mathrm{~m}$ of sediment recovered. Carbonate fluctuations are more erratic throughout core from Hole 1031A (Fig. 6). Samples from Hole 1032A were not analyzed for carbonate.

\section{Bulk Mineralogy}

The bulk mineralogy of Subunit IA is similar to that documented in Subunit IA at the Hydrothermal Transition sites (Tables 4, 5 on CD-ROM, back pocket). Most deposits contain abundant quartz, total feldspar (plagioclase + K-feldspar), and phyllosilicates (muscovite + chlorite + illite + smectite), plus minor pyrite and amphibole. Trace minerals include pyroxenes, biotite, iron oxides, zircon, and opaque minerals (see smear-slide data on CD-ROM, back pocket). Detrital assemblages from the upper intervals of each hole display pronounced scatter because samples were taken from interbeds of sand, muddy sand, and hemipelagic mud. A negative correlation between total feldspar and total phyllosilicates is controlled largely by grain size (Fig. 7). Departures from this trend are associated with muddy sand deposits in Subunit IA and carbonate-rich muds. The relative abundance of quartz at Site 1028 displays an overall decrease with depth. Sandy turbidites from Hole 1029A, in contrast, contain significantly higher weight percentages of quartz than interbeds of hemipelagic mud, and their quartz contents are greater than those of sand deposits from Hole 1028A.

Clayey silt to silty clay deposits have similar mineralogic compositions within both Subunits IA and IB (Fig. 7). Scatter in the contents of feldspars and phyllosilicates probably is related to textural variations (i.e., silt-to-clay ratio), but there are no systematic changes in major mineral phases as a function of depth. Mudstones from Unit II, on the other hand, do show modest changes in mineralogy with depth. Total feldspar decreases with depth in Unit II at Site 1029, from an average of 26 to $20 \mathrm{wt} \%$. This decrease is more difficult to recognize at Site 1028, however, because of the influence of large increases in the calcite content on the relative abundances of the other minerals. Concomitant with the decrease in feldspar at Site 1029 is an increase in the average relative abundance of phyllosilicates (from 43 to 48 $\mathrm{wt} \%$ ). Smectite appears to be the major contributor to this enrichment of total clay minerals. There also appears to be a slight decrease in the relative abundance of pyrite with depth in Unit II. Relative mineral abundances at Sites 1030 and 1031 show no major departures from the compositions of Subunit IB and Unit II at Sites 1028 and 1029 (Fig. 7).

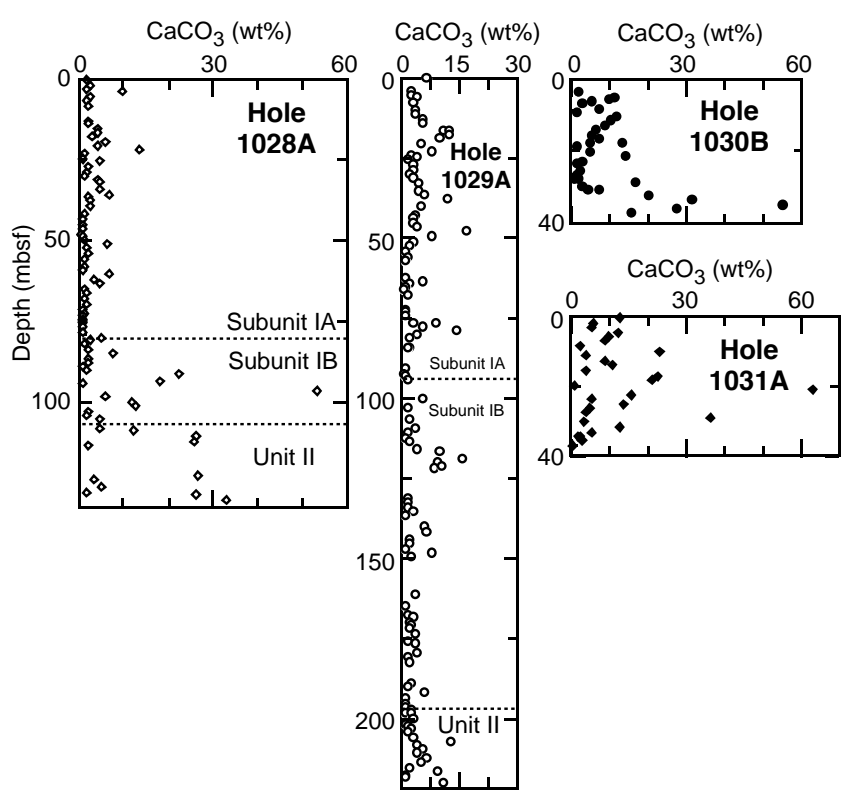

Figure 6. Contents of calcium carbonate (in weight percentage) along the Buried Basement Transect, as measured by coulometric analyses.

\section{Sediment Alteration}

Very little evidence of sediment alteration is visible in the cored sections. Smear slides show some signs of nannofossil recrystallization. Within Unit II, at both Sites 1028 and 1029, calcite recrystallization was recognized in hemipelagic muds located within $1 \mathrm{~m}$ of the basement contact. Also, distinct color variations (moderate yellow greens, yellowish browns and light bluish grays, for example) are common in most of the cores from this site within the interval immediately above the basement contact. These color changes appear, from smear-slide observations, to be the result of the formation of authigenic clays.

\section{BASEMENT LITHOLOGY, PETROLOGY, GEOCHEMISTRY, AND ALTERATION}

\section{Lithologic Units}

Within the Buried Basement Transect, basement was recovered from Holes 1028A, 1029A, 1031A, and 1032A. All of the basement consisted predominantly of aphyric, sparsely to moderately phyric, or moderately phyric plagioclase \pm olivine \pm pyroxene and olivine \pm plagioclase basalt. All of the rocks recovered are lithologically similar, consisting of pillow basalt. Lithologic units were designated on the basis of changes in mineralogy, rock texture, and grain size. Only one lithologic unit was defined for Holes 1028A, 1029A, and 1031A (i.e., pillow basalts, Unit 1; Table 6), whereas at Hole 1032A, two units were designated based on a change in whole-rock texture. Subunits (denoted by unit numbers and lowercase letters [e.g., 1a, 1f, etc.]) were based on the presence of chilled margins within the rock sequence, as well as subtle changes in grain size, from microcrystalline to cryptocrystalline; this allowed individual cooling units to be recognized and logged.

Thin sections were studied to help determine the mineralogy and petrology of the basalts from Holes 1028A, 1029A, and 1031A. Because Site 1032 was occupied at the end of Leg 168, thin-section preparation was not possible. Similarly, X-ray fluorescence (XRF) data were not available because the Buried Basement sites were occupied too late in the leg. 

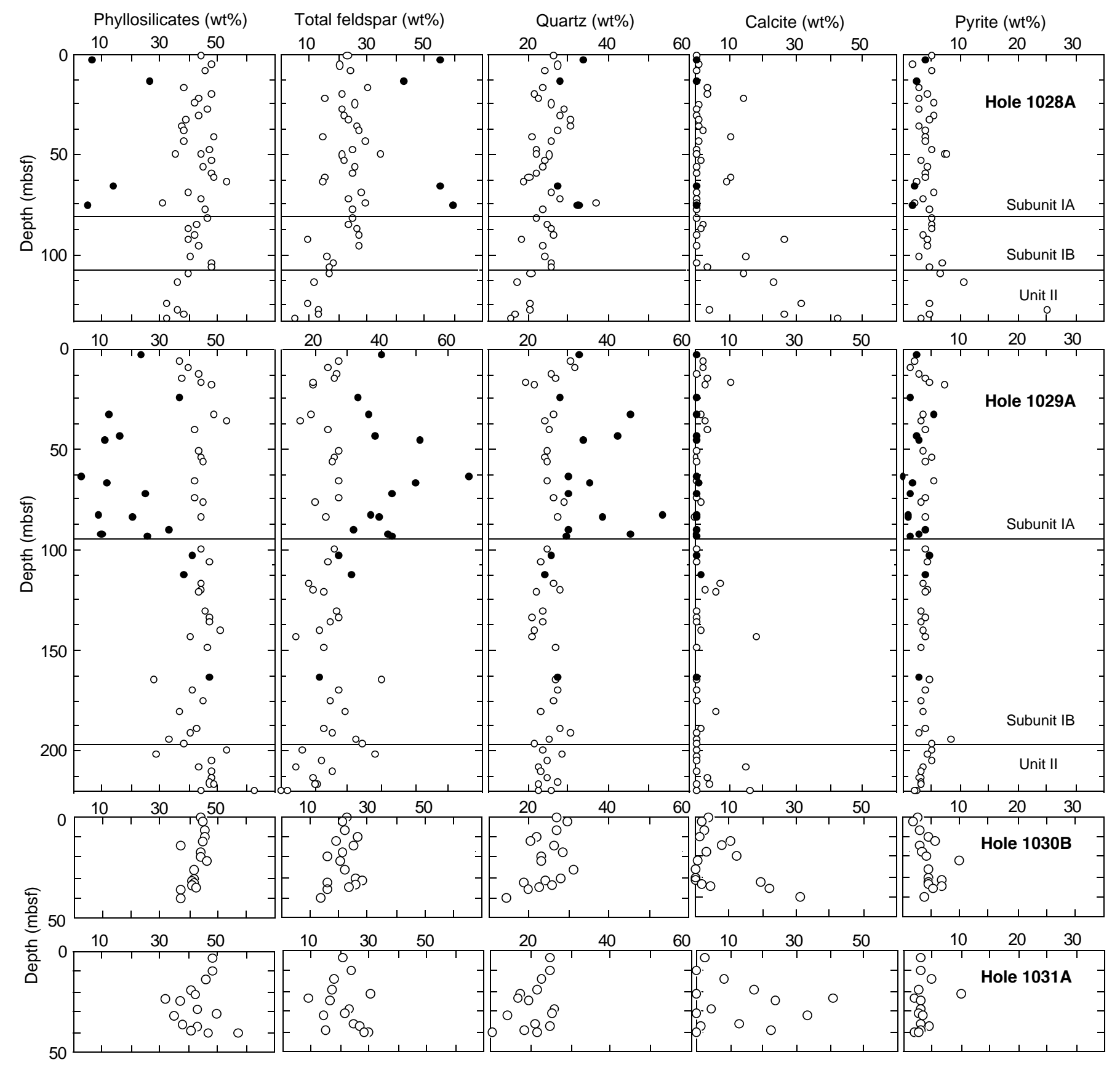

$10 \quad 20 \quad 30$

Figure 7. Depth distribution of major mineral phases (relative weight percentages) in Holes 1028A, 1029C, 1030B, and 1031A, based on X-ray diffraction analyses of bulk powders. Open circles = samples of hemipelagic mud; solid circles = samples of turbidite sand and silty sand.

\section{Pillow Basalts}

The pillow basalts from Holes $1028 \mathrm{~A}$ and $1029 \mathrm{~A}$ are sparsely to moderately phyric, containing $2 \%-5 \%$ plagioclase, $1 \%-2 \%$ olivine, and trace amounts of pyroxene, whereas the pillow basalts from Holes $1031 \mathrm{~A}$ and $1032 \mathrm{~A}$ are aphyric, containing $\leq 1 \%$ to a trace amount of olivine, plagioclase \pm pyroxene phenocrysts. In all pillow basalts, the phenocrysts are set within a glassy to microcrystalline groundmass that contains microlaths to microlites of plagioclase and/ or olivine, pyroxene, opaque oxides, and opaque sulfides. The texture of the pillow basalts varies within and between cores, from glassy to hypohyaline and hypocrystalline. The mesostasis exhibits a domi- nantly sheaf-spherulitic texture, whereas the microlites form an intersertal texture.

\section{Igneous Petrology}

Two samples from Hole 1028A, two from Hole 1029A, and one from Hole 1031A were selected for petrographic analyses, covering the different types of basalt defined at the Buried Basement sites (i.e., aphyric pillow basalts [Hole 1031A] and sparsely to moderately phyric pillow basalts [Holes 1028A and 1029A]. Table 6 summarizes the lithologic units, rock types, diagnostic features, and abundances and morphologies of the phenocryst and groundmass minerals present 
Table 6. Summary of the rock types, lithologic units, and range of phenocrysts and groundmass minerals present at Holes 1028A, 1029A, 1031A, and 1032A, listing the diagnostic petrographic features of each unit.

\begin{tabular}{|c|c|c|c|c|c|}
\hline $\begin{array}{l}\text { Hole: } \\
\text { Rock type: } \\
\text { Unit: }\end{array}$ & $\begin{array}{c}1028 \mathrm{~A} \\
\text { Sparsely to moderately phyric basalt } \\
1 \mathrm{a}-\mathrm{b}\end{array}$ & $\begin{array}{c}1029 \mathrm{~A} \\
\text { Sparsely to moderately phyric basalt } \\
1\end{array}$ & $\begin{array}{c}1031 \mathrm{~A} \\
\text { Aphyric basalt } \\
1\end{array}$ & $\begin{array}{c}1032 \mathrm{~A}^{*} \\
\text { Aphyric basalt } \\
\text { 1a-m }\end{array}$ & $\begin{array}{c}1032 \mathrm{~A}^{*} \\
\text { Aphyric basalt } \\
\text { 2a-s }\end{array}$ \\
\hline \multicolumn{6}{|l|}{ Hand specimen } \\
\hline Structure: & Pillow basalts & Pillow basalts & Pillow basalts & Pillow basalts & Pillow basalts \\
\hline Texture: & Variolitic to intersertal & Glassy to intersertal & Intersertal & Variolitic to intersertal & Glassy to intersertal \\
\hline $\begin{array}{l}\text { Grain size: } \\
\text { Crystallinity }\end{array}$ & Cryptocrystalline to microcrystalline & Cryptocrystalline to microcrystalline & Cryptocrystalline to microcrystalline & Cryptocrystalline to microcrystalline & Cryptocrystalline to microcrystalline \\
\hline $\begin{array}{l}\text { Vesicles: } \\
\text { Ving. }\end{array}$ & & & & & \\
\hline Gas (\%): & $\leq 0.5$ & $\leq 2.2$ & $\leq 1.6$ & $\leq 1$ & $\leq 3$ \\
\hline \multicolumn{6}{|l|}{$\begin{array}{l}\text { Segregation (\%): } \\
\text { Phenocrysts }\end{array}$} \\
\hline Plagioclase (\%) & $\leq 4.6$ & $1.6-2.4$ & $\leq 0.4$ & $\operatorname{Tr}$ & $\operatorname{Tr}$ \\
\hline Morphology: & Euhedral to skeletal & Euhedral to skeletal & Subhedral to skeletal & Euhedral to skeletal & Euhedral to subhedral \\
\hline Size range $(\mathrm{mm})$ : & $0.8-2.5$ & $0.5-1.6$ & $0.6-1.0$ & $\leq 4$ & $\leq 2.5$ \\
\hline Olivine (\%): & $\leq 0.6$ & 0 to tr & $\operatorname{Tr}$ & $\mathrm{Tr}$ & 0 to tr \\
\hline Morphology: & Euhedral to skeletal & Euhedral to subhedral & Euhedral & Euhedral & Euhedral \\
\hline Size range $(\mathrm{mm})$ : & $\leq 1.5$ & $0.4-0.6$ & $0.3-0.5$ & $\leq 2$ & $\leq 2$ \\
\hline Pyroxene (\%): & 0 to tr & 0 to tr & $\leq 0.2$ & 0 to tr & 0 to tr \\
\hline Morphology: & Euhedral & Subhedral & Subhedral to anhedral & Subhedral to euhedral & Euhedral to subhedral \\
\hline \multirow{2}{*}{\multicolumn{6}{|c|}{$\begin{array}{l}\text { Groundmass } \\
\text { size (mm): }\end{array}$}} \\
\hline & & & & & \\
\hline Plagioclase (\%): & $9-18$ & $\leq 6.6$ & $\leq 11.2$ & - & - \\
\hline Morphology: & Euhedral to skeletal & Euhedral to skeletal & Euhedral to skeletal & - & - \\
\hline Size range $(\mathrm{mm})$ : & $0.05-0.8$ & $0.05-0.5$ & $0.05-0.5$ & - & - \\
\hline Olivine (\%): & $1.4-3.4$ & $0 \%$ to tr & - & - & - \\
\hline Morphology: & Euhedral to skeletal & Euhedral to skeletal & - & - & - \\
\hline Size range $(\mathrm{mm})$ : & $0.05-0.6$ & $0.1-0.4$ & - & - & - \\
\hline Pyroxene (\%): & - & $\leq 5.0$ & - & - & - \\
\hline Morphology: & - & Subhedral to granular & - & - & - \\
\hline Size range $(\mathrm{mm})$ : & - & $0.05-0.4$ & - & - & - \\
\hline Opaque minerals (\%): & $\operatorname{Tr}$ & $\operatorname{Tr}$ & $\leq 1.4$ & - & - \\
\hline $\begin{array}{l}\text { Morphology: } \\
\text { Mold }\end{array}$ & Anhedral & Granular to globular & Euhedral to anhedral & - & - \\
\hline Size range $(\mathrm{mm})$ : & $\leq 0.02$ & $\leq 0.03$ & $0.01-0.025$ & - & - \\
\hline Spinel (\%): & - & - & - & - & - \\
\hline Morphology: & - & - & - & - & - \\
\hline Size range $(\mathrm{mm})$ : & - & - & - & - & - \\
\hline Mesostasis (\%) & $\leq 65$ & $\leq 85.5$ & $\leq 72.2$ & - & - \\
\hline Texture: & Subvariolitic (sheaf-spherulitic) & Sheaf-spherulitic to intersertal & Sheaf-spherulitic to intersertal & - & - \\
\hline
\end{tabular}

Notes: * = descriptions for Hole 1032A are based on macroscopic studies only; no thin sections were made for this hole because of time restrictions. $\mathrm{Tr}=$ trace amount. $-=$ not observed. 
within the Buried Basement sites. Table 7 lists the phenocryst and groundmass mineral modal abundances within each sample analyzed. The petrology of the Buried Basement basalts will be discussed in order of rock-type abundance. Secondary mineralogy caused by hydrothermal alteration will be discussed in full in "Basement Alteration" (below).

\section{Aphyric Pillow Basalt}

Aphyric pillow fragments were recovered from Hole 1031A and were designated as Unit 1a (Table 6). The presence of glassy, chilled margins on some of the fragments, along with the variolitic to subvariolitic textures within the rock fragments, permitted the structure of the subunit (i.e., 1a) to be established, with some degree of certainty.

The pillow basalt examined from Hole 1031A (Sample 1681031A-6X-1 [Piece 6, 24-28 cm]) contains subhedral to skeletal plagioclase $(0.4 \% ; 0.6-1.0 \mathrm{~mm}$; average $0.6 \mathrm{~mm})$, subhedral to anhedral pyroxene $(0.2 \% ; 0.6-0.6 \mathrm{~mm}$; average $0.35 \mathrm{~mm})$, and euhedral olivine $(0 \%$ left; $0.3-0.5 \mathrm{~mm}$; point counting indicates an original abundance of $\leq 2 \%)$. The rock is characterized by a sheaf-spherulitic to intersertal and microglomeroporphyritic texture. Plagioclase forms elongate laths and stubby crystals and occurs singly as well as within bimineralic glomeroporphyritic clots (plagioclase + pyroxene). Pyroxene phenocrysts are generally restricted to the glomeroporphyritic clots, but they are also found attached to single plagioclase laths. All olivine has been replaced by secondary clays (celadonite + iddingsite) and occurs as solitary crystals.

The groundmass mineralogy consists of microlites and microlaths of plagioclase, pyroxene, olivine, and primary magmatic opaque sulfides \pm oxides. Groundmass plagioclase $(0.05-0.5 \mathrm{~mm} ; \leq 11 \%)$ forms euhedral to skeletal microlaths and quench crystals that are distributed randomly throughout the mesostasis. These either occur singly or in association with microlites to microcrysts of pyroxene, which form 0.1-0.3 mm euhedral to anhedral crystals. Euhedral to granular opaque sulfides (pyrite \pm pyrrhotite; $0.0025-0.1 \mathrm{~mm}$ ) are disseminated throughout the groundmass.

All aphyric basalts are vesicular; Sample 168-1031A-6X-1 (Piece $6,24-28 \mathrm{~cm}$ ) contains $1.6 \%$ round to irregular gas vesicles, which are either completely filled by celadonite + iddingsite \pm saponite within the alteration halo or empty to finely lined by colorless zeolites within the interior of the rock.

\section{Sparsely to Moderately Phyric Pillow Basalts}

Sparsely to moderately phyric pillow basalts from Holes 1028A and 1029A were sampled. The rocks are aphanitic and characterized by a subvariolitic to intersertal texture; basalts from Hole 1029A are also characterized by a glomeroporphyritic texture. Slight variations occur within the phenocryst and groundmass mineral assemblages and abundances, both within and between holes (Tables 6, 7).

The pillow basalt from Hole 1028A is moderately phyric, containing phenocrysts of plagioclase $(\leq 4.6 \%)$, olivine $(0.2 \%-0.6 \%$; point counting indicates an original abundance of $0.8 \%-1.8 \%) \pm$ trace amounts of pyroxene. The plagioclase forms euhedral to subhedral and skeletal laths $(0.8-2.5 \mathrm{~mm})$ that commonly exhibit normal simple zoning. Although some plagioclase laths occur singly, the majority exist within monomineralic to polymineralic glomeroporphyritic clots. Olivine forms $0.4-2.8 \mathrm{~mm}$ (average $1.0 \mathrm{~mm}$ ) euhedral to subhedral and skeletal crystals, which are partially to completely altered by secondary hydrothermal clays and talc. Olivine occurs as single crystals as well as within glomeroporphyritic clots. A trace amount of pyroxene was found in Sample 168-1028A-15X-7 (Piece 9, 75-79 $\mathrm{cm}$ ) in the form of solitary euhedral, fresh crystals (with some glass inclusions in the cores). Some pyroxene was also present in a poikilitic arrangement within plagioclase laths and altered olivine microcrysts.

The groundmass mineralogy in the moderately phyric basalts from Hole 1028A consists of microlaths, microlites, and quench crystals of plagioclase $(9 \%-18 \%)$, euhedral to skeletal microcrysts of olivine (1.4-3.4\%; original abundances were $1.8 \%-4 \%)$, and trace amounts of primary magmatic opaque sulfides and oxides, all set within a subvariolitic (sheaf-spherulitic to honeycomb) to intersertal mesostasis. The plagioclase microcrysts $(0.05-0.8 \mathrm{~mm}$; average 0.3 $\mathrm{mm}$ ) occur singly as well as within stellate clusters, and in some sections they exhibit a subparallel to pilotaxitic texture. Microcrysts of olivine $(0.05-0.6 \mathrm{~mm}$; average $0.2 \mathrm{~mm})$ occur singly and within microclusters associated with plagioclase. The majority of groundmass olivine is fresh, although some microcrysts exhibit partial to complete replacement by secondary clays \pm talc. The primary magmatic opaque sulfides and oxides are disseminated throughout the mesostasis, forming small $(\leq 0.02 \mathrm{~mm})$, granular, solitary grains. The mesostasis (original abundances vary from $72 \%$ to $84 \%$ ) is massive to cryptocrystalline and characterized by a sheaf-spherulitic texture. It exhibits patchy alteration $(5 \%-7 \%)$, replaced by secondary hydrothermal clays (saponite \pm celadonite) and talc.

The pillow basalt from Hole 1029A is sparsely to moderately phyric, containing euhedral to subhedral and skeletal plagioclase $(1.6 \%-$ $2.4 \% ; 0.5-1.6 \mathrm{~mm})$ as well as euhedral to subhedral olivine $(0.4-0.6$ $\mathrm{mm}) \pm$ a trace amount of euhedral pyroxene $(0.4-0.8 \mathrm{~mm})$. As with samples from Hole 1028A, the plagioclase phenocrysts commonly exhibit simple zoning and are present as single crystals and within glomeroporphyritic clots (associated with phenocrysts and microcrysts of pyroxene \pm olivine). Olivine phenocrysts from Hole 1029A, however, are different than those from Hole 1028A, having been completely replaced by secondary granular saponite \pm celadonite. Although no fresh olivine occurs within these rocks, point counting indicates $0.2 \%-0.6 \%$ olivine was originally present. The pyroxene phenocrysts from Hole 1029A occur singly but are more commonly associated with either single plagioclase laths or located within glomeroporphyritic clots.

The groundmass mineralogy consists of euhedral to anhedral microlites, microlaths, and quench crystals of plagioclase $(\leq 6.6 \%$; $0.05-0.5 \mathrm{~mm})$; euhedral to skeletal microcrysts of olivine $(0.2 \%$ originally present, now replaced by secondary granular saponite \pm fibrous

Table 7. Modal mineral abundances for all thin-section analyses conducted on samples from Holes 1028A, 1029A, and 1031A.

\begin{tabular}{|c|c|c|c|c|c|c|c|c|c|c|c|}
\hline \multirow[b]{2}{*}{ Sample } & \multirow[b]{2}{*}{ Structure } & \multicolumn{3}{|c|}{ Phenocrysts } & \multicolumn{4}{|c|}{ Groundmass } & \multicolumn{2}{|c|}{ Vesicles } & \multirow{2}{*}{$\begin{array}{l}\text { Secondary } \\
\text { alteration } \\
(\%)\end{array}$} \\
\hline & & $\begin{array}{l}\text { Olivine }^{\mathrm{a}} \\
(\%)\end{array}$ & $\begin{array}{c}\text { Clinopyroxene } \\
(\%)\end{array}$ & $\begin{array}{c}\text { Plagioclase } \\
(\%)\end{array}$ & $\begin{array}{l}\text { Olivine }^{\mathrm{a}} \\
(\%)\end{array}$ & $\begin{array}{c}\text { Clinopyroxene } \\
(\%)\end{array}$ & $\begin{array}{c}\text { Plagioclase } \\
(\%)\end{array}$ & $\begin{array}{c}\text { Mesostasis }^{\mathrm{b}} \\
(\%)\end{array}$ & $\begin{array}{l}\text { Gas } \\
(\%)\end{array}$ & $\begin{array}{c}\text { Segregation } \\
(\%)\end{array}$ & \\
\hline 1028A-15X-7 (Piece 6, 47-51 cm) & Pillow basalt & 1.8 & - & 4.0 & 4.0 & - & 18 & 71.8 & 0.4 & 0.2 & 10.2 \\
\hline 1028A-15X-7 ((Piece 9, 75-79 cm) & Pillow basalt & 0.8 & $\operatorname{Tr}$ & 4.6 & 1.8 & - & 9.2 & 83.4 & $\operatorname{Tr}$ & - & 5.2 \\
\hline $1029 \mathrm{~A}-25 \mathrm{X}-3$ (Piece $12,83-87 \mathrm{~cm})$ & Pillow basalt & 0.2 & 2.4 & - & 0.2 & 4.6 & 6.6 & 85.4 & 0.6 & - & 1.2 \\
\hline 1029A-25X-4 (Piece 3, 18-21 cm) & Pillow basalt & 0.6 & $\operatorname{Tr}$ & 1.6 & 0.2 & 5.0 & 6.4 & 84.0 & 2.2 & $\operatorname{Tr}$ & 1.0 \\
\hline 1031A-6X-1 (Piece 6, 24-28 cm) & Pillow basalt & 2.0 & 0.2 & 0.4 & - & 9.6 & 11.2 & 75.6 & 1.6 & - & 5.0 \\
\hline
\end{tabular}

Notes: Massive ferrobasalts are classified according to whole-rock geochemistry. $-=$ not observed. ND $=$ not determined individually; counted as mesostasis. Tr $=$ trace amount. ${ }^{a}$ Olivine abundances represent the original abundance before alteration.

${ }^{\mathrm{b}}$ Mesostasis abundances include any glass present in the thin section. 
celadonite \pm iddingsite; $0.1-0.4 \mathrm{~mm}$ ); subhedral to granular microcrysts of pyroxene $(4.6 \%-5 \% ; 0.05-0.4 \mathrm{~mm})$; and trace amounts of granular to globular pyrite $(0.005-0.5 \mathrm{~mm})$, all set within a subvariolitic mesostasis. The plagioclase microlaths form large microglomeroporphyritic clots $(\leq 6 \mathrm{~mm})$ associated with pyroxene microcrysts, whereas the plagioclase quench crystals and microlites occur as single crystals. Olivine generally occurs as solitary crystals within the mesostasis, with a few pseudomorphed microcrysts also located at the edges of some microglomeroporphyritic clots. Disseminated throughout the mesostasis are the granular to globular pyrite grains; perfectly spherical globules $(\leq 0.02 \mathrm{~mm})$ of pyrite may represent drops that were immiscible within the magma. The mesostasis, which typically represents between $84 \%-85 \%$ of the sparsely to moderately phyric pillow basalts from Hole 1029A, has undergone only limited alteration $(\leq 1 \%)$ to secondary saponite \pm celadonite and has a patchy texture varying from sheaf-spherulitic to plumose and honeycomb.

All sparsely to moderately phyric pillow basalts from Holes $1028 \mathrm{~A}$ and $1029 \mathrm{~A}$ are vesicular, containing a trace amount to $2.2 \%$ round to irregular gas vesicles $(0.05-0.6 \mathrm{~mm}), 0.2 \%$ segregation vesicles $(0.05-0.35 \mathrm{~mm})$, and a trace amount of irregular cavities $(\leq 0.6$ $\mathrm{mm})$. The gas vesicles are either empty or partially to completely filled by secondary hydrothermal saponite \pm iddingsite \pm celadonite, whereas the segregation vesicles are filled with massive mesostasis material, with some also containing an inner gas bubble, filled with secondary saponite. The irregular cavities are generally concentrated near the rim of the piece and are partially to completely filled by the same secondary phases as the gas vesicles. The moderately phyric pillow basalts from Hole 1028A are slightly to moderately altered $(5 \%-10 \%)$, whereas those from Hole 1029A are slightly altered $(\sim 0.1 \%$ alteration $)$.

\section{Basement Alteration}

Secondary alteration with variable intensity affects all igneous rocks recovered from Sites 1028, 1029, 1031, and 1032 (Table 8). Secondary minerals occur as (1) vesicle or cavity linings or fillings; (2) coatings, fracture fillings, and veins; (3) replacement of phenocrysts and microphenocrysts; and (4) patches within mesostasis. The following sections describe the alteration minerals, as well as specific alteration characteristics of the rocks such as the alteration intensity, halos, and veins.

\section{Secondary Minerals}

The following secondary minerals were identified by means of hand specimen observation, optical characteristics in thin section, and powder X-ray diffraction (XRD): clay minerals (including talc), iddingsite, carbonates, sulfides, and zeolites.

\section{Clay Minerals}

Clay minerals are ubiquitous and are the most abundant secondary products, exhibiting all four modes of occurrence (in vesicles, in veins, as mineral replacements, and in mesostasis). Clay minerals were determined optically following the same criteria as used throughout Leg 168 (see the "Hydrothermal Transition Transect" chapter, this volume). Two X-ray diffractograms of a clay vein mineral from Hole 1029A, one air dried and another glycolated, provide confirmation of the presence of celadonite, a dioctahedral illite group (or mica group) clay mineral $\left(\mathrm{d}_{001}=10.9 \AA, \mathrm{d}_{001}\right.$ [glycolated] $=10.9$ $\AA, \mathrm{d}_{060}=1.523 \AA$ ).

Saponite is a common clay that has been identified at all sites. It occurs as cryptocrystalline granular or fibrous aggregates, varying in color from green to greenish blue, grayish green, and pale blue in hand specimens and from pale brown (most commonly) to yellowish, brownish green and olive green in thin section. In weakly altered samples, saponite lines vesicles in thin layers, whereas in more heavily altered samples, it may fill vesicles completely. Saponite, the most common mineral observed to alter olivine phenocrysts or microphenocrysts, occurs alone or with talc or calcium carbonate. Saponite also occurs as a vein mineral, alone or with other minerals, and as a replacement of mesostasis.

Celadonite forms cryptocrystalline granular or fibrous aggregates and is bright green in both hand specimen and thin section. It forms vesicle linings or complete fillings, and veins, and it is commonly intergrown with other minerals (e.g., saponite, iddingsite, or yellow clay). Celadonite is characteristic (along with iddingsite and/or yellow clay, and hematite) of an oxidative style of alteration (see the "Hydrothermal Transition Transect" chapter, this volume).

Talc

Talc occurs as a replacement (with saponite) of olivine in core from Hole 1028A. The mineral varies from fibrous and pale tan to micaceous and colorless, with both varieties having very high birefringence.

\section{Iddingsite and Yellow Clay}

Iddingsite is a mixture of clay mineral(s) and Fe oxyhydroxide and has a characteristic red-orange or reddish brown color both in hand specimen and thin section. It occurs as irregular patches, replacing mafic minerals or lining/filling vesicles and veins, and is often associated with celadonite.

Yellow clay is common in and unique to the pillow basalts from Hole 1032A. It occurs in association with celadonite, which is typically how iddingsite was observed at the other sites. Without thin sections, the identification of this clay is not possible. It may be a variety of an iddingsite-type phase.

\section{Calcium Carbonate}

Carbonate occurs in veins at Sites 1028 and 1032 and as a replacement of olivine phenocrysts along with saponite at Site 1032. Vein material from Section 168-1028A-15X-7 was determined by XRD to be pure aragonite. Much of the carbonate vein material from Site 1032 appears to be aragonite on the basis of crystal habit.

\section{Sulfide Minerals}

Secondary sulfides are common at the Buried Basement sites. At Hole 1029A, some vesicles contain clay linings followed by drusy clusters of pyrite. At Hole 1032A, sulfides occur as vesicle linings followed by clay and as vein minerals with dark green clay or carbonate. Fine interstitial sulfides (pyrite and pyrrhotite, by reflected light

Table 8. Modal point-count data for secondary minerals in thin sections from Sites 1028, 1029, and 1031.

\begin{tabular}{|c|c|c|c|c|c|c|c|c|c|}
\hline Sample & Structure & $\begin{array}{c}\text { Total } \\
\text { alteration } \\
(\%)\end{array}$ & $\begin{array}{c}\text { Saponite } \\
(\%)\end{array}$ & $\begin{array}{c}\text { Celadonite } \\
(\%)\end{array}$ & $\begin{array}{c}\text { Iddingsite } \\
(\%)\end{array}$ & $\begin{array}{c}\text { Hematite } \\
(\%)\end{array}$ & $\begin{array}{c}\text { Pyrite/ } \\
\text { Pyrrhotite } \\
(\%)\end{array}$ & $\begin{array}{l}\text { Talc } \\
(\%)\end{array}$ & $\begin{array}{c}\text { Zeolite } \\
(\%)\end{array}$ \\
\hline 1028A-15X-7 (Piece 6, 47-51 cm) & Pillow basalt & 10 & 6.6 & 2 & 0.2 & 0 & $\operatorname{Tr}$ & 1.2 & 0 \\
\hline 1028A-15X-7 (Piece 9, 75-79 cm) & Pillow basalt & 5.2 & 4.2 & 0.8 & 0 & 0 & $\operatorname{Tr}$ & 0.2 & $\operatorname{Tr}$ \\
\hline 1029A-25X-3 (Piece 12, 83-87 cm) & Pillow basalt & 1 & 0.8 & 0.2 & $\operatorname{Tr}$ & $\operatorname{Tr}$ & $\operatorname{Tr}$ & 0 & 0 \\
\hline 1029A-25X-4 (Piece $3,18-21 \mathrm{~cm}$ ) & Pillow basalt & 1.2 & 1 & 0.2 & $\operatorname{Tr}$ & 0 & $\operatorname{Tr}$ & 0 & 0 \\
\hline 1031A-6X-1 (Piece 6, 24-28 cm) & Pillow basalt & 5 & 1 & 0.8 & 3 & 0 & $\operatorname{Tr}$ & 0 & 0.2 \\
\hline
\end{tabular}

Note: $\operatorname{Tr}=$ trace amount 
microscopy) from Holes 1029A, 1031A, and 1032A are observed preferentially in millimeter-scale bands that parallel the inner edge of oxidative alteration halos.

\section{Zeolites}

Trace amounts of zeolite occur in vesicles, in veins, and as replacements for phenocrysts. In samples from Hole 1029A, drusy, botryoidal, and clear zeolites occur with saponite in vesicles and veins. For Holes 1031A and 1032A, as well, zeolite occurs with saponite in veinlets that pass through glassy chilled margins. The thin section from Hole 1031A contains zeolite that fills vesicles and replaces mafic phenocrysts.

\section{Alteration Intensity}

The amount of alteration determined by point counting the secondary minerals in thin sections varies from $1.0 \%$ to $10.0 \%$. Larger variations are apparent in hand specimen, with visual estimates of secondary phases in alteration halos commonly around $40 \%$. Olivine alteration is typically a sensitive petrographic indicator of alteration intensity. However, at the Buried Basement Transect sites, olivine replacement varies from incomplete in samples from Hole 1028A (thin sections have $5.2 \%$ and $10.2 \%$ secondary minerals) to complete at the other three Buried Basement sites (thin sections from Hole 1029A have $1.0 \%$ and $1.2 \%$ secondary minerals, and the thin section from Hole $1031 \mathrm{~A}$ has $5.0 \%$ secondary minerals). It is possible that variations in temperature, time, and ease of fluid access combine to cause variations in alteration intensity.

The intensity of glass alteration is generally quite high at the Buried Basement sites, particularly at Hole 1032A. Fresh glass is partially altered to clays, zeolites, and variable oxidation products (celadonite and iddingsite), with these secondary products commonly concentrated in the variolitic zones immediately beneath the glassy margins as well.

\section{Alteration Halos}

Alteration halos are common at all the Buried Basement sites. They are reported in the alteration log (Appendix C on CD-ROM, back pocket). These halos, 1-15 $\mathrm{mm}$ wide, appear in hand specimen as dark borders on rock pieces that may be stained with orange or yellow. Alteration halos are distinguished by the presence of completely filled vesicles, in contrast to empty or saponite-lined and -filled vesicles in the gray, nonhalo portion of the rock. The vesicle filling material is clay, commonly iddingsite and/or celadonite. Two rocks from Hole 1031A contain very sharply defined double halos that consist of a dark green to green-yellow outer halo and a gray inner one (5-6 $\mathrm{mm}$ and 3-4 $\mathrm{mm}$ wide, respectively). The outer halo has vesicles filled by bright green and yellow clays (celadonite and iddingsite/yellow clay), whereas the inner halo appears to be a bleached zone. A band of fine interstitial sulfide minerals occurs within the gray inner halo at the border adjacent to the outer green-yellow halo.

\section{Vesicle Fillings}

Most vesicles are either lined or completely filled by secondary minerals. Most commonly, vesicles are lined by one or more texturally and mineralogically different clays, with or without accessory pyrite or zeolite. Vesicle fillings vary systematically depending on whether the vesicles are in the alteration halos, transitional zones, or the gray rock interiors.

Pillow basalts from Site 1028 contain vesicles that are partially or completely filled by a dark green-blue clay mineral. Thin sections contain saponite \pm celadonite \pm iddingsite vesicle fillings. At Site 1029 , pillow basalts have vesicles lined by saponite in the gray rock interiors and filled completely within alteration halos with the filling sequence celadonite to iddingsite to saponite. Hole 1031 A pillow basalts have vesicles filled completely in alteration halos (with the general sequence celadonite to iddingsite to saponite). In the interior gray rock, however, vesicles are empty or partially filled with clear zeolite material (forming radial splays of acicular and columnar crystals). Most vesicles from Hole 1032A are almost completely filled by pale gray-green clay (probably saponite) in rock interiors and by mixtures of bright green and yellow clays (probably celadonite and iddingsitelike material) in alteration halos.

\section{Veins}

Several vein types were noted and individual occurrences are recorded in the vein log (Appendix D on CD-ROM, back pocket). At Site 1028 , the pillow basalts contain veinlets filled by bright green clay (celadonite), as well as several fibrous carbonate + clay veins. The maximum width is $2 \mathrm{~mm}$. At Site 1029, there are millimeter-scale veins with green and orange clays (celadonite + iddingsite) that have 1 -mm halos. There are also dark green veins $( \pm$ sulfide) and zeolite + clay veins associated with glass rims.

Site 1031 samples have scarce celadonite + iddingsite veins, commonly on the outer surfaces of rocks, as well as a single saponite + zeolite vein associated with altered glass. At Site 1032, numerous veins occur, including those with dark green clay \pm sulfide, light green clay, bright green and orange and yellow clay, fibrous carbonate \pm pyrite, and pale blue clay + clear zeolite associated with altered glass.

Tiny veins only about a tenth of a millimeter wide clearly represent filled fractures that must have helped allow fluid access to the fresh rocks. One problem in interpreting the role of fractures is knowing what the fracture aperture was at any time in the past: Does a vein ever represent the previous existence of an open fracture having the same aperture as the present-day vein width? One recurring observation from the Buried Basement sites bears on this question: the nature of clay veins with mineralogy that varies along strike. These tiny veins cut across alteration halos and extend into the interior gray rock. The halos are characterized by zonation in the mineralogy of vesicle fills, from orange-yellow iddingsite-type clays at the outside, to bright green celadonitic clays at the inside. The gray rock contains saponite or carbonate + sulfide in vesicles. Veins that cut across this sequence have mineralogy that varies along strike, from orangeyellow clay, to light green clay, to dark green clay with pyrite, and finally, to carbonate. The sequence matches the sequence of zoned secondary minerals in the groundmass; however, along the vein the zones extend several halo widths into the rock interior. Commonly, an alteration halo that parallels the rock edge will deflect toward the center of the rock if a vein is present. These observations suggest that the veins represent paths of fluid access into rocks, although they do not behave as completely open pathways. Instead, fluids simply diffuse along the fractures at a rate greater than they can diffuse through unfractured rock.

\section{Summary}

Basalts from the Buried Basement Transect represent aphyric to moderately phyric pillow basalts that have been altered by hydrothermally modified seawater at low temperatures, probably less than $100^{\circ} \mathrm{C}$, and possibly at temperatures no higher than the present basement temperatures of $40^{\circ}-58^{\circ} \mathrm{C}$. All of the sites exhibit varying degrees of alteration, including varying degrees of oxidative alteration that required significant open seawater circulation early in the history of these basalts. Subsequent alteration effects include calcium carbonate \pm sulfide veining at Sites 1028 and 1032 and saponite \pm pyrite alteration at all of the Buried Basement Transect sites. This stage of 
alteration may represent the product of relatively closed hydrothermal circulation similar to that taking place at the present time at the Buried Basement Transect sites.

\section{AGE PROFILES Calcareous nannofossils}

Nannofossils are common to abundant in hemipelagic mud layers in Holes 1028A, 1029A, 1030B, 1031A, and 1032A but are very rare or absent in turbidite beds. Nannofossils are generally well preserved (with slight dissolution) in most sediments and moderately to strongly dissolved or overgrown in a few samples. Nannofossil age assignments are based mainly on samples in which nannofossils are well preserved.

A Quaternary nannofossil assemblage was found in these holes (Table 9). In Hole 1028A, the top of Reticulofenestra asanoi was not recognized, probably because of poor recovery between $114.2 \mathrm{mbsf}$ and 123.8 mbsf. In Hole 1029A, the top of Gephyrocapsa caribbeanica was not determined because nannofossils are nearly absent in sediments between the base of acme Emiliania huxleyi and the base of $E$. huxleyi, possibly because of strong dilution of turbidite materials. A few specimens of Helicosphaera sellii were observed at $219.07 \mathrm{mbsf}$ in this hole. This was taken as $H$. sellii's last occurrence because this datum in this hole can be correlated to the same datum at Sites 1026 and 1027 (see "Age Profiles" section, Rough Basement Transect chapter, this volume). In Hole 1032A, only two nannofossil datums - the base of G. caribbeanica and the top of G. lumina-were used because there was no core recovery above $184.5 \mathrm{mbsf}$ and nannofossils are absent in most sediments below that depth. The first sample recovered (at $184.5 \mathrm{mbsf}$ ) from Hole 1032A contains abundant Pseudoemiliania lacunosa, which suggests that this sediment is below the top of P. lacunosa and thus is older than $0.46 \mathrm{Ma}$. The absence of $H$. sellii within this hole indicates an age of the basal sediment younger than $1.55 \mathrm{Ma}$.

Figure 8 shows age/depth plots of nannofossil datums for these five holes. Generally, sedimentation rates and the time duration of the hiatus between basal sediments and basement increase toward the east.

\section{Magnetostratigraphy}

Paleomagnetic measurements were made on sediment cores recovered from Holes 1028A, 1029A, 1030B, 1031A, and 1032A to determine the magnetostratigraphy for each of the sections drilled. These data were then combined with the micropaleontological data to produce a sedimentation rate/age profile for the sections. The age of the basement over this transect is inferred from magnetic lineations to be between 1.1 and $2.6 \mathrm{Ma}$.

The natural remanent magnetization (NRM) was measured for all APC cores. The NRM results show very steep positive inclinations $\left(>75^{\circ}\right)$ throughout the cores. This steep normal polarity NRM has been observed through all Leg 168 cores and is interpreted to be a ubiquitous drilling-induced overprint. The cores were demagnetized in a $20-\mathrm{mT}$ alternating field to remove the drilling overprint and permit interpretation of the remanent magnetization polarity sequence recorded in the sediments. In the absence of any core orientation and, hence, declination control, the inclination data were used as the primary indicator of magnetic polarity.

Except for the upper $184.5 \mathrm{~m}$ of Hole 1032A, which was not cored, nearly continuous core data are available for sites of the Buried Basement Transect, from the seafloor to the basement contact. Short intervals with no data occur where severe drilling disturbance was recognized, either in the form liquefied sand units or biscuited sediments suspended in more than $50 \%$ slurry.

Plots of inclinations after $25 \mathrm{mT}$ demagnetization (Figs. 9-11) show that the cores from each site have almost exclusive positive magnetic polarities in the upper portions. Hole 1028A shows scattered positive inclinations $\left(0^{\circ}\right.$ to $\left.90^{\circ}\right)$ in the top $10 \mathrm{~m}$ of the core (Fig. 9 ); this scatter is probably associated with coring disturbance. The very steep positive inclinations observed from there to $115 \mathrm{mbsf}$ at Site 1028A are interpreted as Brunhes normal polarity. An abrupt transition from normal to reversed magnetization at $115 \mathrm{mbsf}$ is interpreted to be the Brunhes/Matuyama boundary.

The magnetostratigraphy of Hole 1029A is very similar to that of Hole 1028A (cf. Figs 9, 10). The Brunhes/Matuyama boundary $(0.78$ $\mathrm{Ma}$ ) is identified at $180 \mathrm{mbsf}$ and correlated well with the nannofossil stratigraphy, which infers an age of $0.78 \mathrm{Ma}$ at $160 \mathrm{mbsf}$ (Fig. 8). The Jaramillo event may be represented by positive polarities in the short interval from 198 to 208 mbsf.

Site 1032 is located on basement that is at the Matuyama/Gauss polarity boundary. Because of poor recovery, a complete magnetostratigraphy of the Brunhes/Matuyama boundary is not possible. By comparison with magnetic data from Hole 1029A and the nannofossil data at Site 1032 the Brunhes/Matuyama boundary is inferred to occur between 210 and $230 \mathrm{mbsf}$ in an interval of no magnetic data. The base of the Jaramillo event at $1.07 \mathrm{Ma}$ is placed at $275 \mathrm{mbsf}$, also with the aid of nannofossil data (Fig. 8). This stratigraphic position, only $20 \mathrm{~m}$ above the contact with the 2.62-Ma basement, indicates a significant hiatus between crustal formation and the onset of sedimentation.

A shallow buried ridge buried locally by about $40 \mathrm{~m}$ of sediment was drilled at Sites 1030 and 1031. The magnetic reversal sequences are very similar, with the Brunhes/Matuyama boundary indicated by abrupt transitions from normally to reversely magnetized sediment at 30 mbsf in Hole 1031A (Fig. 11) and slightly deeper in Hole 1030B. The combination of the magnetic and nannofossil stratigraphic data again suggest a hiatus between the formation of the 1.43-Ma crust at this site and the beginning of significant sediment accumulation. The occurrence of this hiatus across the full Buried Basement Transect is apparent in Figure 12, which summaries the magnetic data from all sites.

Table 9. Stratigraphic list of calcareous nannofossil events for Buried Basement Holes 1028A, 1029A, 1030B, 1031A, and 1032A.

\begin{tabular}{|c|c|c|c|c|c|c|c|c|c|c|c|}
\hline \multirow[b]{2}{*}{$\begin{array}{c}\text { Nannofossil } \\
\text { event }\end{array}$} & \multicolumn{2}{|c|}{ Hole 1028A } & \multicolumn{2}{|c|}{ Hole 1029A } & \multicolumn{2}{|c|}{ Hole 1030B } & \multicolumn{2}{|c|}{ Hole 1031A } & \multicolumn{2}{|c|}{ Hole 1032A } & \multirow[b]{2}{*}{$\begin{array}{l}\text { Age } \\
(\mathrm{Ma})\end{array}$} \\
\hline & $\begin{array}{l}\text { Core, section, } \\
\text { interval }(\mathrm{cm})\end{array}$ & $\begin{array}{l}\text { Depth } \\
\text { (mbsf) }\end{array}$ & $\begin{array}{l}\text { Core, section, } \\
\text { interval }(\mathrm{cm})\end{array}$ & $\begin{array}{l}\text { Depth } \\
\text { (mbsf) }\end{array}$ & $\begin{array}{l}\text { Core, section, } \\
\text { interval }(\mathrm{cm})\end{array}$ & $\begin{array}{l}\text { Depth } \\
\text { (mbsf) }\end{array}$ & $\begin{array}{l}\text { Core, section, } \\
\text { interval }(\mathrm{cm})\end{array}$ & $\begin{array}{l}\text { Depth } \\
\text { (mbsf) }\end{array}$ & $\begin{array}{l}\text { Core, section, } \\
\text { interval }(\mathrm{cm})\end{array}$ & $\begin{array}{l}\text { Depth } \\
\text { (mbsf) }\end{array}$ & \\
\hline B acme E. huxleyi & $4 \mathrm{H}-5,106$ & 29.76 & $4 \mathrm{H}-5,35$ & 29.85 & $2 \mathrm{H}-5,60$ & 10.6 & $1 \mathrm{H}-3,55$ & 3.55 & & & 0.09 \\
\hline T G. caribbeanica & $7 \mathrm{H}-6,49$ & 59.19 & & & $3 \mathrm{H}-4,40$ & 18.40 & $1 \mathrm{H}-5,73$ & 6.73 & & & 0.22 \\
\hline B E. huxleyi & $8 \mathrm{H}-2,114$ & 63.34 & $9 \mathrm{H}-5,129$ & 78.29 & $4 \mathrm{H}-4,110$ & 28.60 & $2 \mathrm{H}-1,130$ & 10.10 & & & 0.28 \\
\hline T P. lacunosa & $11 \mathrm{H}-3,33$ & 92.53 & $14 X-4,16$ & 119.56 & $5 \mathrm{H}-2,44$ & 34.44 & $3 \mathrm{H}-1,65$ & 18.95 & & & 0.46 \\
\hline B G. caribbeanica & $12 \mathrm{H}-2,96$ & 101.16 & $19 X-2,24$ & 160.94 & & & $4 \mathrm{H}-2,124$ & 30.54 & $5 \mathrm{R}-4,8$ & 227.48 & 0.76 \\
\hline T R. asanoi & & & $22 X-7,55$ & 197.55 & & & $4 \mathrm{H}-\mathrm{CC}, 20$ & 37.93 & & & 0.90 \\
\hline B R. asanoi & $15 X-1,48$ & 124.28 & 23X-CC, 34 & 207.32 & & & & & & & 1.15 \\
\hline $\mathrm{T} G$. lumina & $15 X-5,80$ & 130.60 & $24 X-7,10$ & 216.30 & & & & & 10R-CC, 10 & 276.83 & 1.23 \\
\hline T H. sellii & & & $25 X-2,77$ & 219.07 & & & & & & & 1.55 \\
\hline T C. macintyrei & & & $25 X-3,22$ & 220.02 & & & & & & & 1.58 \\
\hline
\end{tabular}

Note: $\mathrm{B}=$ bottom, and $\mathrm{T}=$ top. 


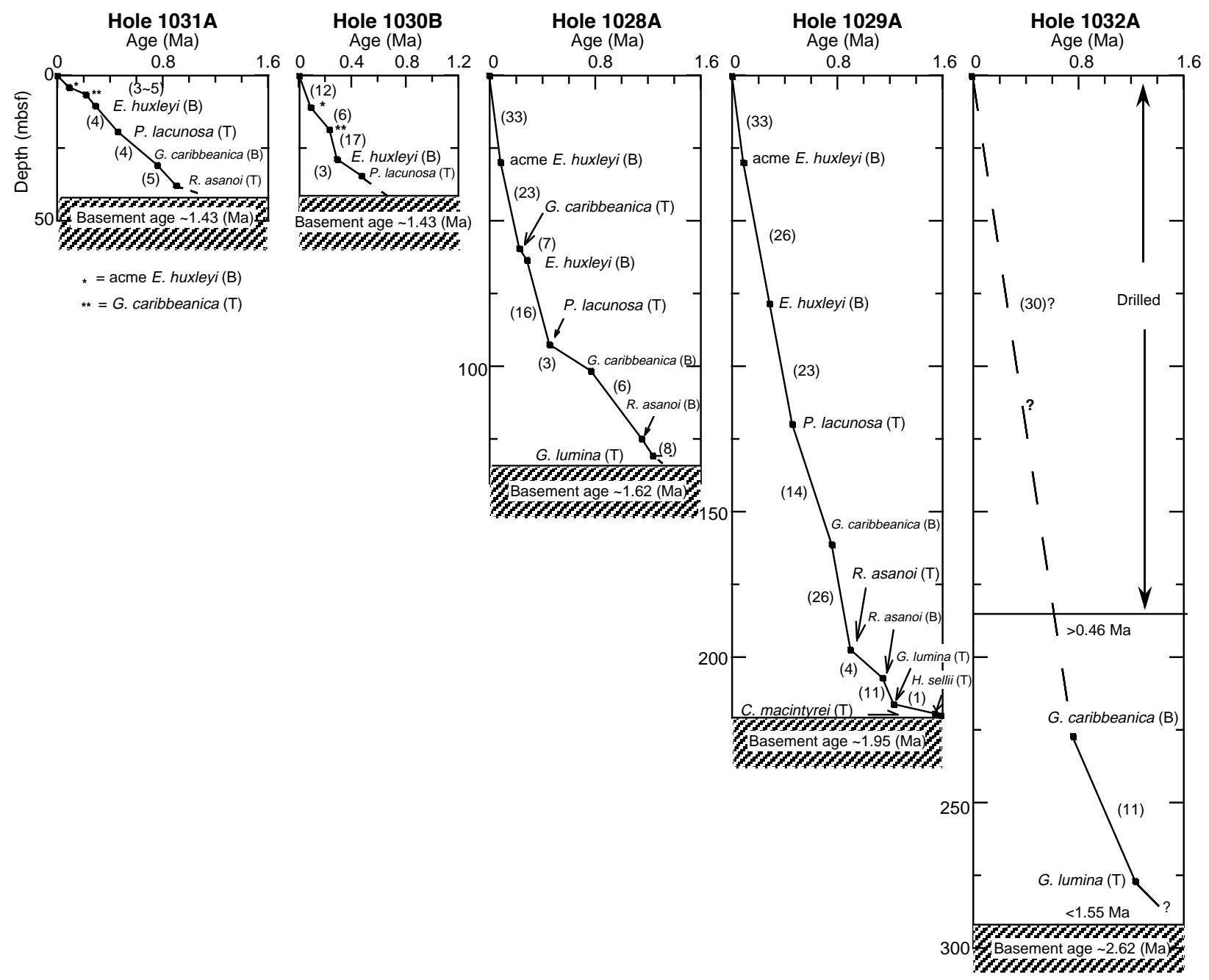

Figure 8. Age and depth correlation of nannofossil and paleomagnetic datums in Buried Basement Holes 1031A, 1030B, 1028A, 1029A, and 1032A.

\section{FLUID GEOCHEMISTRY}

Sites 1030 and 1031 were drilled on a buried basement ridge where previous work in 1990 using short cores had indicated that a high-chlorinity fluid was upwelling from depth (Wheat and Mottl, 1994). Site 1031 was drilled near the area cored in 1990, and Site 1030 was drilled about $1 \mathrm{~km}$ to the north. At both sites the pore-water profiles provide clear evidence of upward flow, exhibiting characteristic convex-upward shapes for less reactive chemical species, including chlorinity, magnesium, calcium, potassium, and phosphate (Figs. 13-15; Table 10). Highly reactive species are also affected. Alkalinity, for example, normally increases greatly in the upper part of the sediment column because of bacterial oxidation of organic matter utilizing sulfate as a reductant. At Site 1030, however, alkalinity increases only slightly before decreasing at greater depth, and at Site 1031 it decreases steadily with depth. The pore water is upwelling slightly faster than $2 \mathrm{~mm} / \mathrm{yr}$, based on comparison with the 1990 results as modeled by Wheat and Mottl (1994). Upwelling is slightly faster at Site 1031 than at Site 1030, as shown by a remarkable contrast in sulfate and especially ammonia between the two sites. This contrast results from a small shift in the balance between ammonia production and sulfate reduction by bacterial breakdown of organic matter, and displacement of ammonia-enriched and sulfate-depleted pore water by the upwelling of water from basement that is relatively ammonia poor and sulfate rich. Chlorinity at Sites 1030 and 1031 increases with depth to $564 \mathrm{mmol} / \mathrm{kg}$, about the concentration in bottom seawater during the last glacial maximum about $20 \mathrm{ka}$. Chlorinity remains elevated to the bottom of the sediment column. Chlorinity this high was seen during Leg 168 only at Site 1026, and then not within $85 \mathrm{~m}$ of basement. In particular it is much lower $(<550 \mathrm{mmol} /$ $\mathrm{kg}$ ) near basement at the adjacent sites, Site 1025 , only $6 \mathrm{~km}$ to the west, and Site 1028 , only $5 \mathrm{~km}$ to the east. This difference suggests that the waters upwelling from basement at Sites 1030 and 1031, which also have much lower magnesium and higher calcium than the adjacent sites, originate from a different source.

Sites 1028, 1029, and 1032 form an west-to-east transect east of the buried basement ridge where Sites 1030 and 1031 were drilled. Pore-water compositional profiles at the sites show typical features seen at other Leg 168 sites, including evidence for diagenesis of organic matter (decrease in sulfate and increase in alkalinity, ammonia, and phosphate within the upper part of the sediment column), mineral reactivity (minima in calcium, magnesium, and potassium), and diffusive exchange with altered seawater in basement (decrease in alkalinity, ammonia, phosphate, magnesium, sodium, chlorinity, and silica; and increase in sulfate, calcium, and potassium as basement is approached). The latter changes, especially the decrease in chlorinity near basement, provide unequivocal evidence that partially reacted seawater is flowing through basement at these sites. The inferred 


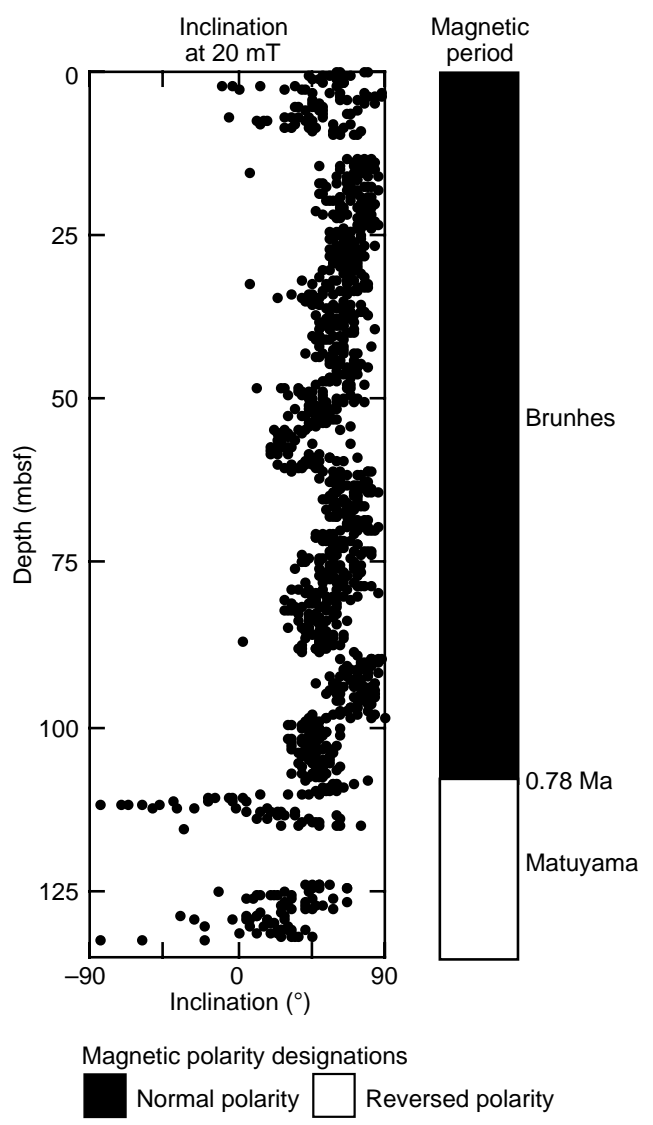

Figure 9. Inclination of remanent magnetization after 20-mT demagnetization for Hole 1028A. The Brunhes/Matuyama boundary is placed at $110 \mathrm{mbsf}$.

chlorinities of these basement waters are uniformly less than that of bottom seawater at the last glacial maximum, indicating that the residence time of the waters in basement is less than 20 k.y.

Combined with the Hydrothermal Transition Sites 1023, 1024, and 1025, the Buried Basement Sites 1028, 1029, and 1032 form a regular west-to-east progression in basement water composition for most chemical species, as inferred from the composition of the basal sediment pore water. As noted above, the water upwelling from basement at Sites 1030 and 1031 does not fit this pattern. For most species, basement water at the Rough Basement Sites 1026 and 1027 is similar to that at Site 1032; these are the three warmest sites, having temperatures at the top of basement of $62^{\circ}, 63^{\circ}$, and $57^{\circ} \mathrm{C}$, respectively. The simplest interpretation of these data is that bottom seawater enters basement through the sediment-free basement rock exposed within $18 \mathrm{~km}$ of the Juan de Fuca Ridge axis to the west. This seawater then flows steadily eastward through the upper basement, becoming progressively warmer and more altered as it goes. It has traveled at least as far as Site 1032, a distance of at least $57 \mathrm{~km}$ in less than 20 k.y. The Three Bare outcrops near the Rough Basement sites may provide an additional source of bottom seawater, possibly accounting for the somewhat lower chlorinity at Sites 1026 and 1027 vs. Site 1032. Piercing through the general eastward flow is the water upwelling at Sites 1030 and 1031. Its distinct composition suggests that this water comes from a different and possibly deeper hydrothermal system. This water is more altered than the basement water at the adjacent sites and its chlorinity is similar to that of bottom seawater at the last glacial maximum about $20 \mathrm{ka}$. Both features are consistent with this water having a longer residence time in basement than does the water in the shallower, eastward flowing system.

\section{ORGANIC GEOCHEMISTRY}

Organic geochemical analyses of sediments from Sites 1028, $1029,1030,1031$, and 1032 include measurements of volatile hydrocarbons, inorganic carbon, total carbon, sulfur, nitrogen, and hydrogen. Sediment samples from the last hole, 1032A, were analyzed at Stockholm University. The instrumentation and procedures are summarized in the "Methods" chapter (this volume).

\section{Volatile Hydrocarbons}

Headspace methane data are listed in Table 11 and shown in Figure 16. In sediment from Holes 1028A, 1030B, and 1031A, methane concentrations are close to background values and never exceed 10 ppm. Dissolved sulfate at these sites never drops below 2, 20, and 23 $\mathrm{mmol} / \mathrm{kg}$, respectively, precluding bacterial methanogenesis. Sites 1029 and 1032 have high methane concentrations that are generated by bacteria, as indicated by the dissolved sulfate profiles, which decrease to zero at intermediate depths at both sites. Volatile hydrocarbons other than methane are absent at all of these sites.

\section{Total Organic Carbon, Sulfur, Nitrogen, and Hydrogen Concentrations}

The result from NCHS analyses are listed in Table 12 on CDROM (back pocket). As explained in the "Hydrothermal Transition Transect" and "Rough Basement Transect" chapters, the NCHS analyzer was unable to measure sulfur correctly during Leg 168. The few nonzero values in Table 12 probably indicate higher sulfur concentrations in these samples than in the others, but the actual values should not be trusted.

Sedimentary nitrogen, hydrogen, and total organic carbon (TOC) are plotted in Figure 17. In Hole 1028A samples, TOC decreases slightly with depth, whereas hydrogen and nitrogen are nearly constant downhole. In Hole 1029A samples, TOC and nitrogen covary and decrease with depth. Hydrogen also covaries with the exception of one anomalously high value in the last core. In Hole 1031A, TOC, nitrogen, and hydrogen also covary. At all sites, TOC, hydrogen, and nitrogen values generally fall within the same ranges as at the Hydrothermal Transition and Rough Basement sites.

\section{Organic Matter Type}

In Figure 18, TOC is plotted against the total nitrogen content of the sediments. Most values fall within a region typical for marine organic matter. Average $\mathrm{C} / \mathrm{N}$ mole ratios are 9.6, 7.5, and 8.0 for Sites 1028, 1029, and 1031, respectively.

\section{PHYSICAL PROPERTIES}

Physical properties were measured continuously with the multisensor track (MST) and on discrete samples from cores recovered from Sites 1028, 1029, 1030, 1031, and 1032. The results are summarized in Figure 19. The data are separated into mud and sand lithologies based on the visual core descriptions. Averages, standard deviations, and the number of measurements are listed according to this separation in Table 13. Hole 1031A contained a single thin layer of sand, and no physical properties measurements were made in this interval. To assess a possible sampling bias, the total thickness of recovered sand relative to the thickness of the recovered section was compared to the number of measurements in sand relative to the total number of measurements (Table 14).

Some physical properties measurements at this site appear to be affected by core disturbances associated with the switch from APC to XCB coring at 108.2 and 109.0 mbsf in Holes 1028A and 1029A, re- 


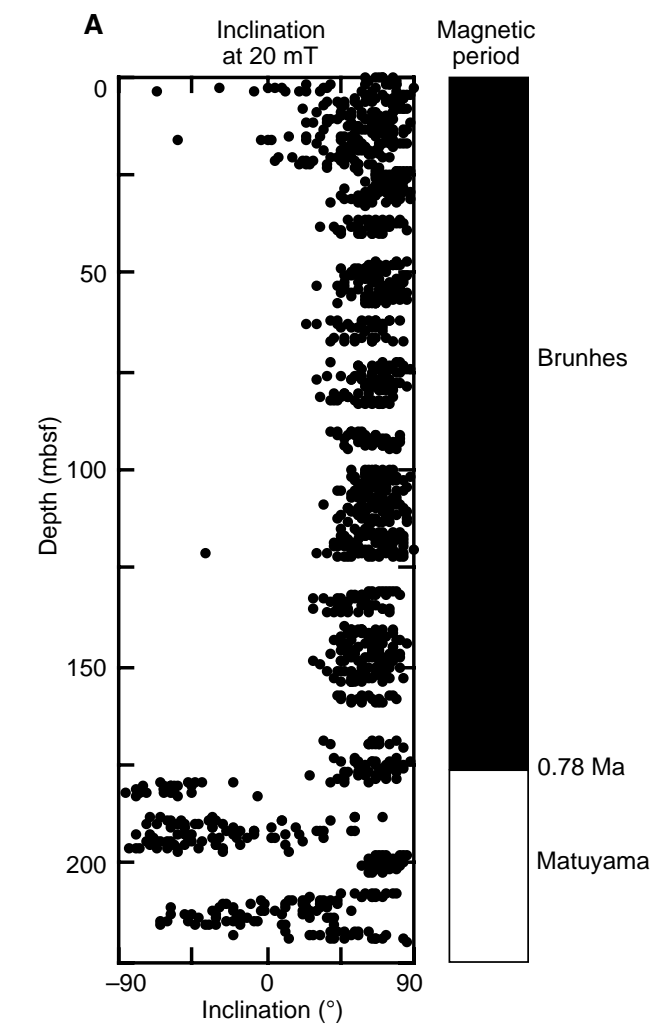

Magnetic polarity designations

Normal polarity $\square$ Reversed polarity $\square$ Unknown polarity

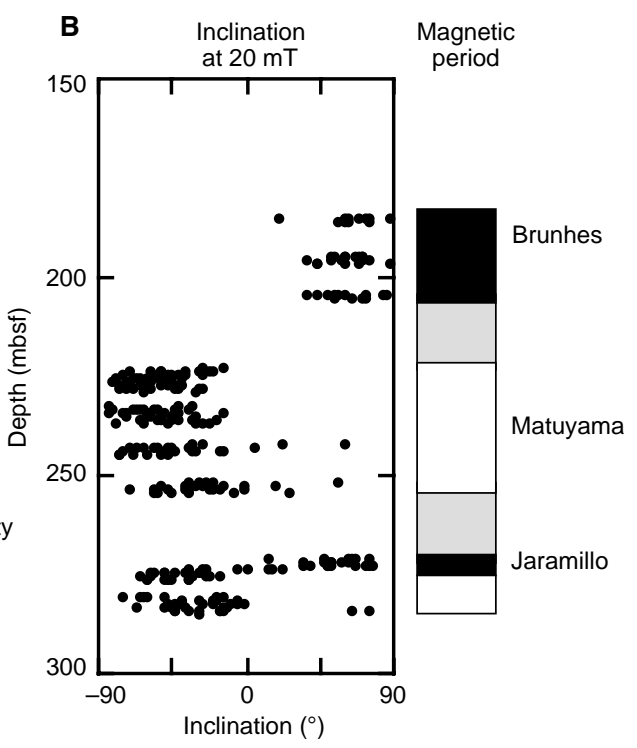

Figure 10. Inclination of remanent magnetization after 20-mT demagnetization for (A) Hole $1029 \mathrm{~A}$ and (B) Hole 1032A. The base of the Brunhes is placed at $175 \mathrm{mbsf}$ in Hole 1029A, and in an interval of no data between 205 and $220 \mathrm{mbsf}$ in Hole 1032A. The Jaramillo is present in Hole 1032A and possibly in Hole 1029A.

spectively. Although there often is a change in sediment properties that necessitates a change in coring method, the abrupt offsets in some physical properties may reflect greater core disturbance during $\mathrm{XCB}$ coring. To minimize this effect, discrete samples from the drilling biscuits were always carefully scraped clean of all obviously disturbed material. All sediment cores from Holes 1030B and 1031A were APC cored, whereas Hole 1032A was RCB cored.

\section{Multisensor Track Measurements}

Magnetic susceptibility data were used to separate fine-grained layers from coarser turbidite bases. Subsequent sample clusters were routinely taken in the fine-grained layers. The offset between index properties (IP) bulk density and gamma-ray attenuation porosity evaluator (GRAPE) determinations, described earlier (see "Physical Properties" section, "Hydrothermal Transition Transect" chapter, this volume), is present at this site as well.

Natural gamma-ray records show no systematic differences between sand and mud. The NGR profiles of sediment from the bases of Holes 1028A and 1031A show an abrupt decrease within $10 \mathrm{~m}$ of basement (Fig. 20). This pattern may reflect alteration of the sedi- ment near basement, but its absence in sediment from the base of Hole $1030 \mathrm{~B}$ is puzzling. Post-cruise studies may provide an explanation.

\section{Index Properties}

The porosity profiles measured for Holes 1030B and 1031A are relatively constant with depth and lack the compaction gradients observed in sediment near the surface of holes along the Hydrothermal Transition and Rough Basement Transects. Sediments from Holes $1030 \mathrm{~B}$ and 1031A also have relatively high carbonate content and very little sand. Whether the observed porosity profiles reflect differences in lithology or the active pore-water upwelling inferred for these sites (see "Geochemistry" section, this chapter) is uncertain at present.

Two turbidite layers from Hole 1028A were chosen for a finescale investigation of variations in index properties. Figure 21 shows the porosity, bulk density, and grain density of these turbidites. Although the turbidite bases are sharply defined, with upward decreases in porosity and increases in bulk density, index properties of the turbidites do not follow simple trends associated with grading. Grain 


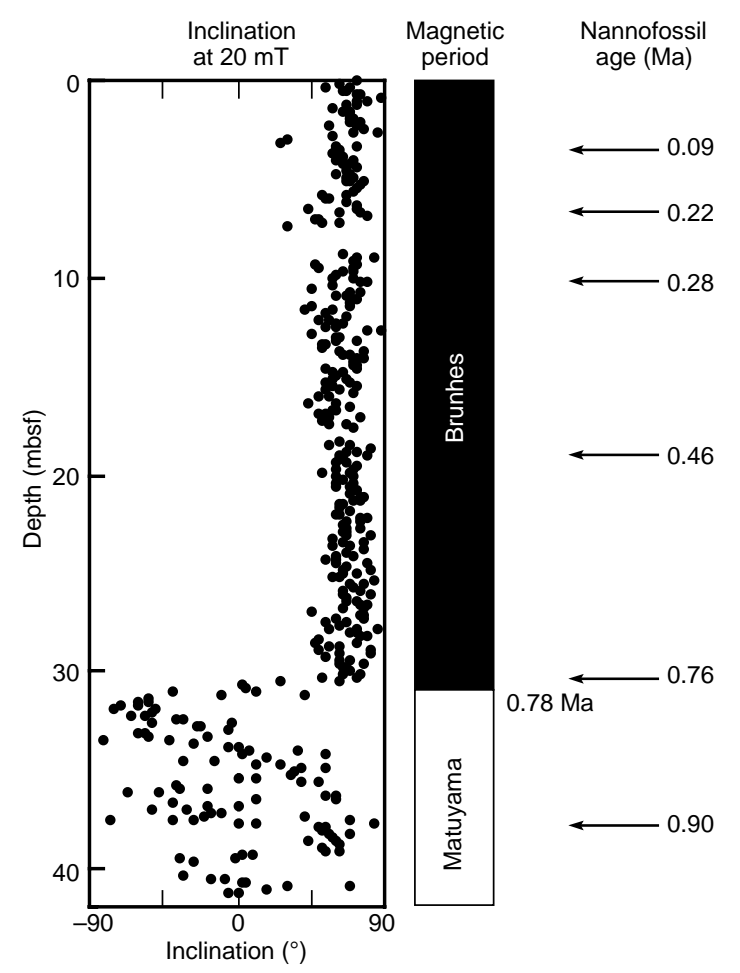

Figure 11. Inclination of remanent magnetization after 20-mT demagnetization for Hole 1031A. The Brunhes/Matuyama boundary is placed at 30 mbsf. The magnetostratigraphy of Hole 1030B is similar.

densities, although scattered, appear to initially increase upward and then decrease near the top of the two turbidites (Table 15 on CDROM, back pocket).

\section{DSV $P$-wave Velocity}

Figure 22 shows the relationship between porosity and DSV velocity in sediment from Holes 1028A, 1029A, and 1032A compared with two reference curves (see "Physical Properties" section, "Rough Basement Transect" chapter for additional discussion). There is good agreement between the data for Holes 1029A and 1032A and the curve derived from Cascadia Basin (Shipboard Scientific Party, 1994). Below about $55 \%$ porosity, velocity varies with porosity. However, for porosities between $45 \%$ and $55 \%$, velocities measured on sediment from Holes 1029A and 1032A are as much as $200 \mathrm{~m} / \mathrm{s}$ faster than those measured for corresponding porosities at the Rough Basement sites, indicating a higher matrix velocity.

\section{Thermal Conductivity}

Thermal conductivity values were obtained from full-space needle-probe measurements on all cores recovered from Holes 1028A and 1029B. During measurements on cores from Hole 1030B, the control unit failed, requiring repair and recalibration. No measurements were made of cores from the lower part of Hole 1030B (below Core 168-1030B-2H) or from Hole 1031A. The RCB cores from Hole 1032A were measured using the ThermCon 85 needle probes for Cores 168-1032A-1R and 2R, and with the TK04 halfspace line source in the split liner of all subsequent cores.

Figure 23 shows that the combined thermal conductivity data from Holes 1028A, 1029A, and 1032A produce a consistent profile to $300 \mathrm{mbsf}$. The correlation between porosity and thermal conductivity is shown in Figure 24.
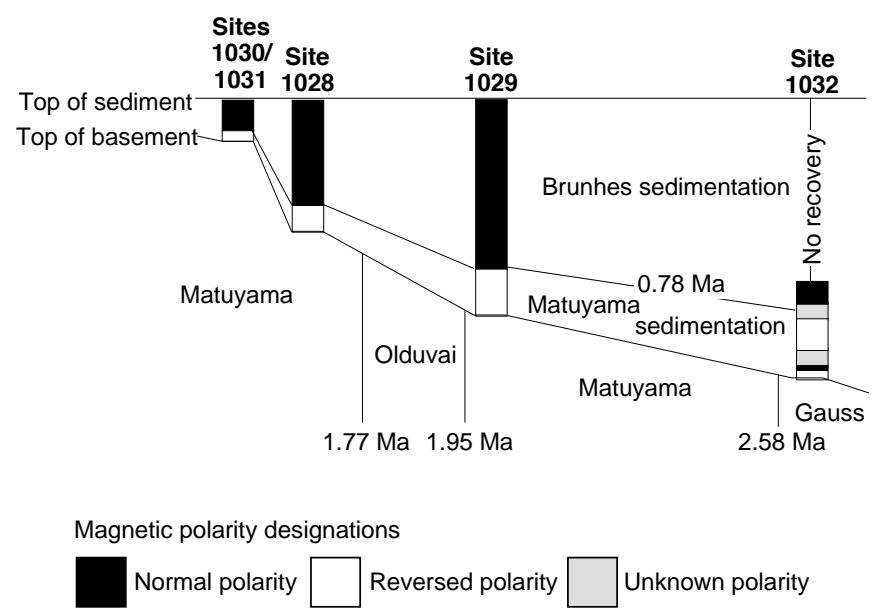

Figure 12. Schematic magnetostratigraphic cross-section of the Buried Basement Transect. Magnetic boundaries shown in basement are derived from seafloor magnetic anomalies (see "Introduction" chapter, this volume).

\section{Formation Factor}

Formation factor calculated from electrical resistance measurements in sediment increases from about 1.5 to 3.5 with depth at Site 1028 and from 2.5 to 6 at Site 1029. Sites 1030 and 1031, which exhibit upwelling of pore water, yielded a nearly constant value of 3 with depth. Only nine measurements were made at Site 1032, from 240 to 280 mbsf; values range from 7 to 14 . Sandy layers generally have higher values than does mud. Only Site 1029 provided sufficient data on sand to fit each of the two sediment types separately, using a power function (Table 16 on CD-ROM, back pocket). A weighted value for this function was then calculated for Site 1029 from the proportions of mud vs. sand given in Table 14 . The other sites had $<8 \%$ sand, so only the clay data were fit with either an exponential or power function. The resulting functions are $F F=1.1727 \mathrm{e}^{0.0088 d}$ for Hole $1028 \mathrm{~A}, \mathrm{FF}=1.2766 \mathrm{~d}^{0.2945}$ for Hole $1029 \mathrm{~A}, \mathrm{FF}=2.9601 \mathrm{~d}^{0.0147}$ for Hole $1030 \mathrm{~B}, \mathrm{FF}=3.192 \mathrm{e}^{0.004 \mathrm{~d}}$ for Hole 1031A, and $\mathrm{FF}=$ $0.8787 \mathrm{e}^{0.0089 \mathrm{~d}}$ for Hole $1032 \mathrm{~A}$, where $\mathrm{d}$ is depth in mbsf.

\section{THERMAL STUDIES}

\section{Sediment Measurements}

In situ temperatures were measured at six depths in Hole 1028A, nine depths in Hole 1029A, one depth in Hole 1030B, three depths in Hole 1031A, and six depths in Hole 1032A (Table 17). All tool deployments returned data that were used to estimate in situ temperatures, but APC tool runs 168-1031 A-3H and 4H and DVTP runs 1681031A-5H and 1032A-2R were disturbed and should be viewed with caution. Results of deployments in all holes are illustrated in Figures $25-28$.

The use of idealized thermal models to simulate tool response and the methods used for matching observations to the models to extrapolate equilibrium temperatures are discussed in the "Downhole Tools" section of the "Methods" chapter (this volume) and in Davis et al. (1997). As at other Leg 168 sites, the selection of sediment thermal conductivity values influenced the results of many of these extrapolations. Extrapolations based on a range of reasonable thermal conductivities (1.0 to $1.5 \mathrm{~W} /[\mathrm{m} \cdot \mathrm{K}])$ were calculated (Table 17$)$, and an intermediate value of $1.1 \mathrm{~W} /(\mathrm{m} \cdot \mathrm{K})$ was used for calculation of preliminary thermal gradients and heat flow (Figs. 29-32; Table 18). The symbols used to indicate equilibrium temperatures in these figures generally span the range of likely temperatures estimated using 
Figure 13. Composition of pore waters from the Buried Basement sites: sulfate, alkalinity, ammonia, and phosphate. Arrows $=$ the composition of bottom seawater.

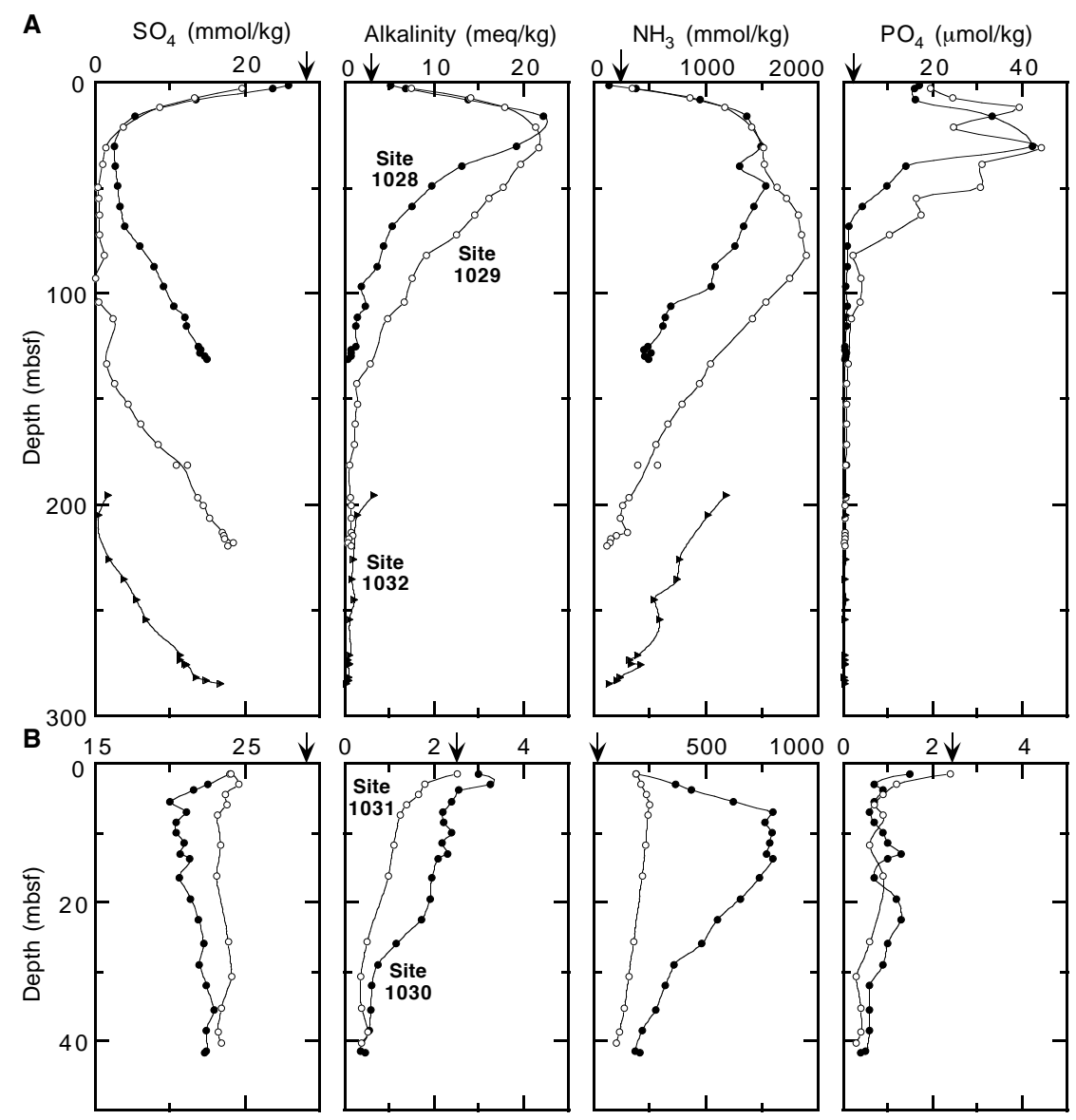

the range of thermal conductivity values listed above. A more sophisticated analysis of these extrapolations will be conducted post cruise.

The vertical thermal conductivity structure along the Buried Basement Transect was found to be remarkably consistent, although because of instrument problems few data were collected at Sites 1030 and 1031 ("Physical Properties" section, this chapter). The lithologyweighted harmonic mean thermal conductivity was calculated for each measurement depth using the combined data set.

Data from the APC tool and the DVTP provided consistent data in Hole 1028A (Fig. 29). The DVTP apparently produced more consistent data in Hole 1029A (Fig. 30). Only a single DVTP measurement was available in Hole 1030B, so the apparent thermal gradient and heat flow are not well constrained (Fig. 31). The record from APC tool deployment $168-1031 \mathrm{~A}-3 \mathrm{H}$ indicates significant tool disturbance (Fig. 27C), so this value was neglected in calculating the thermal gradient and heat flow in Hole 1031A (Fig. 32).

The highest heat flow values determined during Leg 168 were found at Sites 1030 and 1031 (Table 18). This appears to be a simple consequence of the basement temperature $\left(40^{\circ} \mathrm{C}\right)$, probably maintained by fluid flow, and the locally thin sediment layer. A significantly higher temperature at the top of basement was determined for Site $1028\left(50.5^{\circ} \mathrm{C}\right)$. Extrapolated temperatures at the top of basement at Sites 1029 and $1032\left(\sim 58^{\circ} \mathrm{C}\right)$ are surprisingly low relative to those anticipated on the basis of the theoretical lithospheric heat flow and the expected sealing influence of the sediments, but are well constrained by the measurements. There are no available nearby surface heat-flow data for the last three sites for comparison to these borehole results because probes failed to penetrate the seafloor during earlier surveys (Davis et al., this volume).

\section{DOWNHOLE MEASUREMENTS}

Hole 1032A was the only hole logged during Leg 168. Although the hole had been drilled well into basement with the hope of obtaining logging data across the sediment/basement contact, hole fill and bridging problems prevented passage of the tools below $283.9 \mathrm{mbsf}$ (6 $\mathrm{m}$ above basement). The following logging strings were run in Hole 1032A: triple combination string, the Formation MicroScanner (FMS) string and the geochemical string (Table 19). Descriptions of these strings are referenced in the "Downhole Tools" section of the "Methods" chapter (this volume).

The wireline heave compensator was used for all deployments and operated without problems in calm seas. The first tool string run in the hole was the triple combination string, which reached a total depth of 283.9 mbsf. A repeat section was logged with this string, and all data were of good quality except for data collected at the bottom of the hole, which was oversized. The logging speed was $900 \mathrm{ft} / \mathrm{hr}$, and both standard-mode (recorded at $15-\mathrm{cm}$ sampling) and highresolution-mode (2.5- and 5.08-cm sampling) data were recorded. The second logging run in Hole 1032A was with the FMS string, which reached $281.5 \mathrm{mbsf}$ and was repeated for a second pass. The logging speed was $1800 \mathrm{ft} / \mathrm{hr}$ both for the main and the repeat runs. The sonic data collected with this string were of low quality because the formation was soft and the hole was oversized at the bottom. The final logging run was with the geochemical tool string. This string reached $277.2 \mathrm{mbsf}$, and no repeat pass was attempted. Data quality was good with a logging speed of $600 \mathrm{ft} / \mathrm{hr}$.

Sonic data were pre-processed aboard ship to eliminate cycle skips. FMS data were also pre-processed aboard ship with fair results 
A
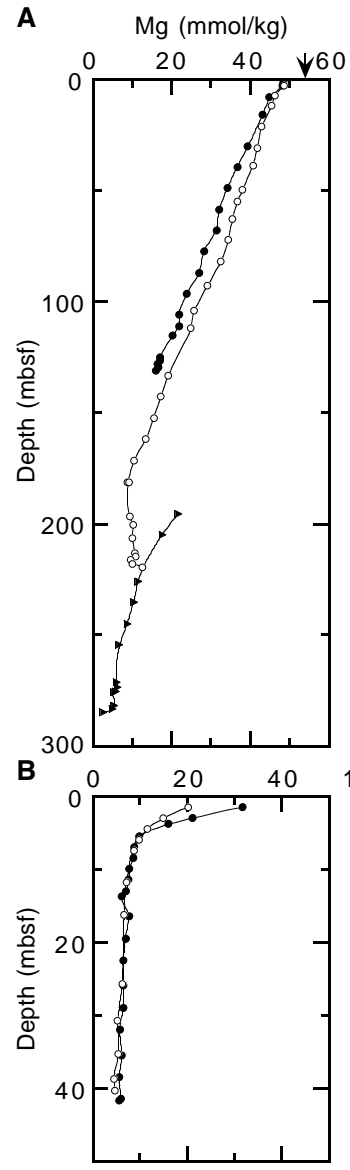

$\mathrm{Ca}(\mathrm{mmol} / \mathrm{kg})$
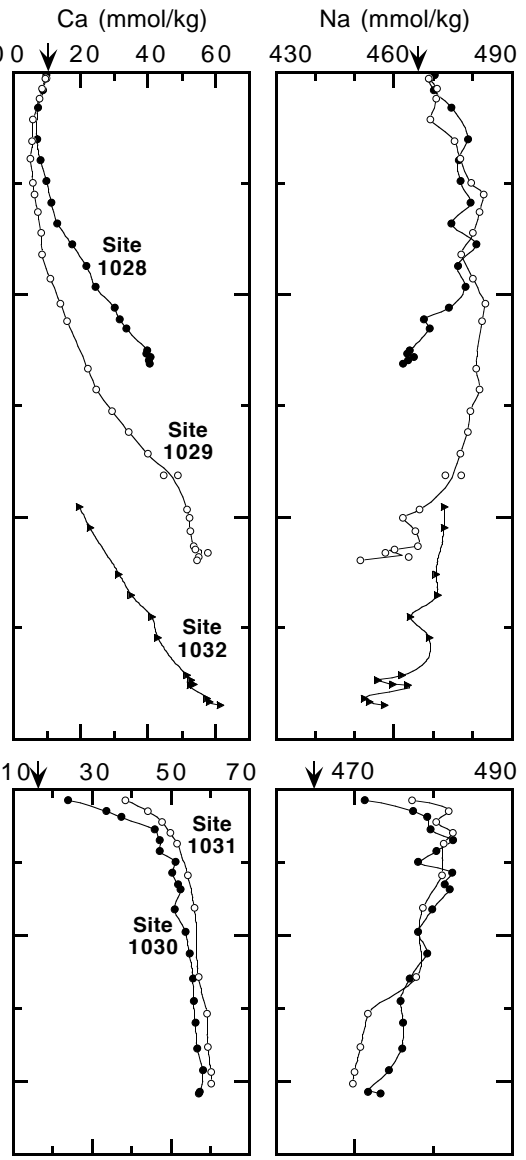

in the lower section of the hole and good results in the upper section of the hole. The FMS images and combined geophysical and geochemical data will complement core data (30\% recovery) to characterize the sedimentary section at Site 1032 . The turbidite sequence is particularly well represented by gamma-ray and FMS data.

The natural gamma-ray and bulk density data reflect the alternation of sandy and muddy layers observed in cores throughout Leg 168 (Fig. 33). FMS data are also useful for characterizing the alternation of mud and sand intervals, with highly resistive (bright) sand layers contrasting with relatively conductive (dark) mud layers (Fig. 34). Most beds are horizontal or dip shallowly $\left(<5^{\circ}\right)$ to the northeast.

Processed geochemical data from Hole 1032A show an unusually high aluminum concentration, even after performing additional processing post cruise (see logging figures at the end of this chapter). This result may reflect the use of sepiolite as a drilling mud or a weak Californium source in the neutron tool.

After processing and calculating oxide percentages, the normalization factor (see logging figures at the end of this chapter) shows that only the data from 245 to 275 mbsf are of low quality. The rest of the data are of reasonable quality, except for the high Al concentrations mentioned earlier. A major break in $\mathrm{K}_{2} \mathrm{O}$ concentration at 210 mbsf may reflect an increase in the occurrence of sand layers within the turbidite sequence. An increase in $\mathrm{FeO}$ and $\mathrm{SiO}_{2}$ concentrations is consistent with this trend. Peaks in $\mathrm{CaCO}_{3}-\mathrm{CaO}$ concentration are also common below 210 mbsf and correspond to low $\mathrm{SiO}_{2}$ concentration.

The Lamont-Doherty Earth Observatory (LDEO) temperature logging tool was run on the bottom of the triple combination string. The recorded temperatures (Fig. 35) reflect conditions in the borehole rather than the true formation temperature (as measured with the

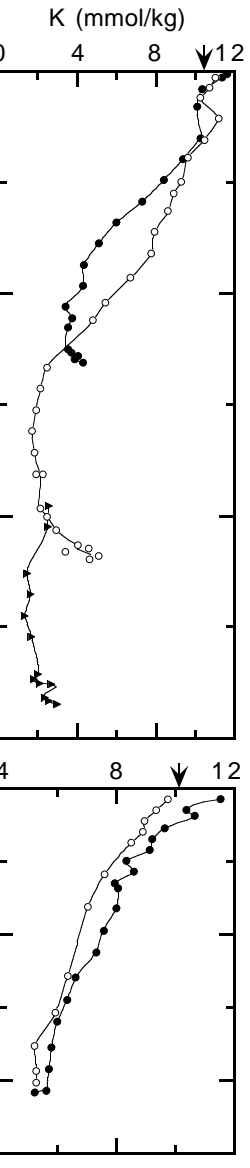

Figure 14. Composition of pore waters from Buried Basement sites: magnesium, calcium, sodium, and potassium. Arrows $=$ the composition of bottom seawater.

APC tool and the DVTP), although the borehole and in situ thermal gradients are similar.

A synthetic seismogram was constructed using density and sonic logs (Fig. 36). The synthetic seismic trace compares favorably with the shotpoint data from near Hole 1032A, particularly over the depth interval of 75-200 mbsf. Below 200 mbsf, two large seismic events on the synthetic seismogram are absent in the real seismic trace, perhaps indicating unfavorable hole conditions and lower quality density and velocity logs. Additional corrections of log data are needed in this deeper interval. The synthetic seismic reflection trace does not include a basement reflector because the wireline logs did not reach basement.

\section{REFERENCES}

Davis, E.E., Villinger, H., MacDonald, R.D., Meldrum, R.D., and Grigel, J., in press. A rapid-response probe for bottom-hole temperature measurements in deep-ocean boreholes. Mar. Geophys. Res.

Shipboard Scientific Party, 1987. Site 646. In Srivastava, S.P., Arthur, M., Clement, B., et al., Proc. ODP, Init. Repts., 105: College Station, TX (Ocean Drilling Program), 419-674.

, 1994. Site 888. In Westbrook, G.K., Carson, B., Musgrave, R.J., et al., Proc. ODP, Init. Repts., 146 (Pt. 1): College Station, TX (Ocean Drilling Program), 55-125.

Wheat, C.G., and Mottl, M.G., 1994. Hydrothermal circulation, Juan de Fuca Ridge eastern flank: factors controlling basement water composition. $J$. Geophys. Res., 99:3067-3080.

Ms 168IR-106 
NOTE: For all sites drilled, core-description forms ("barrel sheets") and core photographs can be found in Section 3, beginning on page 213. Smear-slide data and thinsection data can be found on CD-ROM. See Table of Contents for material contained on CD-ROM.

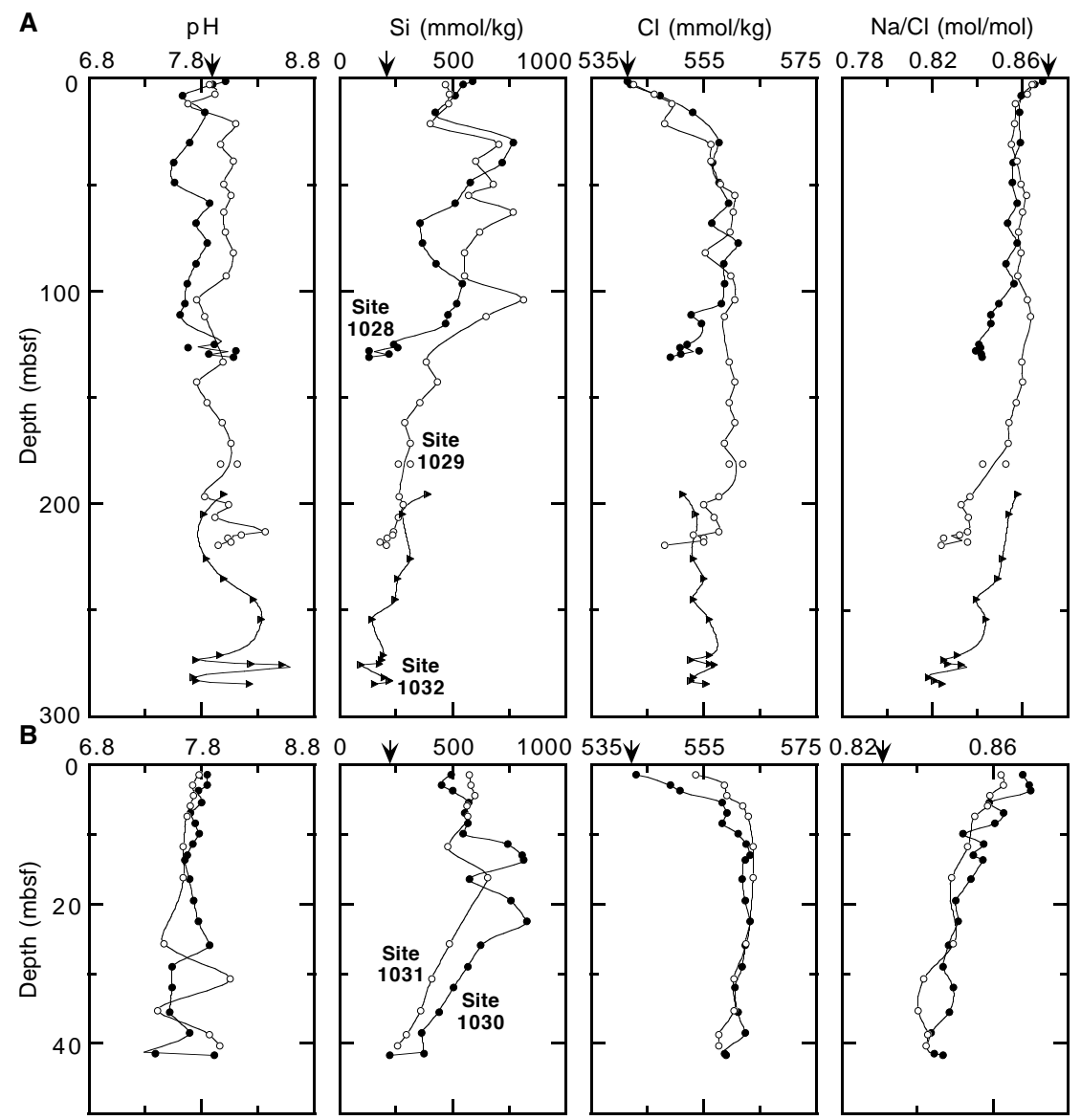

Figure 15. Composition of pore waters from Buried Basement sites: $\mathrm{pH}$, silica, chloride, and the sodium/chloride ratio. Arrows = the composition of bottom seawater. 
Table 10. Composition of pore waters from sediments from Sites 1028, 1029, 1030, 1031, and 1032.

\begin{tabular}{|c|c|c|c|c|c|c|c|c|c|c|c|c|c|c|c|c|}
\hline $\begin{array}{l}\text { Core, section, } \\
\text { interval }(\mathrm{cm})\end{array}$ & $\begin{array}{l}\text { Volume } \\
(\mathrm{mL})\end{array}$ & $\begin{array}{c}\text { In situ } \mathrm{T} \\
\left({ }^{\circ} \mathrm{C}\right)\end{array}$ & $\begin{array}{l}\text { Depth } \\
\text { (mbsf) }\end{array}$ & $\begin{array}{l}\text { Salinity } \\
\text { (R.I.,\%) }\end{array}$ & $\mathrm{pH}$ & $\begin{array}{l}\text { Alkalinity } \\
\text { (meq/kg) }\end{array}$ & $\begin{array}{l}\text { Chlorinity } \\
(\mathrm{mmol} / \mathrm{kg})\end{array}$ & $\begin{array}{c}\text { Sulfate } \\
(\mathrm{mmol} / \mathrm{kg})\end{array}$ & $\begin{array}{c}\mathrm{Na} \\
(\mathrm{mmol} / \mathrm{kg})\end{array}$ & $\begin{array}{c}\mathrm{K} \\
(\mathrm{mmol} / \mathrm{kg})\end{array}$ & $\begin{array}{c}\mathrm{Mg} \\
(\mathrm{mmol} / \mathrm{kg})\end{array}$ & $\begin{array}{c}\mathrm{Ca} \\
(\mathrm{mmol} / \mathrm{kg})\end{array}$ & $\begin{array}{c}\mathrm{Si} \\
(\mathrm{mmol} / \mathrm{kg})\end{array}$ & $\begin{array}{c}\mathrm{NH}_{3} \\
(\mathrm{mmol} / \mathrm{kg})\end{array}$ & $\begin{array}{c}\mathrm{PO}_{4} \\
(\mathrm{mmol} / \mathrm{kg})\end{array}$ & $\mathrm{Na} / \mathrm{Cl}$ \\
\hline \multicolumn{17}{|l|}{$168-1028 \mathrm{~A}-$} \\
\hline $1 \mathrm{H}-1,140-150$ & 50 & 2.3 & 1.45 & 35.0 & 8.01 & 5.13 & 541.5 & 25.85 & 470.4 & 11.61 & 48.37 & 9.80 & 587 & 138 & 17.1 & 0.8687 \\
\hline $1 \mathrm{H}-2,140-150$ & 40 & 2.9 & 2.95 & 35.0 & 7.90 & 6.85 & 542.0 & 23.72 & 469.0 & 11.37 & 48.16 & 9.78 & 546 & 375 & 15.9 & 0.8654 \\
\hline $2 \mathrm{H}-3,150-160$ & 50 & 4.8 & 8.25 & 34.5 & 7.63 & 13.77 & 547.3 & 13.51 & 470.2 & 10.37 & 44.88 & 8.88 & 509 & 952 & 16.1 & 0.8591 \\
\hline $3 \mathrm{H}-2,140-150$ & 50 & 7.7 & 16.15 & 34.0 & 7.83 & 22.24 & 553.0 & 5.33 & 474.7 & 10.10 & 43.11 & 7.43 & 424 & 1370 & 33.3 & 0.8584 \\
\hline $4 \mathrm{H}-5,140-150$ & 45 & 12.9 & 30.15 & 34.0 & 7.69 & 19.24 & 557.6 & 2.55 & 478.8 & 10.27 & 39.41 & 7.03 & 766 & 1492 & 42.2 & 0.8587 \\
\hline $5 \mathrm{H}-5,140-150$ & 50 & 16.4 & 39.65 & 33.5 & 7.55 & 13.12 & 556.6 & 2.71 & 476.4 & 9.37 & 36.66 & 8.05 & 717 & 1300 & 14.0 & 0.8558 \\
\hline $6 \mathrm{H}-5,140-150$ & 50 & 19.9 & 49.15 & 33.0 & 7.56 & 9.78 & 557.6 & 3.01 & 476.9 & 8.41 & 34.16 & 9.88 & 576 & 1532 & 9.8 & 0.8553 \\
\hline $7 \mathrm{H}-5,140-150$ & 50 & 23.4 & 58.65 & 32.5 & 7.87 & 7.51 & 559.3 & 3.39 & 479.5 & 7.30 & 32.09 & 11.28 & 511 & 1431 & 4.3 & 0.8574 \\
\hline $8 \mathrm{H}-5,140-150$ & 50 & 26.8 & 68.15 & 33.0 & 7.75 & 5.35 & 556.4 & 3.94 & 474.7 & 6.01 & 31.35 & 13.06 & 354 & 1336 & 1.3 & 0.8533 \\
\hline $9 \mathrm{H}-5,135-150$ & 50 & 30.3 & 77.63 & 33.0 & 7.85 & 4.40 & 561.0 & 5.96 & 481.0 & 5.09 & 28.23 & 17.38 & 366 & 1260 & 1.1 & 0.8574 \\
\hline $10 \mathrm{H}-5,135-150$ & 50 & 33.8 & 87.13 & 33.5 & 7.75 & 3.68 & 558.5 & 7.93 & 476.2 & 4.35 & 27.04 & 21.71 & 427 & 1082 & 1.0 & 0.8526 \\
\hline $11 \mathrm{H}-5,135-150$ & 50 & 37.3 & 96.63 & 33.5 & 7.67 & 1.91 & 558.6 & 9.22 & 478.1 & 4.32 & 23.87 & 24.36 & 541 & 1046 & 0.7 & 0.8560 \\
\hline $12 \mathrm{H}-5,135-150$ & 50 & 40.8 & 106.13 & 34.0 & 7.65 & 2.37 & 558.1 & 10.52 & 474.0 & 3.41 & 21.98 & 30.06 & 516 & 691 & 1.0 & 0.8493 \\
\hline $13 X-2,135-150$ & 50 & 42.6 & 111.13 & 33.5 & 7.61 & 1.50 & 552.7 & 12.05 & 467.5 & 3.76 & 22.05 & 31.48 & 479 & 635 & 0.8 & 0.8458 \\
\hline $13 \mathrm{X}-5,135-150$ & 36 & 44.2 & 115.50 & 33.5 & 1.01 & 1.31 & 554.6 & 12.27 & 469.1 & 3.55 & 20.29 & 33.62 & 467 & 616 & 0.8 & 0.8458 \\
\hline $15 \mathrm{X}-1,135-150$ & 25 & 47.8 & 125.23 & 34.0 & 7.91 & 1.31 & 552.1 & 13.86 & 464.1 & 3.52 & 17.06 & 39.70 & 238 & 486 & 0.5 & 0.8406 \\
\hline $15 \mathrm{X}-2,135-150$ & 35 & 48.4 & 126.73 & 34.0 & 7.68 & 0.73 & 550.7 & 14.17 & 463.3 & 3.70 & 17.01 & 39.36 & 258 & 447 & 0.5 & 0.8413 \\
\hline $15 \mathrm{X}-3,135-150$ & 18 & 48.9 & 128.23 & 34.0 & 8.10 & 0.78 & 554.2 & 14.06 & 465.1 & 4.05 & 16.47 & 40.51 & 129 & 517 & 0.8 & 0.8392 \\
\hline $15 \mathrm{X}-4,135-150$ & 40 & 49.5 & 129.73 & 34.0 & 7.86 & 0.77 & 550.9 & 14.69 & 463.6 & 3.86 & 16.58 & 40.17 & 216 & 460 & 0.7 & 0.8417 \\
\hline $15 X-6,0-15$ & 40 & 50.1 & 131.38 & 34.0 & 8.08 & 0.38 & 549.0 & 15.01 & 462.3 & 4.32 & 16.02 & 40.36 & 131 & 490 & 0.4 & 0.8421 \\
\hline Basement at: & & 50.5 & 132.5 & & & & & & & & & & & & & \\
\hline \multicolumn{17}{|c|}{ Basement age $=1.62 \mathrm{Ma}$} \\
\hline \multicolumn{17}{|l|}{$168-1029 \mathrm{~A}-$} \\
\hline $1 \mathrm{H}-2,140-150$ & 55 & 2.6 & 2.95 & 34.5 & 7.87 & 7.46 & 542.6 & 19.70 & 468.8 & 11.05 & 48.57 & 9.69 & 469 & 341 & 19.6 & 0.8640 \\
\hline $2 \mathrm{H}-2,140-150$ & 55 & 3.7 & 7.45 & 34.5 & 7.92 & 14.04 & 546.2 & 13.31 & 470.9 & 10.74 & 46.30 & 8.66 & 485 & 861 & 24.4 & 0.8621 \\
\hline $2 \mathrm{H}-5,140-150$ & 55 & 4.9 & 11.95 & 34.0 & 7.68 & 17.90 & 549.4 & 8.67 & 470.8 & 10.29 & 45.49 & 7.82 & 481 & 1169 & 39.3 & 0.8569 \\
\hline $3 \mathrm{H}-5,140-150$ & 7 & 7.3 & 21.45 & 33.5 & 8.10 & 21.27 & 548.1 & 3.76 & 469.4 & 11.18 & 42.93 & 5.87 & 400 & 1408 & 24.6 & 0.8565 \\
\hline $4 \mathrm{H}-5,140-150$ & 55 & 9.8 & 30.95 & 33.5 & 7.97 & 21.63 & 556.2 & 1.42 & 475.5 & 10.46 & 41.87 & 5.74 & 703 & 1515 & 44.3 & 0.8549 \\
\hline $5 \mathrm{H}-4,140-150$ & 55 & 11.9 & 38.95 & 33.5 & 8.08 & 19.60 & 556.2 & 0.98 & 476.9 & 9.63 & 40.70 & 5.10 & 603 & 1518 & 30.9 & 0.8574 \\
\hline $6 \mathrm{H}-5,140-150$ & 55 & 14.7 & 49.95 & 33.0 & 8.00 & 17.66 & 558.0 & 0.44 & 479.6 & 9.29 & 38.03 & 5.89 & 680 & 1630 & 30.6 & 0.8594 \\
\hline $7 \mathrm{H}-2,140-150$ & 55 & 16.0 & 54.95 & 33.0 & 8.06 & 16.08 & 560.5 & 0.53 & 482.9 & 8.92 & 36.82 & 6.20 & 570 & 1717 & 16.3 & 0.8615 \\
\hline $8 \mathrm{H}-1,140-150$ & 55 & 18.1 & 62.95 & 33.0 & 8.00 & 14.52 & 560.2 & 0.62 & 481.8 & 8.64 & 35.56 & 7.32 & 767 & 1822 & 17.3 & 0.8601 \\
\hline $9 \mathrm{H}-1,140-150$ & 55 & 20.5 & 72.45 & 33.0 & 8.01 & 12.47 & 559.6 & 0.57 & 480.2 & 7.95 & 34.46 & 8.19 & 618 & 1855 & 10.3 & 0.8580 \\
\hline $10 \mathrm{H}-1,140-150$ & 22 & 23.0 & 81.95 & 33.0 & 8.08 & 9.13 & 555.2 & 1.25 & 477.0 & 7.79 & 32.63 & 8.59 & 553 & 1893 & 2.3 & 0.8592 \\
\hline $11 \mathrm{H}-2,140-150$ & 50 & 25.8 & 92.95 & 33.0 & $\begin{array}{l}8.000 \\
8.02\end{array}$ & 7.54 & 559.8 & 0.00 & 480.1 & 6.73 & 29.20 & 10.97 & 551 & 1747 & 4.0 & 0.8577 \\
\hline $12 \mathrm{H}-3,140-150$ & 55 & 28.7 & 103.95 & 33.0 & $\begin{array}{l}0.02 \\
7.76\end{array}$ & 6.69 & 560.5 & 0.46 & 483.2 & 5.46 & 25.77 & 14.02 & 812 & 1538 & 3.8 & 0.8621 \\
\hline $13 \mathrm{X}-2,135-150$ & 55 & 30.7 & 111.93 & & 7.83 & 4.81 & 558.6 & 2.46 & 482.4 & 4.83 & 24.97 & 16.02 & 647 & 1413 & 1.8 & 0.8636 \\
\hline $16 \mathrm{X}-2,135-150$ & 50 & 36.3 & 133.33 & 33.0 & 7.99 & 2.89 & 559.5 & 1.53 & 480.9 & 2.46 & 19.21 & 22.08 & 384 & 1042 & 1.2 & 0.8596 \\
\hline $17 \mathrm{X}-2,130-150$ & 50 & 38.7 & 142.90 & 33.0 & 7.76 & 1.36 & 560.5 & 2.54 & 481.9 & 2.14 & 17.24 & 24.65 & 433 & 946 & 0.9 & 0.8598 \\
\hline $18 \mathrm{X}-2,130-150$ & 50 & 41.2 & 152.50 & 33.0 & 7.85 & 1.41 & 559.5 & 4.37 & 479.5 & 1.92 & 15.52 & 29.38 & 353 & 785 & 0.8 & 0.8570 \\
\hline $19 \mathrm{X}-2,130-150$ & 45 & 43.7 & 162.10 & 34.0 & 7.98 & 1.17 & 560.5 & 6.06 & 478.7 & 1.72 & 13.46 & 34.29 & 288 & 664 & 0.8 & 0.8540 \\
\hline $20 \mathrm{X}-2,130-150$ & 42 & 46.2 & 171.70 & 33.5 & 8.06 & 1.09 & 558.6 & 8.41 & 476.9 & 1.83 & 10.51 & 39.87 & 313 & 557 & 0.8 & 0.8537 \\
\hline $21 X-2,130-150$ & 50 & 48.7 & 181.30 & 34.5 & 7.97 & 0.60 & 559.5 & 10.90 & 477.0 & 1.93 & 8.80 & 44.59 & 313 & 569 & 0.8 & 0.8526 \\
\hline $22 \mathrm{X}-2,130-150$ & 32 & 51.3 & 190.90 & 34.5 & 8.12 & 0.60 & 561.9 & 12.30 & 473.2 & 2.28 & 9.24 & 48.73 & 261 & 395 & 0.6 & 0.8422 \\
\hline $22 X-6,130-150$ & 20 & 52.7 & 196.90 & 35.0 & 7.83 & 0.65 & 557.7 & 13.71 & 466.5 & 2.12 & 9.45 & 51.52 & 263 & 316 & 0.6 & 0.8366 \\
\hline $23 \mathrm{X}-2,130-150$ & 42 & 53.6 & 200.50 & 35.0 & 8.04 & 0.72 & 555.0 & 14.44 & 462.3 & 2.49 & 10.28 & 52.19 & 282 & 255 & 0.4 & 0.8329 \\
\hline $23 \mathrm{X}-6,130-150$ & 40 & 55.2 & 206.50 & 35.0 & 7.92 & 0.71 & 556.9 & 15.36 & 465.5 & 2.96 & 10.13 & 52.48 & 261 & 240 & 0.4 & 0.8359 \\
\hline $24 \mathrm{X}-4,125-150$ & 42 & 56.9 & 213.10 & 35.5 & 8.36 & 0.74 & 557.7 & 17.04 & 466.1 & 4.04 & 10.66 & 53.54 & 238 & 297 & 0.4 & 0.8357 \\
\hline $24 \mathrm{X}-5,125-150$ & 34 & 57.3 & 214.60 & 35.5 & 8.15 & 0.95 & 553.1 & 17.26 & 460.2 & 4.58 & 10.82 & 54.12 & 236 & 200 & 0.4 & 0.8320 \\
\hline $24 \mathrm{X}-6,125-150$ & 32 & 57.7 & 216.10 & 35.5 & 8.03 & 0.53 & 555.0 & 17.31 & 457.8 & 3.42 & 9.76 & 57.74 & 212 & 153 & 0.4 & 0.8249 \\
\hline $25 \mathrm{X}-1,125-150$ & 35 & 58.2 & 218.20 & 35.5 & 8.06 & 0.42 & 555.0 & 18.48 & 463.7 & 5.11 & 10.12 & 54.90 & 179 & 143 & 0.3 & 0.8356 \\
\hline $25 \mathrm{X}-2,125-150$ & 40 & 58.6 & 219.70 & 35.0 & 7.95 & 0.79 & 548.0 & 17.69 & 451.5 & 4.66 & 12.67 & 54.46 & 208 & 115 & 0.4 & 0.8239 \\
\hline Basement at: & & 58.7 & 220.1 & & & & & & & & & & & & & \\
\hline \multicolumn{17}{|c|}{ Basement age $=1.95 \mathrm{Ma}$} \\
\hline \multicolumn{17}{|c|}{$168-1030 \mathrm{~B}-$} \\
\hline $1 \mathrm{H}-1,140-150$ & 30 & 3.0 & 1.45 & 35.0 & 7.85 & 3.00 & 543.0 & 24.02 & 471.3 & 11.52 & 31.70 & 23.92 & 493 & 191 & 1.5 & 0.8679 \\
\hline $1 \mathrm{H}-2,140-150$ & 30 & 4.2 & 2.95 & 35.0 & 7.85 & 3.26 & 549.0 & 22.54 & 477.4 & 10.36 & 21.07 & 33.72 & 449 & 367 & 0.7 & 0.8696 \\
\hline $74-84$ & 30 & 4.9 & 3.79 & 34.5 & 7.77 & 2.55 & 550.8 & 21.59 & 479.2 & 10.66 & 15.92 & 37.42 & 499 & 436 & 0.9 & 0.8700 \\
\hline $2 \mathrm{H}-1,140-150$ & 30 & 6.3 & 5.45 & 35 & 7.80 & 2.40 & 558.2 & 20.02 & 479.6 & 9.64 & 9.79 & 45.92 & 571 & 623 & 0.7 & 0.8591 \\
\hline $2 \mathrm{H}-2,140-150$ & 30 & 7.5 & 6.95 & 35.0 & 7.70 & 2.20 & 559.1 & 21.12 & 482.5 & 9.22 & 8.64 & 47.27 & 552 & 798 & 0.6 & 0.8630 \\
\hline $2 \mathrm{H}-3,140-150$ & 30 & 8.7 & 8.45 & 35.5 & 7.74 & 2.22 & 558.2 & 20.44 & 480.4 & 9.12 & 8.63 & 47.27 & 565 & 764 & 0.7 & 0.8605 \\
\hline $2 \mathrm{H}-4,140-150$ & 30 & 9.9 & 9.95 & 35.5 & 7.78 & 2.40 & 561.0 & 20.45 & 478.1 & 8.33 & 7.73 & 51.21 & 546 & 795 & 0.9 & 0.8522 \\
\hline $2 \mathrm{H}-5,140-150$ & 30 & 11.2 & 11.45 & 35.5 & 7.72 & 2.18 & 562.5 & 20.96 & 482.4 & 8.58 & 7.49 & 50.35 & 744 & 784 & 1.0 & 0.8575 \\
\hline
\end{tabular}


Table 10 (continued).

\begin{tabular}{|c|c|c|c|c|c|c|c|c|c|c|c|c|c|c|c|c|}
\hline $\begin{array}{l}\text { Core, section, } \\
\text { interval }(\mathrm{cm})\end{array}$ & $\begin{array}{c}\text { Volume } \\
(\mathrm{mL})\end{array}$ & $\begin{array}{c}\text { In situ } \mathrm{T} \\
\left({ }^{\circ} \mathrm{C}\right)\end{array}$ & $\begin{array}{l}\text { Depth } \\
\text { (mbsf) }\end{array}$ & $\begin{array}{l}\text { Salinity } \\
\text { (R.I.,\%) }\end{array}$ & $\mathrm{pH}$ & $\begin{array}{r}\text { Alkalinity } \\
(\mathrm{meq} / \mathrm{kg})\end{array}$ & $\begin{array}{l}\text { Chlorinity } \\
(\mathrm{mmol} / \mathrm{kg})\end{array}$ & $\begin{array}{c}\text { Sulfate } \\
(\mathrm{mmol} / \mathrm{kg})\end{array}$ & $\begin{array}{c}\mathrm{Na} \\
(\mathrm{mmol} / \mathrm{kg})\end{array}$ & $\underset{(\mathrm{mmol} / \mathrm{kg})}{\mathrm{K}}$ & $\begin{array}{c}\mathrm{Mg} \\
(\mathrm{mmol} / \mathrm{kg})\end{array}$ & $\begin{array}{c}\mathrm{Ca} \\
(\mathrm{mmol} / \mathrm{kg})\end{array}$ & $\begin{array}{c}\mathrm{Si} \\
(\mathrm{mmol} / \mathrm{kg})\end{array}$ & $\begin{array}{c}\mathrm{NH}_{3} \\
(\mathrm{mmol} / \mathrm{kg})\end{array}$ & $\begin{array}{c}\mathrm{PO}_{4} \\
(\mathrm{mmol} / \mathrm{kg})\end{array}$ & $\mathrm{Na} / \mathrm{Cl}$ \\
\hline $2 \mathrm{H}-6,140-150$ & 30 & 12.4 & 12.95 & 35.5 & 7.67 & 2.30 & 563.2 & 20.71 & 481.4 & 7.95 & 6.99 & 51.78 & 806 & 772 & 1.3 & 0.8548 \\
\hline $2 \mathrm{H}-7,62-72$ & 30 & 13.0 & 13.67 & 36.0 & 7.65 & 2.09 & 562.3 & 21.35 & 482.1 & 8.04 & 6.13 & 52.36 & 814 & 800 & 1.0 & 0.8573 \\
\hline $3 \mathrm{H}-2,140-150$ & 30 & 15.2 & 16.45 & 35.5 & 7.69 & 1.96 & 561.8 & 20.63 & 479.9 & 7.99 & 7.65 & 50.92 & 573 & 739 & 0.7 & 0.8542 \\
\hline $3 \mathrm{H}-4,140-150$ & 30 & 17.7 & 19.45 & 36.0 & 7.73 & 1.91 & 562.3 & 21.41 & 478.1 & 7.56 & 6.99 & 53.70 & 755 & 654 & 1.2 & 0.8502 \\
\hline $3 \mathrm{H}-6,140-150$ & 30 & 20.1 & 22.45 & 36.0 & 7.77 & 1.72 & 563.2 & 21.92 & 479.2 & 7.31 & 6.38 & 54.76 & 827 & 553 & 1.3 & 0.8508 \\
\hline $4 \mathrm{H}-2,140-150$ & 30 & 23.0 & 25.95 & 36.0 & 7.87 & 1.16 & 562.3 & 22.27 & 477.0 & 6.61 & 6.54 & 55.68 & 624 & 482 & 1.0 & 0.8482 \\
\hline $4 \mathrm{H}-4,140-150$ & 30 & 25.5 & 28.95 & 36.0 & 7.54 & 0.75 & 561.8 & 21.98 & 475.8 & 6.33 & 6.38 & 55.82 & 565 & 360 & 0.9 & 0.8469 \\
\hline $4 \mathrm{H}-6,140-150$ & 30 & 27.9 & 31.95 & 36.0 & 7.54 & 0.61 & 560.5 & 22.45 & 476.2 & 6.00 & 5.72 & 56.20 & 504 & 320 & 0.6 & 0.8495 \\
\hline $5 \mathrm{H}-2,140-150$ & 30 & 30.8 & 35.45 & 36.0 & 7.52 & 0.59 & 561.0 & 22.96 & 476.0 & 5.81 & 6.17 & 56.68 & 438 & 278 & 0.6 & 0.8485 \\
\hline $5 \mathrm{H}-4,140-150$ & 30 & 33.2 & 38.45 & 36.0 & 7.69 & 0.56 & 562.3 & 22.45 & 474.4 & 5.72 & 5.68 & 58.13 & 362 & 216 & 0.6 & 0.8437 \\
\hline $5 \mathrm{H}-6,140-150$ & 30 & 35.7 & 41.45 & 36.0 & 7.39 & 0.36 & 558.6 & 22.44 & 471.7 & 5.63 & 5.88 & 57.36 & 373 & 185 & 0.5 & 0.8445 \\
\hline $6 \mathrm{X}-\mathrm{CC}, 0-20$ & 30 & 35.8 & 41.65 & 35.5 & 7.91 & 0.46 & 559.0 & 22.33 & 473.3 & 5.24 & 5.68 & 57.12 & 221 & 206 & 0.4 & 0.8467 \\
\hline Basement at: & & 40.1 & 46.9 & & & & & & & & & & & 200 & & \\
\hline \multicolumn{17}{|c|}{ Basement age $=1.43 \mathrm{Ma}$} \\
\hline \multicolumn{17}{|l|}{ 168-1031A- } \\
\hline $1 \mathrm{H}-1,140-150$ & 50 & 3.2 & 1.45 & 35.5 & 7.78 & 2.52 & 553.6 & 24.07 & 477.3 & 9.76 & 20.20 & 38.41 & 575 & 190 & 2.4 & 0.8622 \\
\hline $1 \mathrm{H}-2,140-150$ & 50 & 4.6 & 2.95 & 35.5 & 7.72 & 1.79 & 558.7 & 24.58 & 482.0 & 9.35 & 15.01 & 44.13 & 580 & 212 & 1.2 & 0.8628 \\
\hline $1 \mathrm{H}-3,140-150$ & 50 & 6.0 & 4.45 & 35.5 & 7.73 & 1.66 & 559.1 & 23.69 & 480.4 & 8.97 & 11.54 & 47.83 & 597 & 233 & 0.9 & 0.8593 \\
\hline $1 \mathrm{H}-4,140-150$ & 50 & 7.4 & 5.95 & 36.0 & 7.70 & 1.38 & 561.9 & 23.81 & 482.5 & 8.91 & 9.88 & 49.87 & 563 & 250 & 0.7 & 0.8587 \\
\hline $2 \mathrm{H}-5,140-150$ & 50 & 8.8 & 7.45 & 36.0 & 7.67 & 1.24 & 562.8 & 23.20 & 481.3 & 8.50 & 8.64 & 51.69 & 567 & 241 & 0.9 & 0.8552 \\
\hline $2 \mathrm{H}-2,140-150$ & 50 & 12.8 & 11.75 & 36.0 & 7.64 & 1.10 & 563.7 & 23.37 & 481.1 & $\begin{array}{l}7.00 \\
7.60\end{array}$ & $\begin{array}{l}.0 .04 \\
7.16\end{array}$ & 54.28 & 480 & 232 & 0.6 & 0.8534 \\
\hline $3 \mathrm{H}-5,130-150$ & 50 & 16.9 & 16.20 & $\begin{array}{l}36.0 \\
36.0\end{array}$ & $\begin{array}{l}7.04 \\
7.64\end{array}$ & 0.98 & 563.7 & 23.15 & 478.7 & 7.03 & 6.62 & 56.01 & $\begin{array}{l}400 \\
656\end{array}$ & 216 & 0.9 & 0.8492 \\
\hline $4 \mathrm{H}-5,140-150$ & 50 & 25.9 & 25.75 & 36.0 & 7.47 & 0.51 & 562.5 & 23.90 & 477.9 & 6.35 & 6.21 & 57.07 & 487 & 178 & 0.6 & 0.8496 \\
\hline $4 \mathrm{H}-2,140-150$ & 50 & 30.6 & 30.75 & 36.0 & 8.05 & 0.37 & 560.3 & 24.12 & 471.7 & 5.94 & $\begin{array}{l}0.21 \\
5.33\end{array}$ & 59.18 & 406 & 156 & 0.3 & 0.8418 \\
\hline $5 \mathrm{H}-5,140-150$ & 50 & 34.8 & 35.25 & 36.0 & 7.41 & 0.39 & 560.3 & 23.45 & 470.8 & 5.23 & 5.44 & 59.47 & 358 & 138 & 0.4 & 0.8403 \\
\hline $5 \mathrm{H}-1,140-150$ & 50 & 38.0 & 38.75 & 36.0 & 7.87 & 0.53 & 557.7 & 23.23 & 470.0 & 5.29 & 4.44 & 60.24 & 295 & 114 & 0.4 & 0.8428 \\
\hline $5 \mathrm{H}-2,140-150$ & 50 & 39.4 & 40.25 & 36.0 & 7.96 & 0.39 & 557.7 & 23.42 & 469.8 & 5.29 & 4.65 & 60.27 & 257 & 100 & 0.3 & 0.8424 \\
\hline Basement at: & & 40.4 & 41.3 & & & & & & & & & & & & & \\
\hline \multicolumn{17}{|c|}{ Basement age $=1.43 \mathrm{Ma}$} \\
\hline \multicolumn{17}{|l|}{ 168-1032A- } \\
\hline $2 \mathrm{R}-1,130-150$ & 20 & 39.0 & 195.50 & 32.0 & 8.00 & 3.28 & 551.3 & 1.71 & 472.8 & 2.57 & 21.65 & 19.65 & 392 & 1182 & 0.8 & 0.8577 \\
\hline $3 \mathrm{R}-1,130-150$ & 36 & 40.9 & 205.10 & 32.0 & 7.82 & 1.48 & 553.6 & 0.53 & 472.8 & 2.50 & 17.63 & 22.77 & 277 & 1024 & 0.6 & 0.8541 \\
\hline $5 \mathrm{R}-2,130-150$ & 30 & 44.8 & 225.80 & 32.0 & 7.84 & 0.99 & 553.1 & 1.91 & 470.7 & 1.47 & 11.54 & 31.35 & 314 & 769 & 0.6 & 0.8510 \\
\hline $6 \mathrm{R}-2,130-150$ & 48 & 46.6 & 235.40 & 32.5 & 8.00 & 0.86 & 555.0 & 3.88 & 471.2 & $\begin{array}{l}1.64 \\
1.64\end{array}$ & 10.39 & 34.99 & 258 & 748 & 0.4 & 0.8490 \\
\hline $7 \mathrm{R}-2,130-150$ & 40 & 48.5 & 245.00 & 33.5 & $\begin{array}{l}0.00 \\
8.26\end{array}$ & $\begin{array}{l}0.00 \\
1.11\end{array}$ & 553.1 & 5.53 & 464.3 & $\begin{array}{l}1.04 \\
1.35\end{array}$ & 8.71 & 41.12 & 246 & 544 & 0.6 & 0.8394 \\
\hline $8 \mathrm{R}-2,130-150$ & 38 & 50.3 & 254.60 & 33.5 & 8.33 & 0.61 & 555.9 & 6.83 & 469.0 & 1.69 & 6.82 & 42.95 & 143 & 590 & 0.4 & 0.8436 \\
\hline $10 \mathrm{R}-1,43-63$ & 35 & 53.5 & 271.53 & 34.5 & 7.96 & 0.63 & 555.9 & 11.36 & 462.0 & 2.01 & 6.17 & 51.47 & 194 & 393 & 0.4 & 0.8311 \\
\hline $10 \mathrm{R}-2,88-108$ & 33 & 53.9 & 273.48 & 34.5 & 7.75 & 0.40 & 552.7 & 11.35 & 455.9 & 1.78 & 6.34 & 52.72 & 186 & 322 & 0.4 & 0.8249 \\
\hline $10 \mathrm{R}-3,130-150$ & 33 & 54.3 & 275.40 & 34.5 & 8.24 & 0.64 & 555.9 & 12.05 & 459.7 & 2.11 & 5.86 & 53.58 & 176 & 334 & 0.4 & 0.8269 \\
\hline $10 \mathrm{R}-4,30-50$ & 40 & 54.4 & 275.90 & 34.5 & 8.51 & 0.46 & 556.8 & 12.25 & 463.6 & 2.71 & 5.31 & 52.44 & 934 & 23 & 0.4 & 0.8326 \\
\hline $11 \mathrm{R}-1,130-150$ & 40 & 55.5 & 282.00 & 34.5 & 7.73 & 0.52 & 553.1 & 13.54 & 452.6 & 2.37 & 5.37 & 57.51 & 198 & 237 & 0.2 & 0.8182 \\
\hline $11 \mathrm{R}-2,130-150$ & 50 & 55.8 & 283.50 & 35.0 & 7.75 & 0.54 & 552.7 & 14.85 & 453.8 & 2.58 & 5.06 & 58.23 & 223 & 211 & 0.4 & 0.8210 \\
\hline $11 \mathrm{R}-3,130-150$ & 50 & 56.1 & 285.00 & 35.0 & 8.22 & 0.27 & 555.4 & 16.76 & 457.7 & 2.98 & 2.79 & 61.44 & 155 & 142 & 0.4 & 0.8242 \\
\hline Basement at: & & 57.1 & 290.3 & & & & & & & & & & & & & \\
\hline \multicolumn{17}{|l|}{ Basement age $=2.62$} \\
\hline
\end{tabular}

Notes: $\mathrm{T}=$ temperature, R.I. $=$ refractive index, and $-=$ not determined. $\mathrm{Mg}$ concentrations reported for Sections 168-1030B-1H-3 and below and 1031A-1H-5 and below were determined by flame atomic absorption spectrophotometry rather than titrimetry.

This table also appears on the volume CD-ROM. 
Table 11. Headspace composition data from Sites 1028, 1029, 1030, 1031, and 1032.

\begin{tabular}{|c|c|c|}
\hline $\begin{array}{l}\text { Core, section, } \\
\text { interval }(\mathrm{cm})\end{array}$ & $\begin{array}{l}\text { Depth } \\
\text { (mbsf) }\end{array}$ & $\begin{array}{c}\mathrm{C}_{1} \\
\text { (ppmv) }\end{array}$ \\
\hline $\begin{array}{c}168-1028 \mathrm{~A}- \\
1 \mathrm{H}-1,0-5 \\
2 \mathrm{H}-4,0-5 \\
3 \mathrm{H}-3,0-5 \\
4 \mathrm{H}-6,0-5 \\
5 \mathrm{H}-6,0-5 \\
6 \mathrm{H}-6,0-5 \\
7 \mathrm{H}-6,0-5 \\
8 \mathrm{H}-6,0-5 \\
9 \mathrm{H}-6,0-5 \\
10 \mathrm{H}-6,0-5 \\
11 \mathrm{H}-6,0-5 \\
12 \mathrm{H}-6,0-5 \\
13 \mathrm{H}-5,0-5 \\
15 \mathrm{H}-5,0-5\end{array}$ & $\begin{array}{r}0.03 \\
8.23 \\
16.23 \\
30.23 \\
39.73 \\
49.23 \\
58.73 \\
68.23 \\
77.73 \\
87.23 \\
96.73 \\
106.23 \\
114.23 \\
129.83\end{array}$ & $\begin{array}{l}2 \\
2 \\
3 \\
4 \\
5 \\
4 \\
4 \\
4 \\
6 \\
7 \\
8 \\
7 \\
6 \\
5\end{array}$ \\
\hline $\begin{array}{r}168-1029 \mathrm{~A}- \\
1 \mathrm{H}-5,0-5 \\
2 \mathrm{H}-6,0-5 \\
3 \mathrm{H}-6,0-5 \\
4 \mathrm{H}-6,0-5 \\
5 \mathrm{H}-5,0-5 \\
6 \mathrm{H}-6,0-5 \\
7 \mathrm{H}-6,0-5 \\
8 \mathrm{H}-5,0-5 \\
9 \mathrm{H}-6,0-5 \\
10 \mathrm{H}-5,0-5 \\
11 \mathrm{H}-6,0-5 \\
12 \mathrm{H}-4,0-5 \\
13 \mathrm{X}-3,0-5 \\
16 \mathrm{X}-3,0-5 \\
17 \mathrm{X}-3,0-5 \\
18 \mathrm{X}-3,0-5 \\
19 \mathrm{X}-3,0-5 \\
20 \mathrm{X}-3,0-5 \\
21 \mathrm{X}-3,0-5 \\
22 \mathrm{X}-6,0-5 \\
23 \mathrm{X}-6,0-5 \\
24 \mathrm{X}-6,0-5 \\
25 \mathrm{X}-2,0-5\end{array}$ & $\begin{array}{r}6.03 \\
12.03 \\
21.53 \\
31.03 \\
39.03 \\
50.03 \\
59.53 \\
67.53 \\
78.53 \\
86.53 \\
97.53 \\
104.03 \\
112.03 \\
133.43 \\
143.03 \\
152.63 \\
162.23 \\
172.83 \\
181.43 \\
195.53 \\
205.13 \\
214.73 \\
218.33\end{array}$ & $\begin{array}{r}2 \\
3 \\
3 \\
3 \\
3 \\
348 \\
1270 \\
2745 \\
3053 \\
3346 \\
2305 \\
2375 \\
1614 \\
16 \\
10 \\
11 \\
6 \\
4 \\
5 \\
5 \\
6 \\
6 \\
3\end{array}$ \\
\hline $\begin{array}{r}168-1030 \mathrm{~B}- \\
1 \mathrm{H}-2,0-5 \\
2 \mathrm{H}-6,0-5 \\
3 \mathrm{H}-6,0-5 \\
4 \mathrm{H}-6,0-5 \\
5 \mathrm{H}-6,0-5\end{array}$ & $\begin{array}{r}1.53 \\
11.53 \\
21.03 \\
30.53 \\
40.03\end{array}$ & $\begin{array}{l}2 \\
3 \\
3 \\
3 \\
2\end{array}$ \\
\hline $\begin{array}{r}168-1031 \mathrm{~A}- \\
1 \mathrm{H}-6,0-5 \\
2 \mathrm{H}-6,0-5 \\
3 \mathrm{H}-6,0-5 \\
4 \mathrm{H}-6,0-5 \\
5 \mathrm{H}-3,0-5\end{array}$ & $\begin{array}{r}7.53 \\
16.33 \\
25.83 \\
35.33 \\
40.33\end{array}$ & $\begin{array}{l}5 \\
4 \\
3 \\
3 \\
3\end{array}$ \\
\hline $\begin{array}{c}\text { 168-1032A- } \\
\text { 2R-2, 0-5 } \\
\text { 3R-2, 0-5 } \\
\text { 5R-3,0-5 } \\
\text { 6R-3, 0-5 } \\
\text { 7R-2, 0-5 } \\
8 \mathrm{R}-3,0-5 \\
10 \mathrm{R}-4,0-5\end{array}$ & $\begin{array}{l}195.63 \\
214.83 \\
225.53 \\
235.53 \\
243.63 \\
254.73 \\
275.53\end{array}$ & $\begin{array}{r}3337 \\
1774 \\
88 \\
76 \\
29 \\
71 \\
15\end{array}$ \\
\hline
\end{tabular}

This table also appears on the volume CD-ROM.

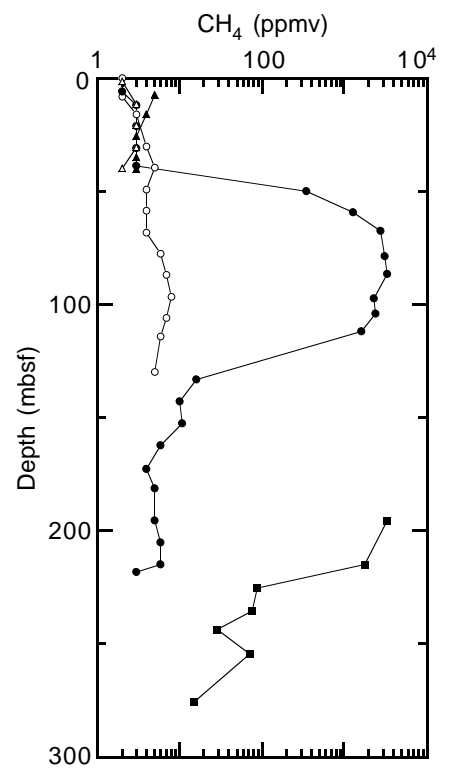

Figure 16. Profiles of methane concentration in headspace gas samples from Sites 1028, 1029, 1030, 1031, and 1032. Open circles = Hole 1028A; solid circles $=$ Hole 1029A; open triangles $=$ Hole 1030B; solid triangles $=$ Hole $1031 \mathrm{~A}$; and solid squares $=$ Hole $1032 \mathrm{~A}$.

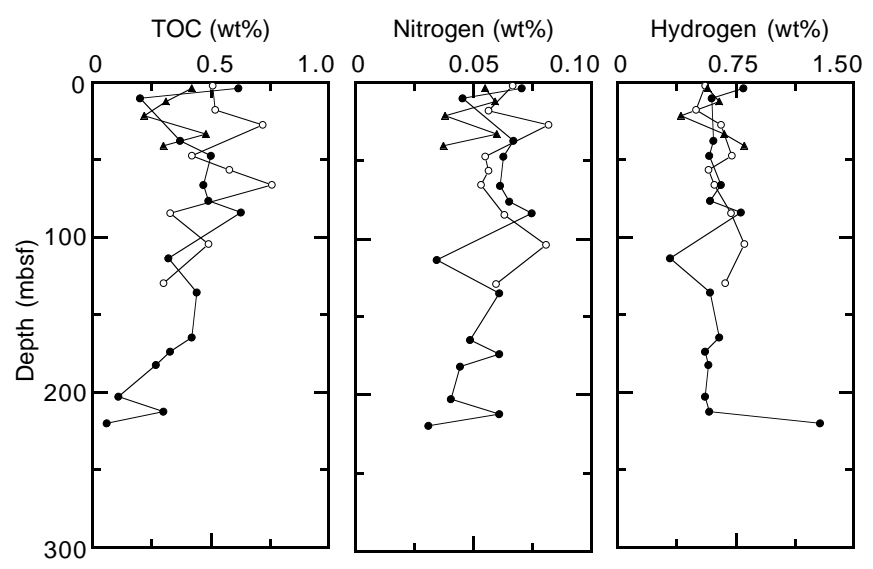

Figure 17. Depth distribution of organic carbon, total nitrogen, and total hydrogen in sediment from Sites 1028, 1029, and 1031. Open circles $=$ Hole 1028A; solid circles $=$ Hole 1029A; and solid triangles $=$ Hole 1031A.

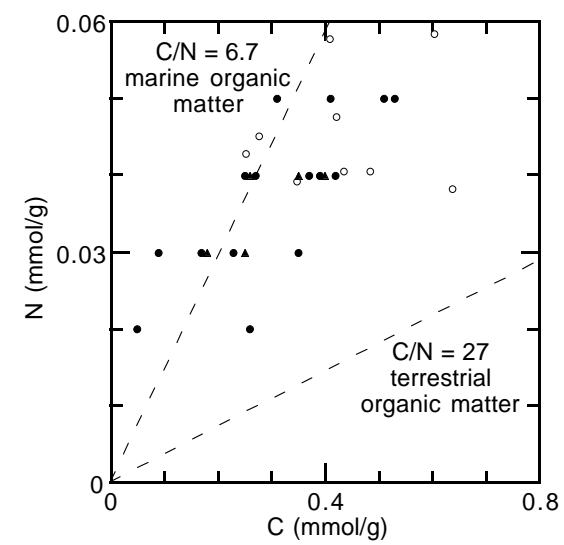

Figure 18. Total nitrogen vs. total organic carbon plotted vs. total nitrogen in sediment from Sites 1028 , 1029, and 1031. Open circles $=$ Hole 1028A; solid circles $=$ Hole 1029A; and solid triangles $=$ Hole $1031 \mathrm{~A}$. 

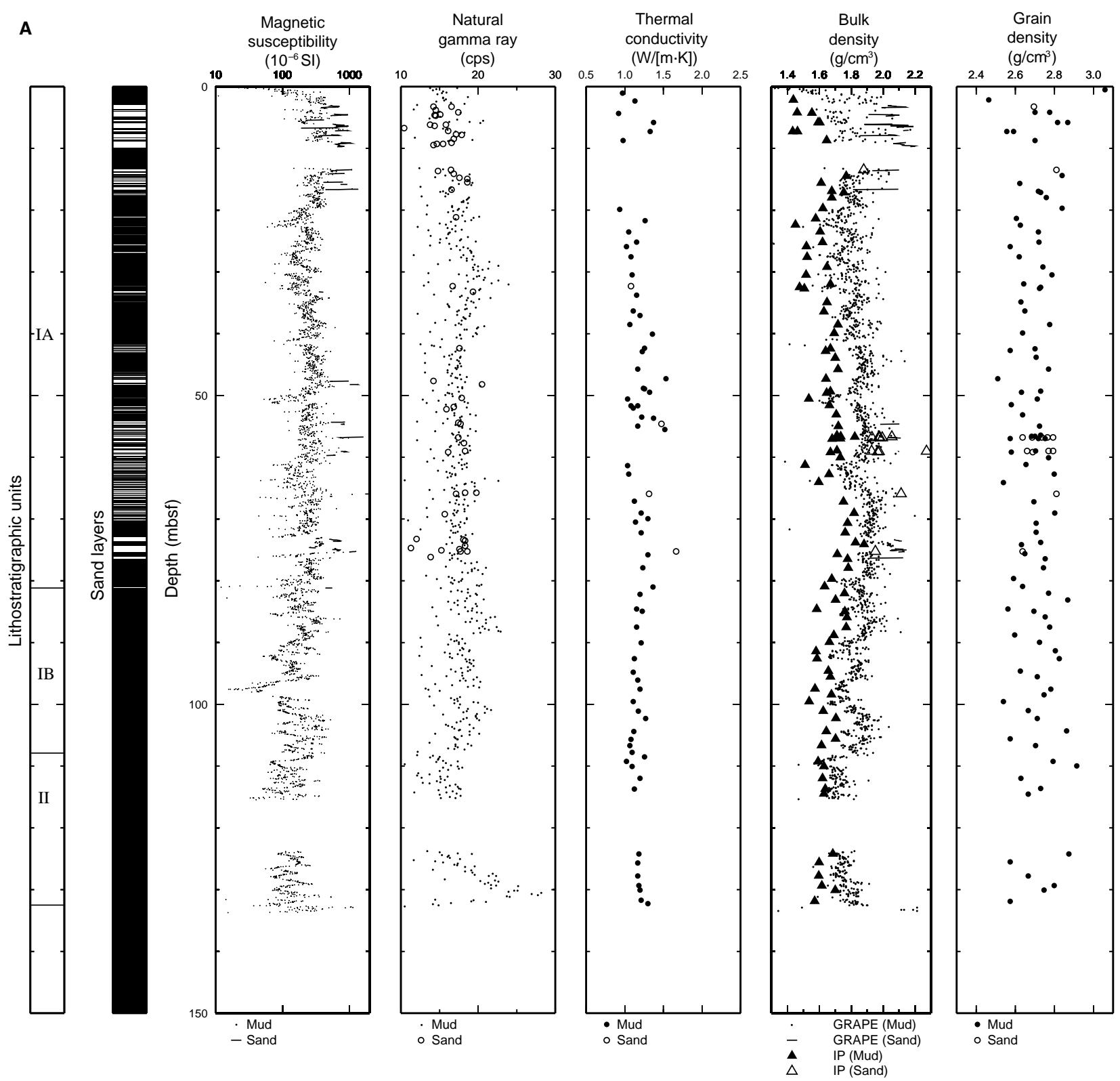

Figure 19. Summary plots for physical properties with lithostratigraphic units and identified sand (white) layers for (A) Hole 1028A, (B) Hole 1029A, (C) Hole 1030B, (D) Hole 1031A, and (E) Hole 1032A. All data points below $132.48 \mathrm{mbsf}$ in (A), 220.07 mbsf in (B), and 290.29 mbsf in (E) indicate basalt rather than sediment. 

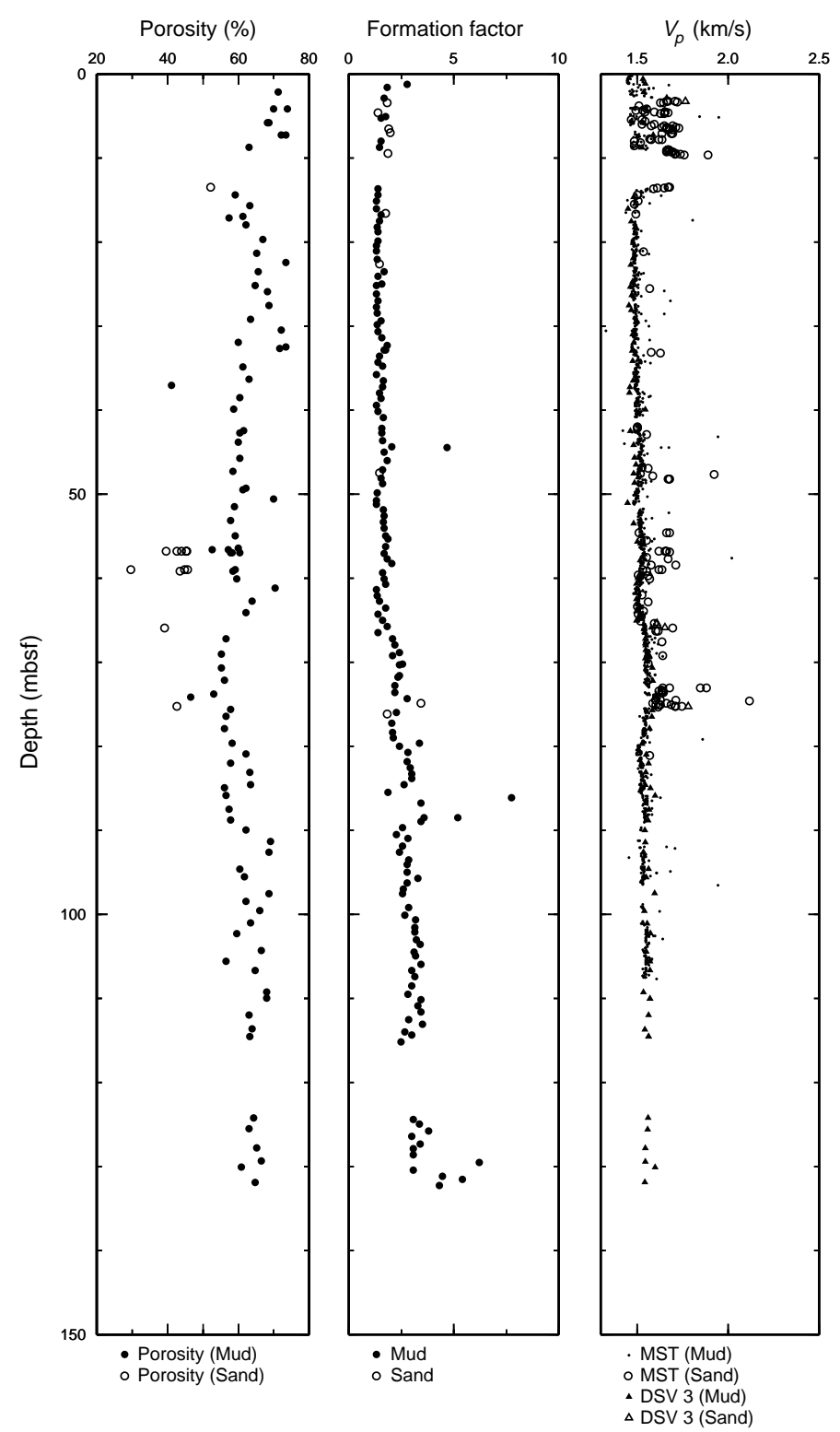

Shear strength $(\mathrm{kPa})$

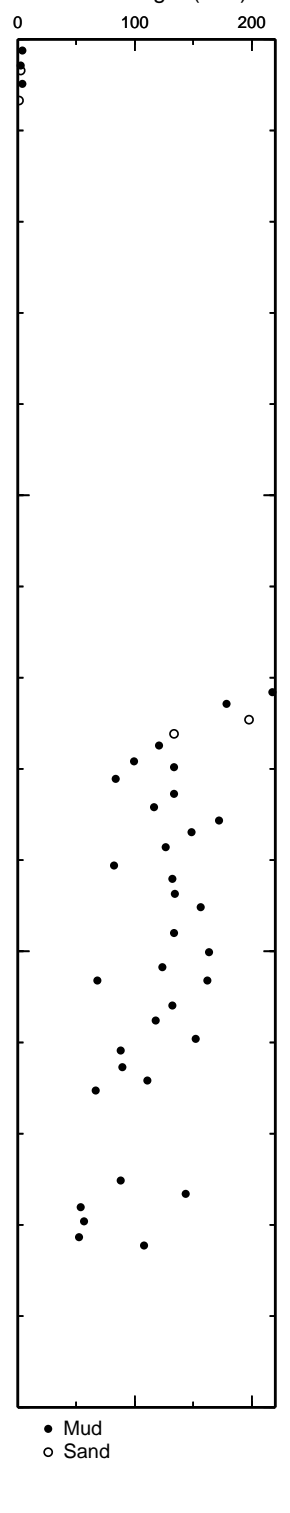

Figure 19 (continued). 

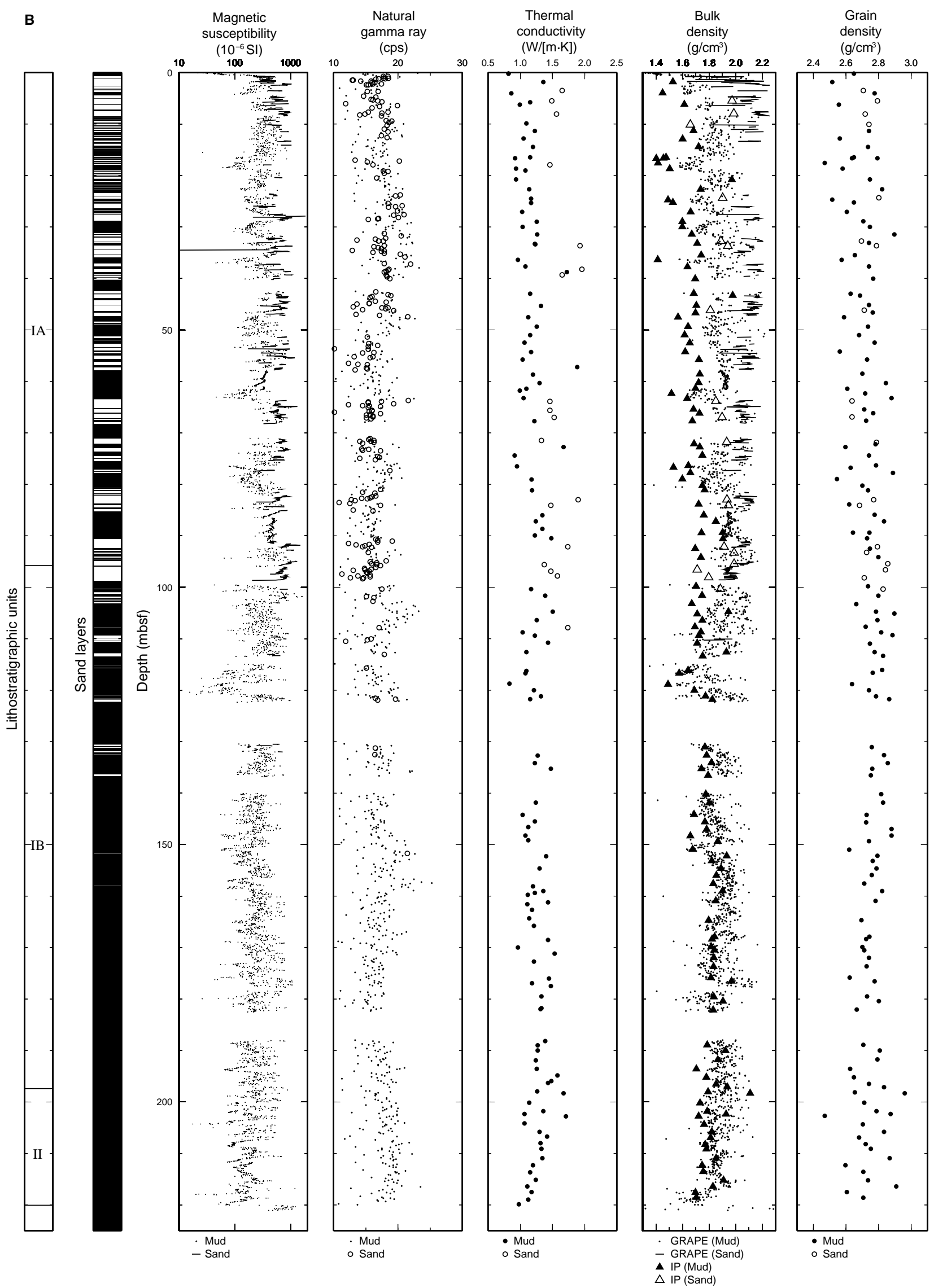

Figure 19 (continued). 


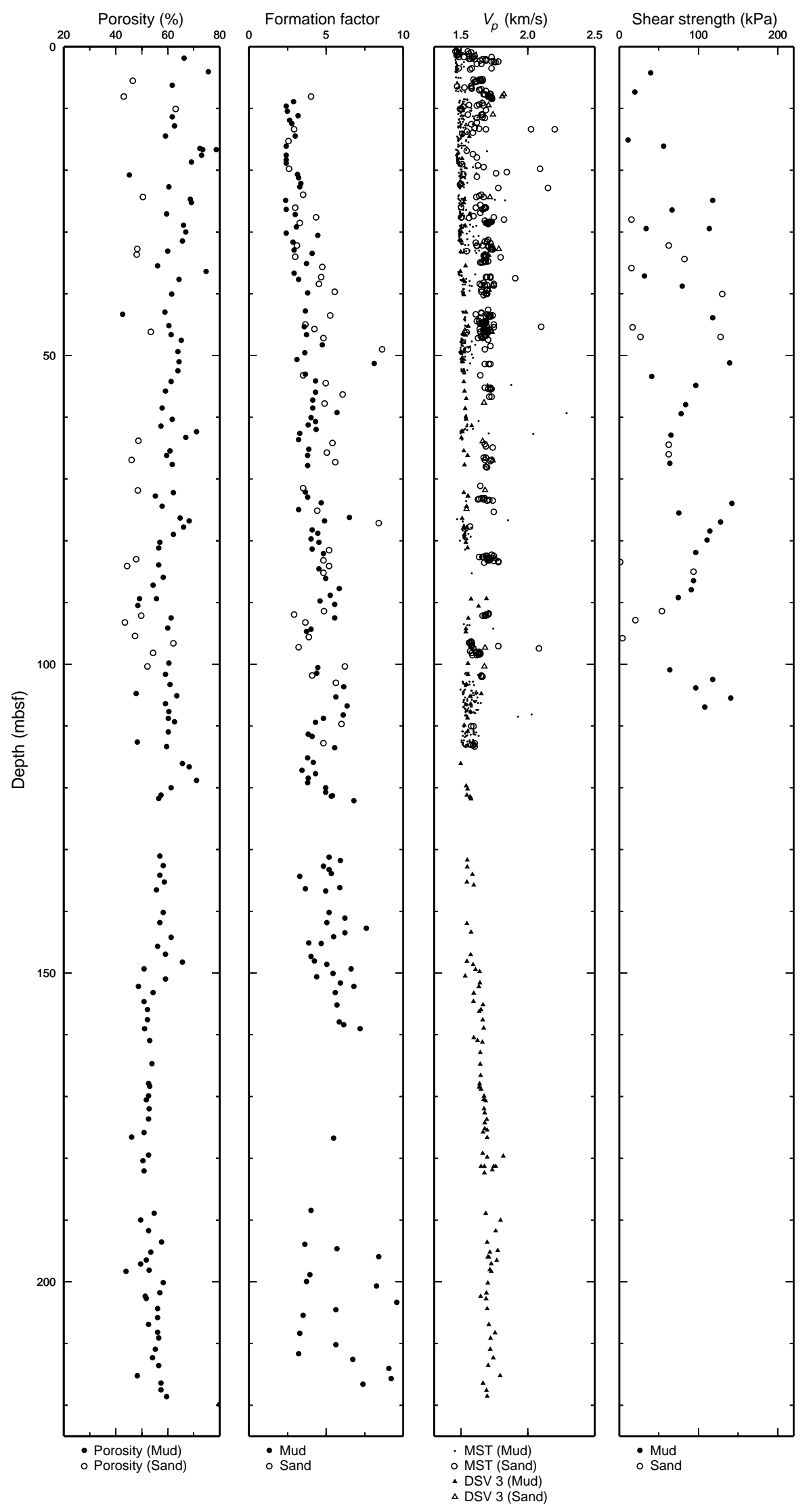

Figure 19 (continued). 
BURIED BASEMENT TRANSECT
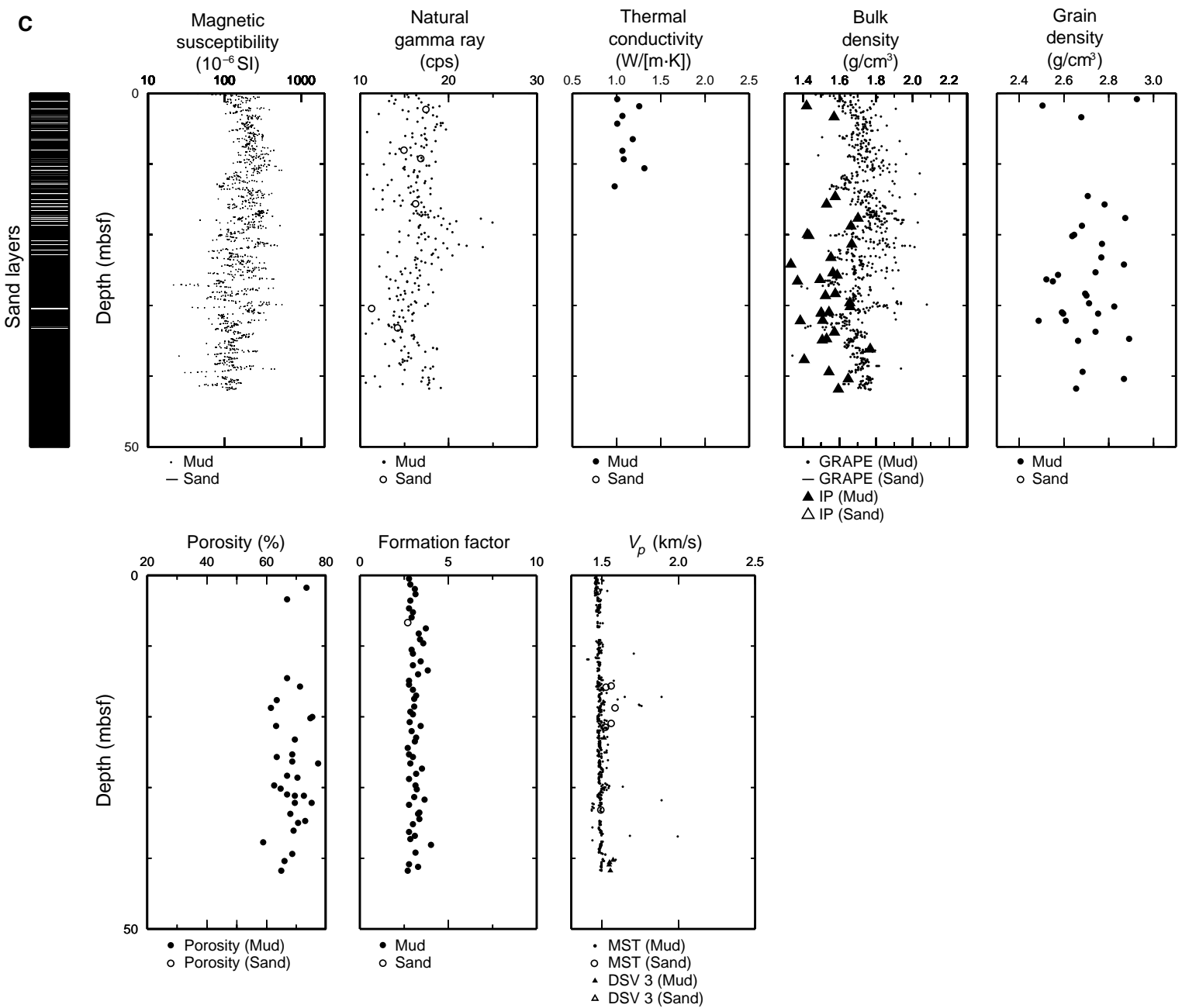

Figure 19 (continued). 

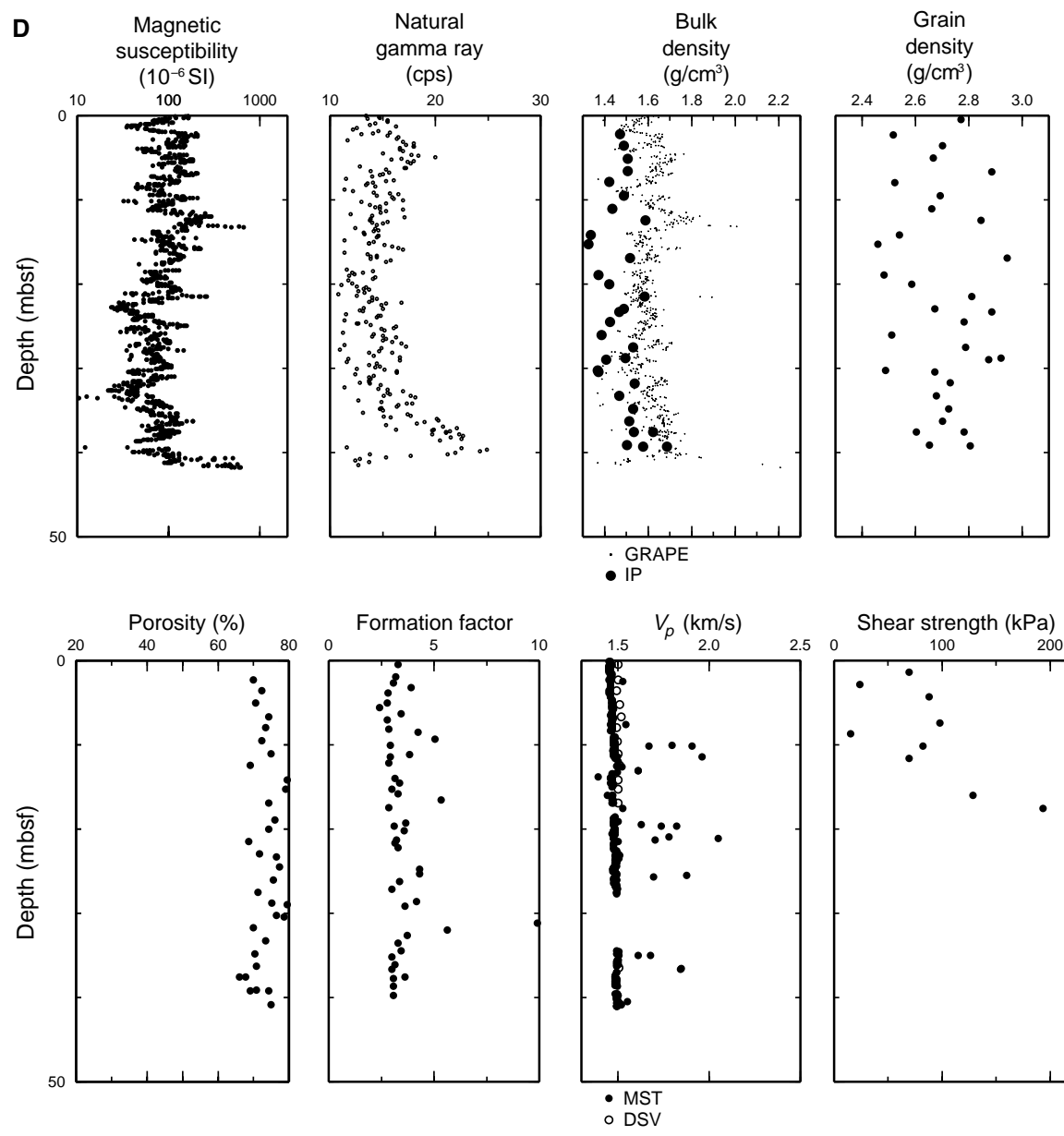

Shear strength $(\mathrm{kPa})$

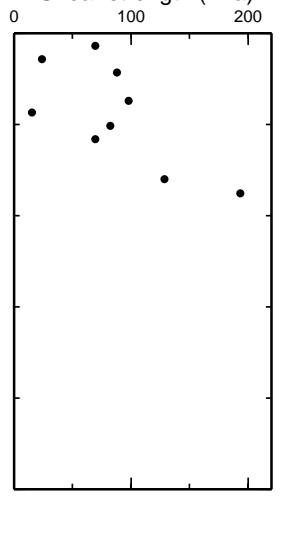

Figure 19 (continued). 
BURIED BASEMENT TRANSECT
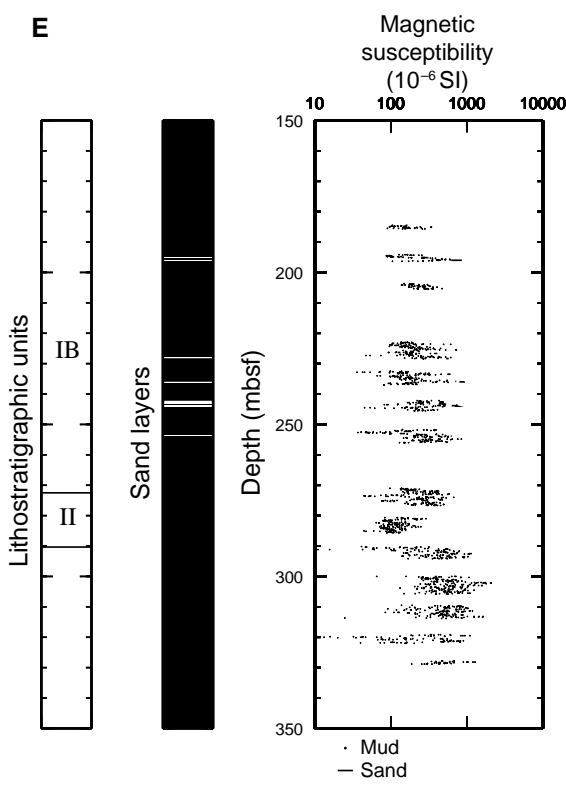

Natural
gamma ray
(cps)
$0 \quad 10^{20} \quad 30$
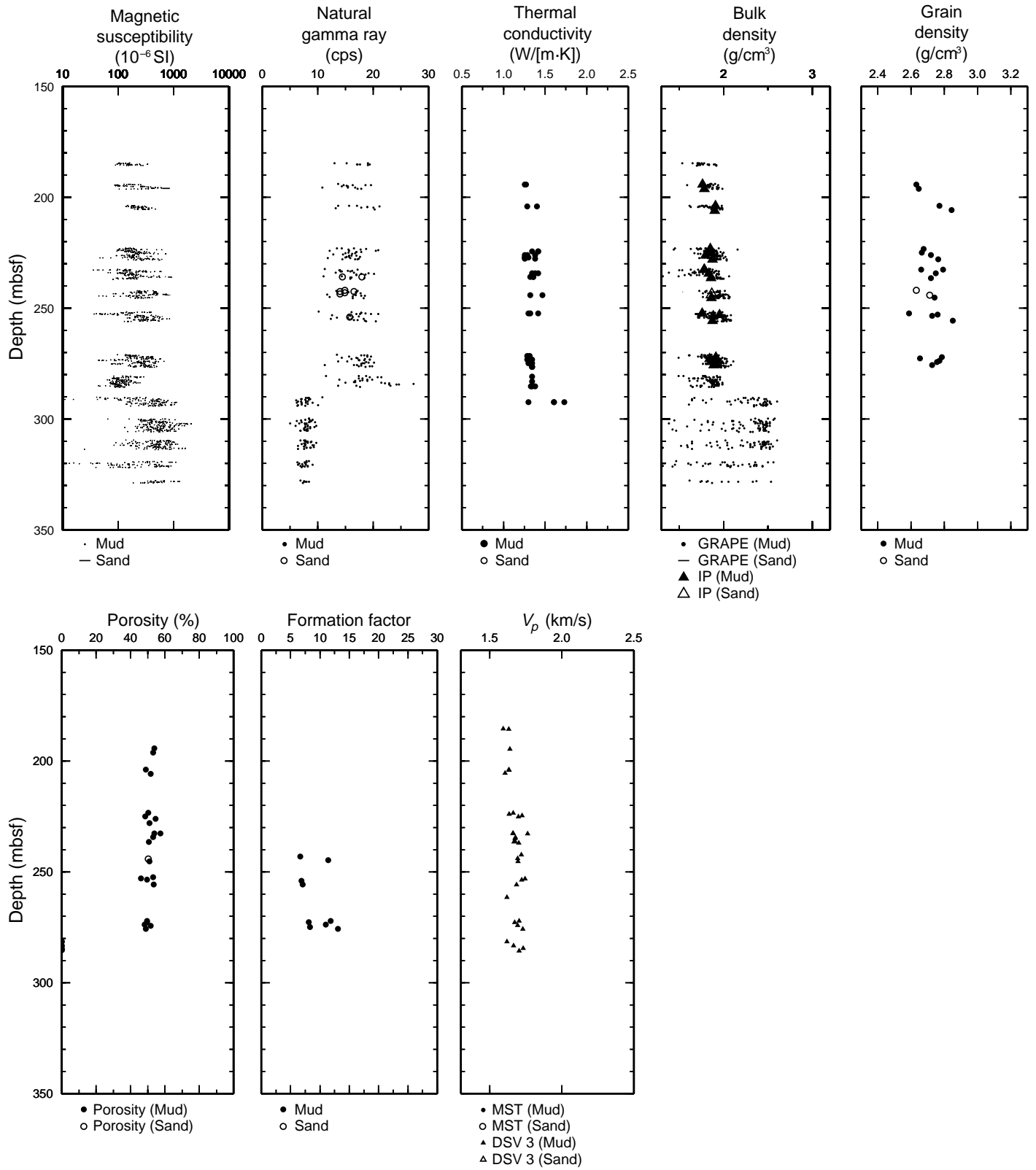

Figure 19 (continued). 
Table 13. Average physical properties values for mud and sand from Sites 1028, 1029, 1030, 1031, and 1032.

\begin{tabular}{|c|c|c|c|c|c|c|c|}
\hline & \multirow[b]{2}{*}{ Hole } & \multicolumn{3}{|c|}{ Mud } & \multicolumn{3}{|c|}{ Sand } \\
\hline & & Average & SD & $n$ & Average & SD & $n$ \\
\hline $\operatorname{MS}\left(10^{-6} \mathrm{SI}\right)$ & $\begin{array}{l}1028 \mathrm{~A} \\
1029 \mathrm{~A} \\
1030 \mathrm{~B} \\
1031 \mathrm{~A} \\
1032 \mathrm{~A}\end{array}$ & $\begin{array}{l}220 \\
300 \\
180 \\
100 \\
220\end{array}$ & $\begin{array}{r}80 \\
100 \\
70 \\
40 \\
90\end{array}$ & $\begin{array}{l}3597 \\
5132 \\
1339 \\
1309 \\
1017\end{array}$ & $\begin{array}{r}600 \\
600 \\
300 \\
600\end{array}$ & $\begin{array}{r}200 \\
200 \\
100 \\
100\end{array}$ & $\begin{array}{r}325 \\
1255 \\
38 \\
-46\end{array}$ \\
\hline GRAPE $\left(\mathrm{g} / \mathrm{cm}^{3}\right)$ & $\begin{array}{l}1028 \mathrm{~A} \\
1029 \mathrm{~A} \\
1030 \mathrm{~B} \\
1031 \mathrm{~A} \\
1032 \mathrm{~A}\end{array}$ & $\begin{array}{l}1.82 \\
1.87 \\
1.72 \\
1.61 \\
1.87\end{array}$ & $\begin{array}{l}0.08 \\
0.09 \\
0.07 \\
0.06 \\
0.09\end{array}$ & $\begin{array}{r}2103 \\
3010 \\
788 \\
754 \\
597\end{array}$ & $\begin{array}{l}2.03 \\
2.05 \\
1.9 \\
1.9\end{array}$ & $\begin{array}{l}0.09 \\
0.08 \\
0.1 \\
\overline{0.1}\end{array}$ & $\begin{array}{r}178 \\
735 \\
17 \\
28\end{array}$ \\
\hline IP density $\left(\mathrm{g} / \mathrm{cm}^{3}\right)$ & $\begin{array}{l}1028 \mathrm{~A} \\
1029 \mathrm{~A} \\
1030 \mathrm{~B} \\
1031 \mathrm{~A} \\
1032 \mathrm{~A}\end{array}$ & $\begin{array}{l}1.65 \\
1.70 \\
1.54 \\
1.47 \\
1.89\end{array}$ & $\begin{array}{l}0.08 \\
0.1 \\
0.07 \\
0.07 \\
0.08\end{array}$ & $\begin{array}{r}96 \\
136 \\
33 \\
34 \\
23\end{array}$ & $\begin{array}{l}2.0 \\
1.9 \\
\overline{-} \\
1.85\end{array}$ & $\begin{array}{l}0.2 \\
0.07 \\
\overline{-} \\
0.02\end{array}$ & $\begin{array}{r}14 \\
19 \\
- \\
-2\end{array}$ \\
\hline IP grain density $\left(\mathrm{g} / \mathrm{cm}^{3}\right)$ & $\begin{array}{l}1028 \mathrm{~A} \\
1029 \mathrm{~A} \\
1030 \mathrm{~B} \\
1031 \mathrm{~A} \\
1032 \mathrm{~A}\end{array}$ & $\begin{array}{l}2.70 \\
2.72 \\
2.70 \\
2.70 \\
2.76\end{array}$ & $\begin{array}{l}0.1 \\
0.07 \\
0.1 \\
0.2 \\
0.08\end{array}$ & $\begin{array}{r}96 \\
136 \\
33 \\
34 \\
23\end{array}$ & $\begin{array}{l}2.73 \\
2.75 \\
\overline{\bar{T}} \\
2.67\end{array}$ & $\begin{array}{l}0.06 \\
0.05 \\
\overline{\bar{C}} \\
0.04\end{array}$ & $\begin{array}{r}14 \\
19 \\
- \\
-2\end{array}$ \\
\hline IP porosity $(\%)$ & $\begin{array}{l}1028 \mathrm{~A} \\
1029 \mathrm{~A} \\
1030 \mathrm{~B} \\
1031 \mathrm{~A} \\
1032 \mathrm{~A}\end{array}$ & $\begin{array}{l}62 \\
59 \\
69 \\
73 \\
50\end{array}$ & $\begin{array}{l}5 \\
6 \\
4 \\
3 \\
3\end{array}$ & $\begin{array}{r}96 \\
136 \\
33 \\
34 \\
23\end{array}$ & $\begin{array}{c}43 \\
50 \\
- \\
\overline{49.8}\end{array}$ & $\begin{array}{l}3 \\
\frac{4}{E} \\
\overline{0.3}\end{array}$ & $\begin{array}{r}13 \\
19 \\
- \\
-2\end{array}$ \\
\hline Therm. cond. $(\mathrm{W} /[\mathrm{m} \cdot \mathrm{K}])$ & $\begin{array}{l}1028 \mathrm{~A} \\
1029 \mathrm{~A} \\
1032 \mathrm{~A}\end{array}$ & $\begin{array}{l}1.20 \\
1.20 \\
1.20\end{array}$ & $\begin{array}{l}0.10 \\
0.10 \\
0.06\end{array}$ & $\begin{array}{r}74 \\
123 \\
46\end{array}$ & $\begin{array}{l}1.4 \\
1.6 \\
-\end{array}$ & $\begin{array}{l}0.2 \\
0.2 \\
-\end{array}$ & $\begin{array}{r}4 \\
18 \\
-\end{array}$ \\
\hline PWL $(\mathrm{km} / \mathrm{s})$ & $\begin{array}{l}1028 \mathrm{~A} \\
1029 \mathrm{~A} \\
1030 \mathrm{~B} \\
1031 \mathrm{~A}\end{array}$ & $\begin{array}{l}1.52 \\
1.53 \\
1.49 \\
1.49\end{array}$ & $\begin{array}{l}0.03 \\
0.04 \\
0.02 \\
0.03\end{array}$ & $\begin{array}{r}1335 \\
698 \\
551 \\
421\end{array}$ & $\begin{array}{l}1.62 \\
1.67 \\
1.53 \\
-\end{array}$ & $\begin{array}{l}0.07 \\
0.07 \\
0.03 \\
-\end{array}$ & $\begin{array}{r}137 \\
344 \\
7 \\
-\end{array}$ \\
\hline $\operatorname{DSV}(\mathrm{km} / \mathrm{s})$ & $\begin{array}{l}1028 \mathrm{~A} \\
1029 \mathrm{~A} \\
1030 \mathrm{~B} \\
1031 \mathrm{~A} \\
1032 \mathrm{~A}\end{array}$ & $\begin{array}{l}1.60 \\
1.62 \\
1.55 \\
1.50 \\
1.68\end{array}$ & $\begin{array}{l}0.1 \\
0.07 \\
0.01 \\
0.01 \\
0.03\end{array}$ & $\begin{array}{r}118 \\
162 \\
5 \\
13 \\
33\end{array}$ & $\begin{array}{l}1.70 \\
1.70 \\
- \\
-\end{array}$ & $\begin{array}{l}0.07 \\
0.05 \\
- \\
-\end{array}$ & $\begin{array}{r}4 \\
20 \\
- \\
-\end{array}$ \\
\hline NGR (cps) & $\begin{array}{l}1028 \mathrm{~A} \\
1029 \mathrm{~A} \\
1030 \mathrm{~B} \\
1031 \mathrm{~A} \\
1032 \mathrm{~A}\end{array}$ & $\begin{array}{l}17 \\
17 \\
16 \\
15 \\
17\end{array}$ & $\begin{array}{l}2 \\
2 \\
2 \\
2 \\
2\end{array}$ & $\begin{array}{l}674 \\
972 \\
255 \\
248 \\
190\end{array}$ & $\begin{array}{l}16 \\
16 \\
15 \\
15\end{array}$ & $\begin{array}{l}2 \\
2 \\
2 \\
2\end{array}$ & $\begin{array}{r}55 \\
227 \\
6 \\
-8\end{array}$ \\
\hline $\mathrm{FF}$ & $\begin{array}{l}1028 \mathrm{~A} \\
1029 \mathrm{~A} \\
1030 \mathrm{~B} \\
1031 \mathrm{~A} \\
1032 \mathrm{~A}\end{array}$ & $\begin{array}{l}2.25 \\
4.69 \\
3.10 \\
3.56 \\
9.37\end{array}$ & $\begin{array}{l}0.90 \\
1.6 \\
0.30 \\
1.15 \\
2.45\end{array}$ & $\begin{array}{r}154 \\
141 \\
56 \\
47 \\
9\end{array}$ & $\begin{array}{c}2.83 \\
5.43 \\
\overline{12.18} \\
-\end{array}$ & $\begin{array}{l}2.00 \\
2.60 \\
= \\
-\end{array}$ & $\begin{array}{r}10 \\
50 \\
- \\
-1\end{array}$ \\
\hline
\end{tabular}

Notes: $\mathrm{SD}=$ standard deviation, and $n=$ number. $-=$ no samples. Measurements are for magnetic susceptibility (MS), bulk density from GRAPE and index properties (IP) measurements, IP grain density and porosity, thermal conductivity (Therm. cond.), $P$-wave velocities from the MST (PWL) and DSV, natural gamma-ray activity (NGR), and formation factor (FF) from electrical resistivity.

Table 14. The number of measurements for identified sand samples relative to the total number of measurements in comparison with the total thickness of sand layers relative to the depth of drilled section.

\begin{tabular}{lcccc}
\hline Measurement type & $\begin{array}{c}\text { Hole 1028A } \\
\text { (\% sand) }\end{array}$ & $\begin{array}{c}\text { Hole 1029A } \\
\text { (\% sand) }\end{array}$ & $\begin{array}{c}\text { Hole 1030B } \\
\text { (\% sand) }\end{array}$ & $\begin{array}{c}\text { Hole 1032A } \\
\text { (\% sand) }\end{array}$ \\
\hline Sand (full hole) & 7.99 & 18.12 & 2.81 & 4.23 \\
GRAPE & 7.80 & 19.62 & 2.11 & 4.48 \\
MS & 8.29 & 19.65 & 2.75 & 4.33 \\
NGR & 7.54 & 18.93 & 2.30 & 4.04 \\
PWL & 9.31 & 33.01 & 1.25 & - \\
DSV & 3.28 & 10.98 & 0 & 0 \\
IP & 12.73 & 12.26 & 0 & 8 \\
TC & 4.05 & 13.38 & - & -0 \\
FF & 6.10 & 26.18 & 0 & 0 \\
\hline
\end{tabular}

Notes: Measurements: GRAPE $=$ gamma-ray attenuation porosity evaluator; $\mathrm{MS}=$ magnetic susceptibility; NGR $=$ natural gamma-ray activity; $\mathrm{PWL}=P$-wave logger; $\mathrm{DSV}=$ digital sonic velocimeter; $\mathrm{IP}=$ index properties; $\mathrm{TC}=$ thermal conductivity; and $\mathrm{FF}=$ formation factor. $-=$ no measurements.

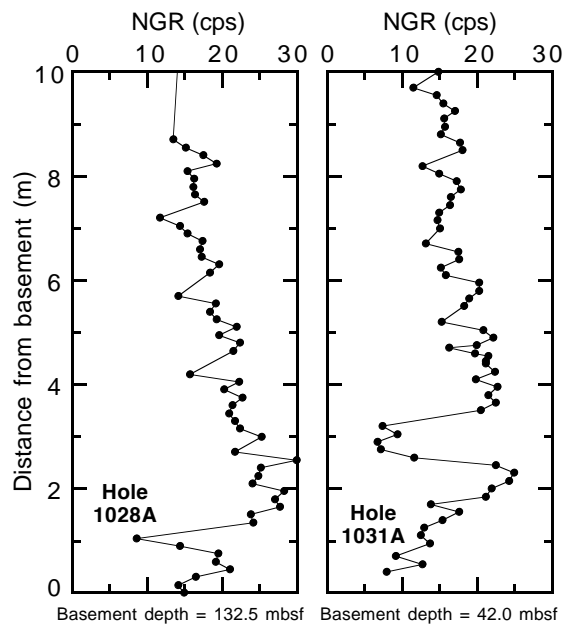

Figure 20. Natural gamma-ray profiles plotted with respect to distance from basement. 
Figure 21. Fine-scale variations in index properties of two turbidites from Hole 1028A. A. 58.8-59.4 mbsf. B. 56.457.0 mbsf. Bulk density (open circles), porosity (solid squares), and grain density (solid circles) are plotted with respect to depth. Solid horizontal lines mark bottom turbidite boundaries. Dashed horizontal lines mark the apparent turbidite tops. No systematic sequence of properties is apparent.

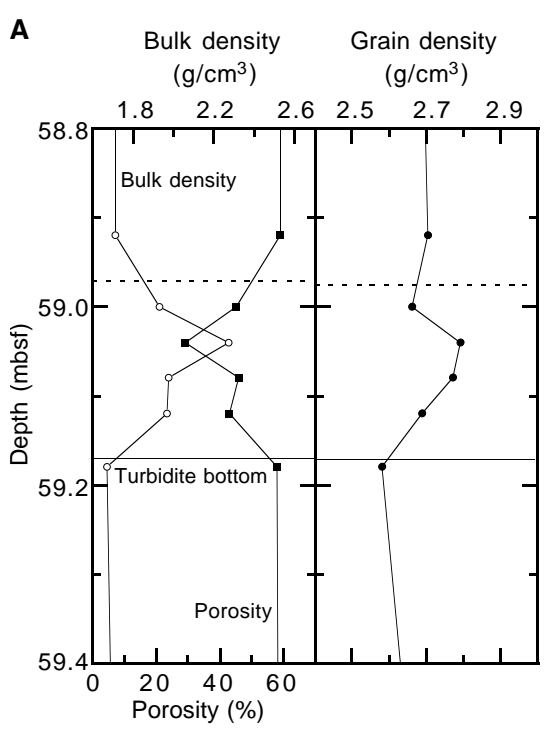

B Bulk density Grain density $\left(\mathrm{g} / \mathrm{cm}^{3}\right)$ $\left(\mathrm{g} / \mathrm{cm}^{3}\right)$

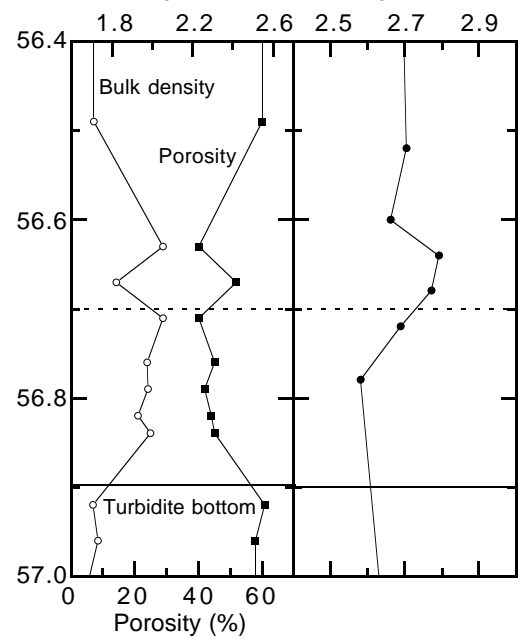

Thermal conductivity

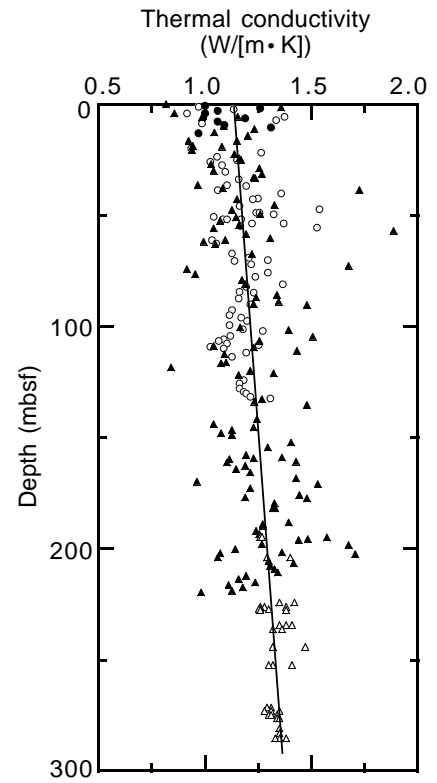

Figure 23. Sediment thermal conductivity profile from Holes 1028A (open circles), 1029A (solid triangles), 1030B (solid circles), and 1032A (open triangles). All data from Holes 1028A, 1029A, and 1030B were collected using the ThermCon 85 needle probe; Hole 1032A values were acquired with the TK04 half-space line source.

Figure 24. Porosity vs. thermal conductivity for mud (open symbols) and sand (solid symbols). Data are from Holes 1028A (circles), 1029B (squares), and $1032 \mathrm{~A}$ (diamonds). The lines indicate theoretical values based on the geometric mean mixing model. The curve parameter is the matrix thermal conductivity in $\mathrm{W} /(\mathrm{m} \cdot \mathrm{K})$. 
Table 17. Extrapolated equilibrium temperatures from APC tool and DVTP deployments along the Buried Basement Transect.

\begin{tabular}{|c|c|c|c|c|c|c|}
\hline \multirow[b]{2}{*}{ Core } & \multirow[b]{2}{*}{ Tool } & \multirow[b]{2}{*}{$\begin{array}{c}\text { Depth } \\
\text { (mbsf) }\end{array}$} & \multirow[b]{2}{*}{$\begin{array}{l}\text { Error }^{\mathrm{a}} \\
\text { (mbsf) }\end{array}$} & \multicolumn{3}{|c|}{ Extrapolated equilibrium temperature $\left({ }^{\circ} \mathrm{C}\right)^{\mathrm{b}}$} \\
\hline & & & & $\begin{array}{c}\lambda=1.1 \\
(\mathrm{~W} /[\mathrm{m} \cdot \mathrm{K}])\end{array}$ & $\begin{array}{c}\lambda=1.0 \\
(\mathrm{~W} /[\mathrm{m} \cdot \mathrm{K}])\end{array}$ & $\begin{array}{c}\lambda=1.5 \\
(\mathrm{~W} /[\mathrm{m} \cdot \mathrm{K}])\end{array}$ \\
\hline $\begin{array}{c}168-1028 \mathrm{~A}- \\
4 \mathrm{H} \\
6 \mathrm{H} \\
8 \mathrm{H} \\
10 \mathrm{H} \\
13 \mathrm{X} \\
15 \mathrm{X}\end{array}$ & $\begin{array}{l}\text { A11 } \\
\text { A11 } \\
\text { A11 } \\
\text { A11 } \\
\text { DVTP } \\
\text { DVTP }\end{array}$ & $\begin{array}{r}32.2 \\
51.2 \\
70.2 \\
89.2 \\
109.2 \\
124.8\end{array}$ & $\begin{array}{l}1.0 \\
1.0 \\
1.0 \\
1.0 \\
1.0 \\
1.0\end{array}$ & $\begin{array}{l}14.44 \\
20.77 \\
27.87 \\
34.70 \\
42.94 \\
48.67\end{array}$ & $\begin{array}{l}14.46 \\
20.87 \\
28.05 \\
34.73 \\
42.94 \\
48.67\end{array}$ & $\begin{array}{l}14.49 \\
20.52 \\
27.36 \\
34.41 \\
42.94 \\
48.67\end{array}$ \\
\hline $\begin{array}{l}168-1029 \mathrm{~A}- \\
4 \mathrm{H} \\
6 \mathrm{H} \\
8 \mathrm{H} \\
10 \mathrm{H} \\
12 \mathrm{H} \\
16 \mathrm{X} \\
19 \mathrm{X} \\
22 \mathrm{X} \\
24 \mathrm{X}\end{array}$ & $\begin{array}{l}\text { A11 } \\
\text { A11 } \\
\text { A11 } \\
\text { A11 } \\
\text { A11 } \\
\text { DVTP } \\
\text { DVTP } \\
\text { DVTP } \\
\text { DVTP }\end{array}$ & $\begin{array}{r}33.0 \\
52.0 \\
71.0 \\
90.0 \\
109.0 \\
131.4 \\
160.2 \\
189.0 \\
208.2\end{array}$ & $\begin{array}{l}5.0 \\
5.0 \\
5.0 \\
5.0 \\
5.0 \\
1.0 \\
1.0 \\
1.0 \\
1.0\end{array}$ & $\begin{array}{l}12.57 \\
14.21 \\
18.05 \\
22.59 \\
28.29 \\
35.45 \\
42.98 \\
50.44 \\
55.85\end{array}$ & $\begin{array}{l}12.57 \\
14.68 \\
18.46 \\
22.86 \\
28.57 \\
35.45 \\
42.98 \\
50.44 \\
55.85\end{array}$ & $\begin{array}{l}12.52 \\
12.41 \\
16.83 \\
21.75 \\
27.36 \\
35.46 \\
42.99 \\
50.45 \\
55.86\end{array}$ \\
\hline $\begin{array}{l}\text { 168-1030B- } \\
6 \mathrm{X}\end{array}$ & DVTP & 42.0 & 1.0 & 36.18 & 36.18 & 36.19 \\
\hline $\begin{array}{l}168-1031 \mathrm{~A}- \\
3 \mathrm{H} \\
4 \mathrm{H} \\
5 \mathrm{H}\end{array}$ & $\begin{array}{l}\text { A11 } \\
\text { A13 } \\
\text { DVTP }\end{array}$ & $\begin{array}{l}27.8 \\
37.3 \\
38.3\end{array}$ & $\begin{array}{l}1.0 \\
1.0 \\
1.0\end{array}$ & $\begin{array}{l}29.03 \\
36.49 \\
37.60\end{array}$ & 二 & 二 \\
\hline $\begin{array}{l}168-1032 \mathrm{~A}- \\
2 \mathrm{R} \\
4 \mathrm{R} \\
7 \mathrm{R} \\
9 \mathrm{R} \\
11 \mathrm{R} \\
12 \mathrm{R}\end{array}$ & $\begin{array}{l}\text { DVTP } \\
\text { DVTP } \\
\text { DVTP } \\
\text { DVTP } \\
\text { DVTP } \\
\text { DVTP }\end{array}$ & $\begin{array}{l}195.1 \\
214.3 \\
243.1 \\
262.4 \\
281.6 \\
291.2\end{array}$ & $\begin{array}{l}1.0 \\
1.0 \\
1.0 \\
1.0 \\
1.0 \\
1.0\end{array}$ & $\begin{array}{l}35.20 \\
40.86 \\
46.28 \\
50.53 \\
55.13 \\
56.20\end{array}$ & $\begin{array}{l}-\overline{40.87} \\
46.28 \\
50.53 \\
55.13 \\
56.23\end{array}$ & $\begin{array}{l}-\overline{-} \\
46.86 \\
50.27 \\
55.12 \\
56.20\end{array}$ \\
\hline
\end{tabular}

Notes: Tools: A11 = APC tool 11; A13 = APC tool 13; and DVTP $=$ Davis/Villinger Temperature Probe. $-=$ data not processed.

${ }^{a}$ Depth error assumed to be no less than the uncertainty of individual depths because of pipe stretch and tides (1.0 m) or as much as the difference between core length and recovery for APC cores that failed to "stroke out" completely during deployment.

${ }^{b} \mathrm{~A}$ range of equilibrium temperatures is shown based on the assumed thermal conductivity of the sediments surrounding the probe tip. The range in final temperatures illustrates the minimum uncertainty in final temperatures. See text for discussion. The extrapolated temperatures determined using a sediment thermal conductivity of $1.1 \mathrm{~W} /(\mathrm{m} \cdot \mathrm{K}) \mathrm{were}$ used in subsequent calculations. Only calculations with a thermal conductivity of $1.1 \mathrm{~W} /(\mathrm{m} \cdot \mathrm{K})$ were made for measurements $168-1031 \mathrm{~A}-3 \mathrm{H}, 4 \mathrm{H}, 5 \mathrm{H}$ and $1032 \mathrm{~A}-2 \mathrm{R}$ because poor data quality did not justify additional calculations.
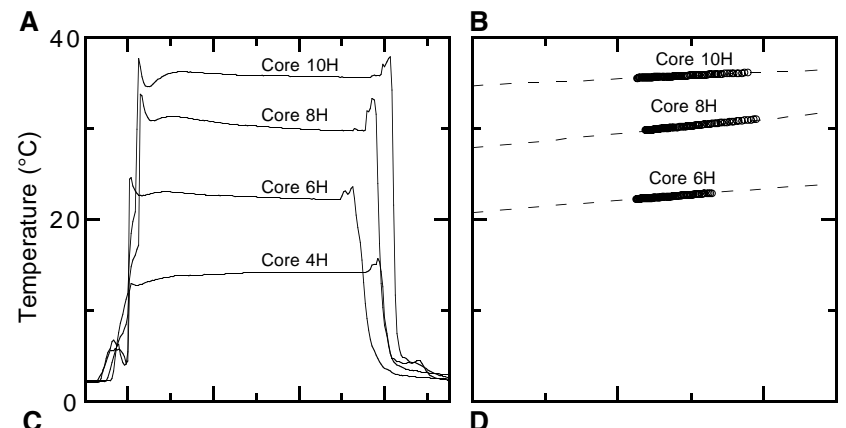

C

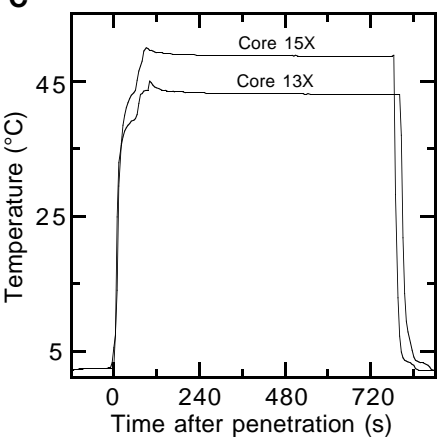

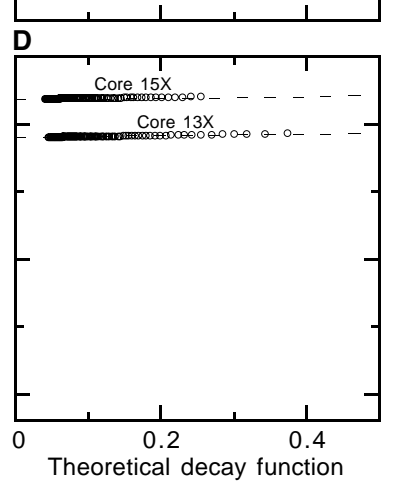

Figure 25. Temperature vs. time and temperature vs. theoretical decay functions for all tool deployments in Hole 1028A. A. Temperature vs. time following tool penetration for APC tool 11. B. Temperature vs. the APC tool theoretical decay function, showing selected observations (circles) and extrapolated final temperatures (intersection of dashed lines with ordinate). C. Temperature vs. time following tool penetration for the DVTP. D. Temperature vs. the DVTP theoretical decay function, showing selected observations (circles) and extrapolated final temperatures (intersection of dashed lines with ordinate). 

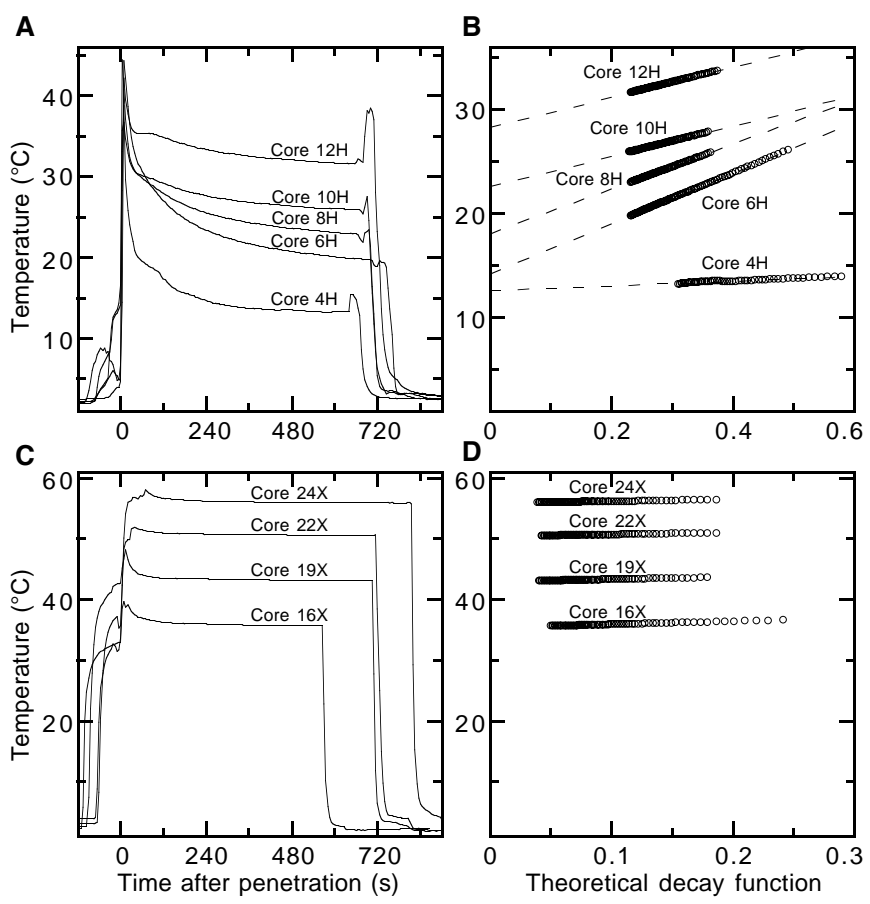

Figure 26. Temperature vs. time and temperature vs. theoretical decay functions for all tool deployments in Hole 1029A. Symbols as in Figure 25. A. Temperature vs. time following tool penetration for APC tool 11. B. Temperature vs. the APC tool theoretical decay function. C. Temperature vs. time following tool penetration for the DVTP. D. Temperature vs. the DVTP theoretical decay function.
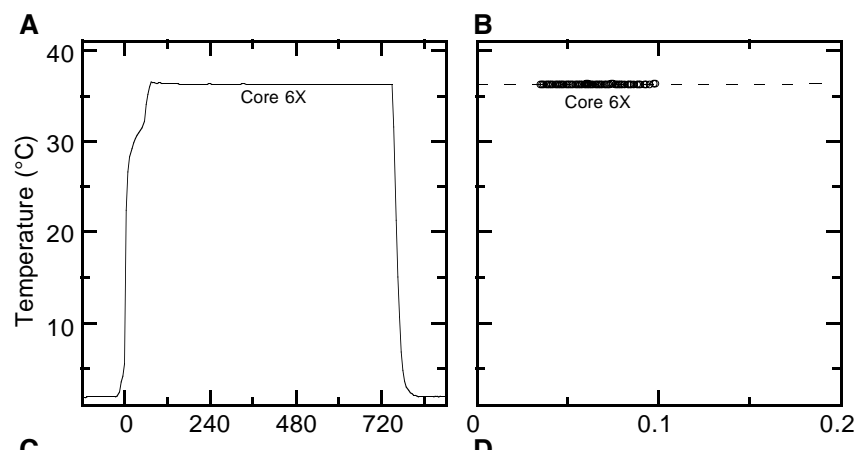

C
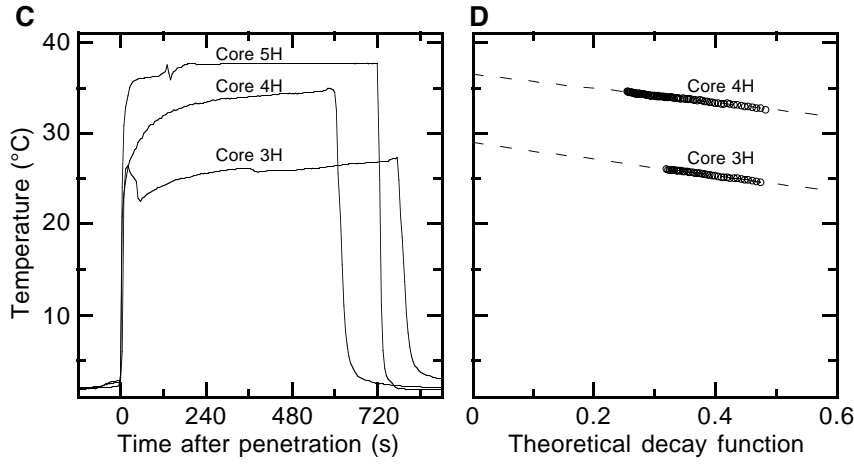

Figure 27. Temperature vs. time and temperature vs. theoretical decay functions for tool deployments in Holes 1030B and 1031A. Symbols as in Figure 25. A. Temperature vs. time following tool penetration for DVTP deployment in Hole 1030B. B. Temperature vs. the DVTP theoretical decay function. C. Temperature vs. time following tool penetration in Hole 1031 A of APC tools 11 and 13 (runs 168-1031A-3H and 4H) and the DVTP (run 168-1031A-5H). D. Temperature vs. the APC tool and DVTP theoretical decay functions.
A

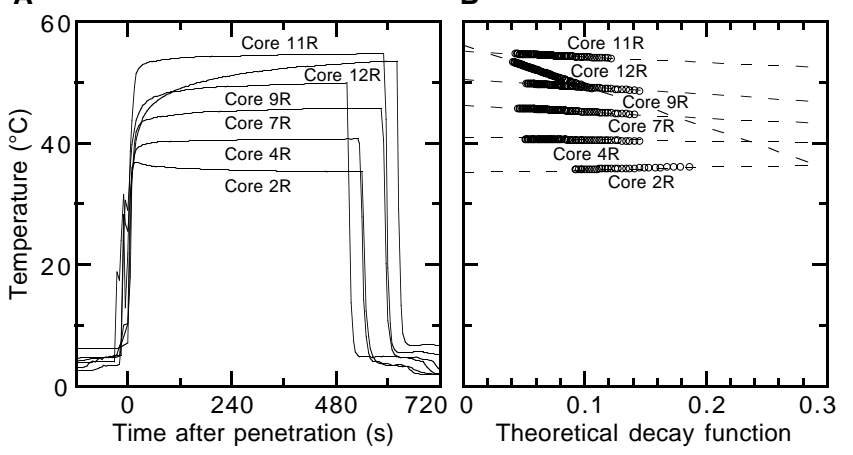

Figure 28. Temperature vs. time and temperature vs. theoretical decay functions for DVTP deployments in Hole 1032A. Symbols as in Figure 25. A. Temperature vs. time following tool penetration for DVTP deployments. B. Temperature vs. the DVTP theoretical decay function.
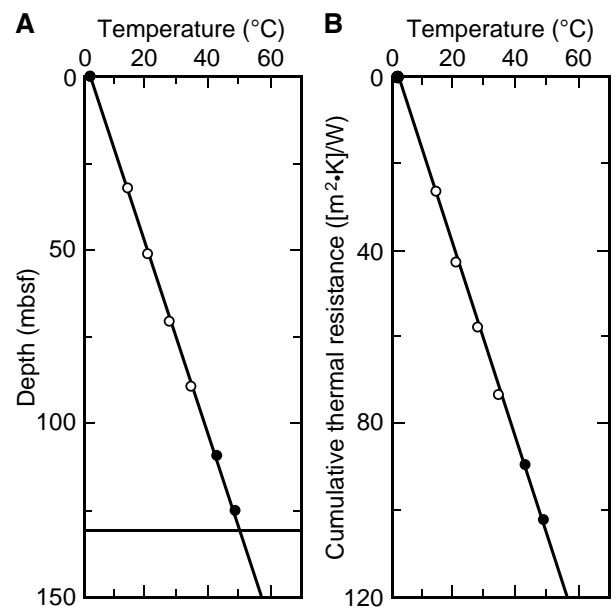

Figure 29. A. Equilibrium temperatures vs. depth within Hole 1028A. Open circles $=$ APC tool data; solid circles $=$ DVTP data. The range in estimated temperatures shown in Table 17 (based on different assumed thermal conductivities) is generally smaller than the symbols used to represent final temperature values. The subvertical line is the least-squares best fit of all data, including a bottom-water temperature of $1.85^{\circ} \mathrm{C}$ at the seafloor. The horizontal line indicates the depth to basement. B. Bullard plot showing heat flow in Hole 1028A, with cumulative thermal resistance calculated using a lithology-weighted harmonic mean model. The line is the least-squares best fit of all data, including a bottom-water temperature of $1.85^{\circ} \mathrm{C}$ at the seafloor. 
A
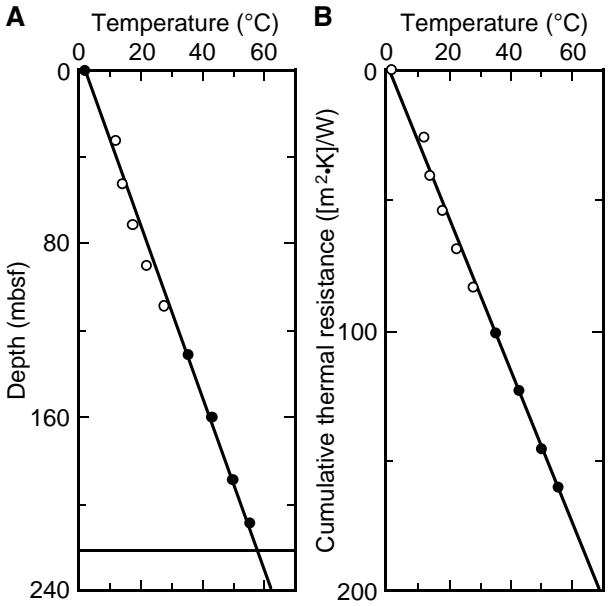

Figure 30. A. Equilibrium temperatures vs. depth within Hole 1029A. Symbols as in Figure 29. The subvertical line is the least-squares best fit of DVTP data. The horizontal line indicates the depth to basement. B. Bullard Plot showing heat flow in Hole 1029A, with cumulative thermal resistance calculated using a lithology-weighted harmonic mean model. The line is the least-squares best fit of DVTP data.
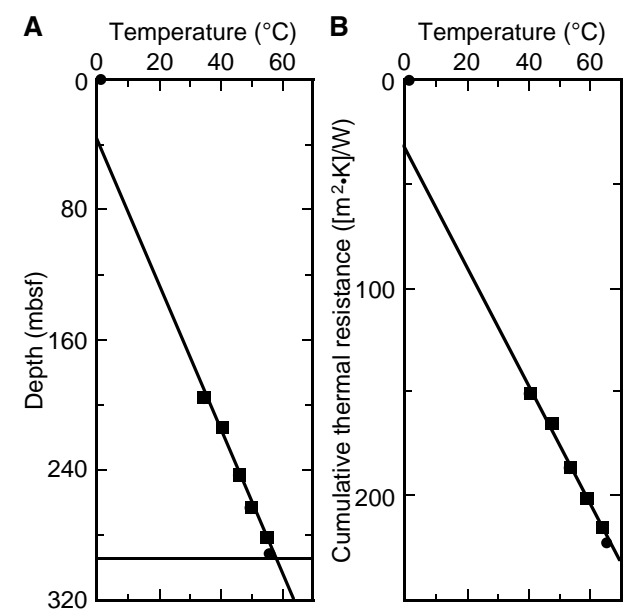

Figure 32. A. Equilibrium temperatures vs. depth within Hole 1032A. All data were collected with the DVTP; only estimated temperatures (shown as solid squares) were used to calculate the thermal gradient. The subvertical line is the least-squares best fit of selected data. The horizontal line indicates the depth to basement. B. Bullard plot showing heat flow in Hole 1032A, with cumulative thermal resistance calculated using a lithology-weighted harmonic mean model. The line is the least-squares best fit of selected data.

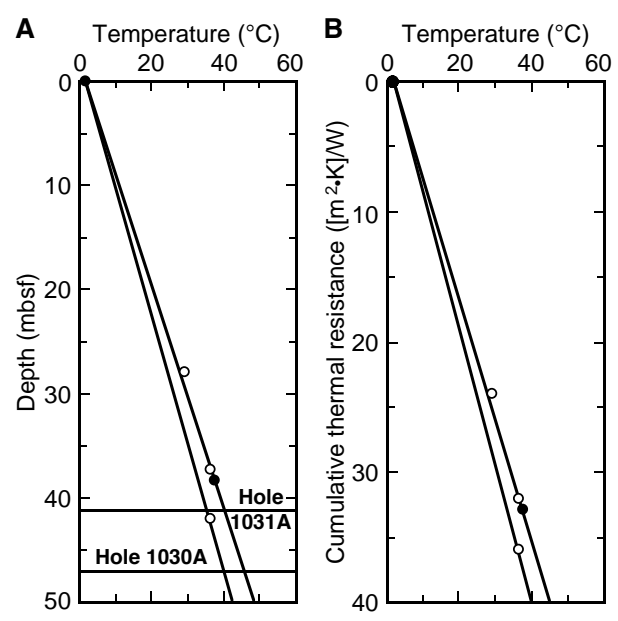

Figure 31. A. Equilibrium temperatures vs. depth within Holes 1030B and 1031A. Symbols as in Figure 29. Data from Hole 1030B include a single estimated sediment temperature and bottom-water temperature. The shallowest APC tool measurement in Hole 1031A was considered to be unreliable and was not used in subsequent calculations. Subvertical lines are the leastsquares best fit of the selected data. Horizontal lines indicate the depths to basement, as marked. B. Bullard plot showing heat flow in Holes 1030B and 1031A, with cumulative thermal resistance calculated using a lithologyweighted harmonic mean model. The lines are least-squares best fits of selected data. Solid circles $=$ DVTP data and open circles $=$ APC tool data. 
Table 18. Depth to basement, thermal gradient, heat flow, and extrapolated temperature at the top of basement for the Buried Basement sites.

\begin{tabular}{ccccc}
\hline Hole & $\begin{array}{c}\text { Depth to basement }{ }^{\mathrm{a}} \\
(\mathrm{m})\end{array}$ & $\begin{array}{c}\text { Thermal gradient } \\
\left({ }^{\circ} \mathrm{C} / \mathrm{m}\right)\end{array}$ & $\begin{array}{c}\text { Heat flow }^{\mathrm{b}} \\
\left(\mathrm{mW} / \mathrm{m}^{2}\right)\end{array}$ & $\begin{array}{c}\text { Basement temperature }^{\mathrm{c}} \\
\left({ }^{\circ} \mathrm{C}\right)\end{array}$ \\
\hline 1028A & 130.5 & 0.373 & 457 & 50.5 \\
$1029 \mathrm{~A}$ & 220.1 & 0.258 & 341 & 58.7 \\
$1030 \mathrm{~B}$ & 46.9 & 0.817 & 956 & 40.1 \\
$1031 \mathrm{~A}$ & 41.3 & 0.931 & 1087 & 40.4 \\
$1032 \mathrm{~A}$ & 291.2 & 0.223 & 299 & 57.1 \\
\hline
\end{tabular}

${ }^{a}$ Depths to basement are based on driller's records.

${ }^{\mathrm{b}}$ Based on least-squares best fit of selected equilibrium temperature data.

${ }^{\mathrm{c}}$ Extrapolation of Bullard plot to cumulative thermal resistance appropriate for top of basement.

Table 19. Tool strings used and intervals logged in Hole 1032A.

\begin{tabular}{lcc}
\hline \multicolumn{1}{c}{ Tool string } & $\begin{array}{c}\text { Depth interval } \\
(\mathrm{mbrf})\end{array}$ & $\begin{array}{c}\text { Depth interval } \\
(\mathrm{mbsf})\end{array}$ \\
\hline Triple combination & $2643.2-2939.9$ & $-12.8-283.9$ \\
Formation MicroScanner & $2737.7-2937.5$ & $81.7-281.5$ \\
Geochemical & $2726.6-2933.2$ & $70.6-277.2$ \\
\hline
\end{tabular}

Figure 33. Gamma-ray, resistivity, density, and sonic data from Hole 1032A. Local variability in the curves reflect the alternation of muddy and sandy layers in the interval. The porosity log is shown in Figure 36.

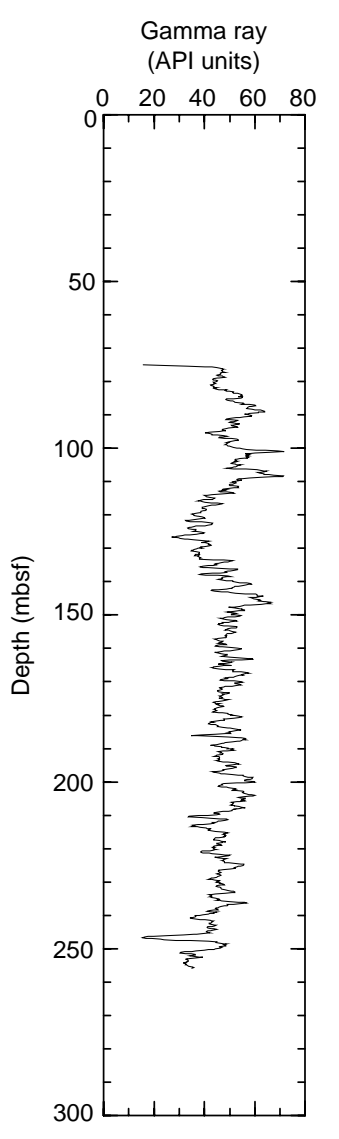

\begin{tabular}{|c|c|}
\hline & $\begin{array}{l}\text { eesistiv } \\
(\Omega \mathrm{m})\end{array}$ \\
\hline 0.50 & 0.75 \\
\hline
\end{tabular}
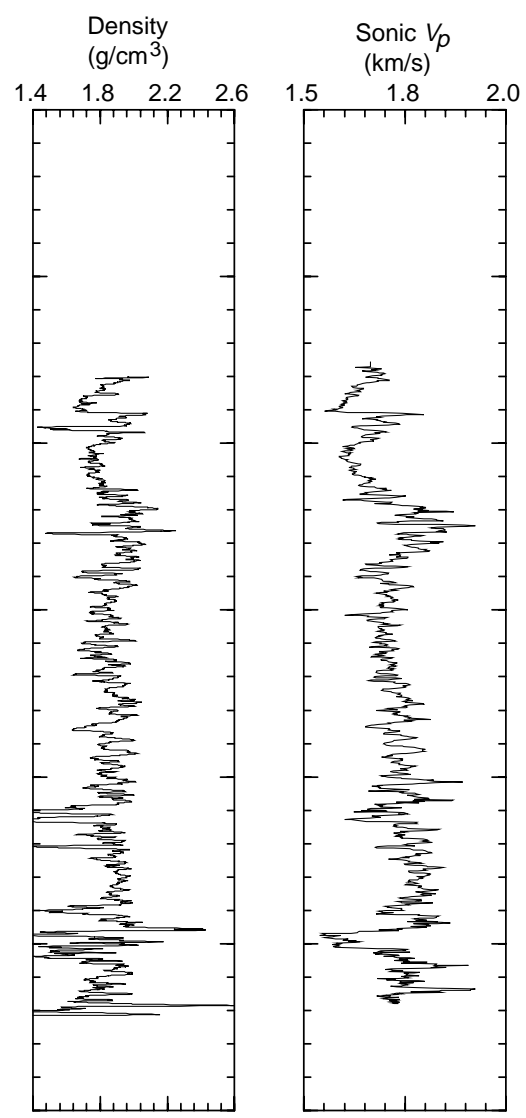


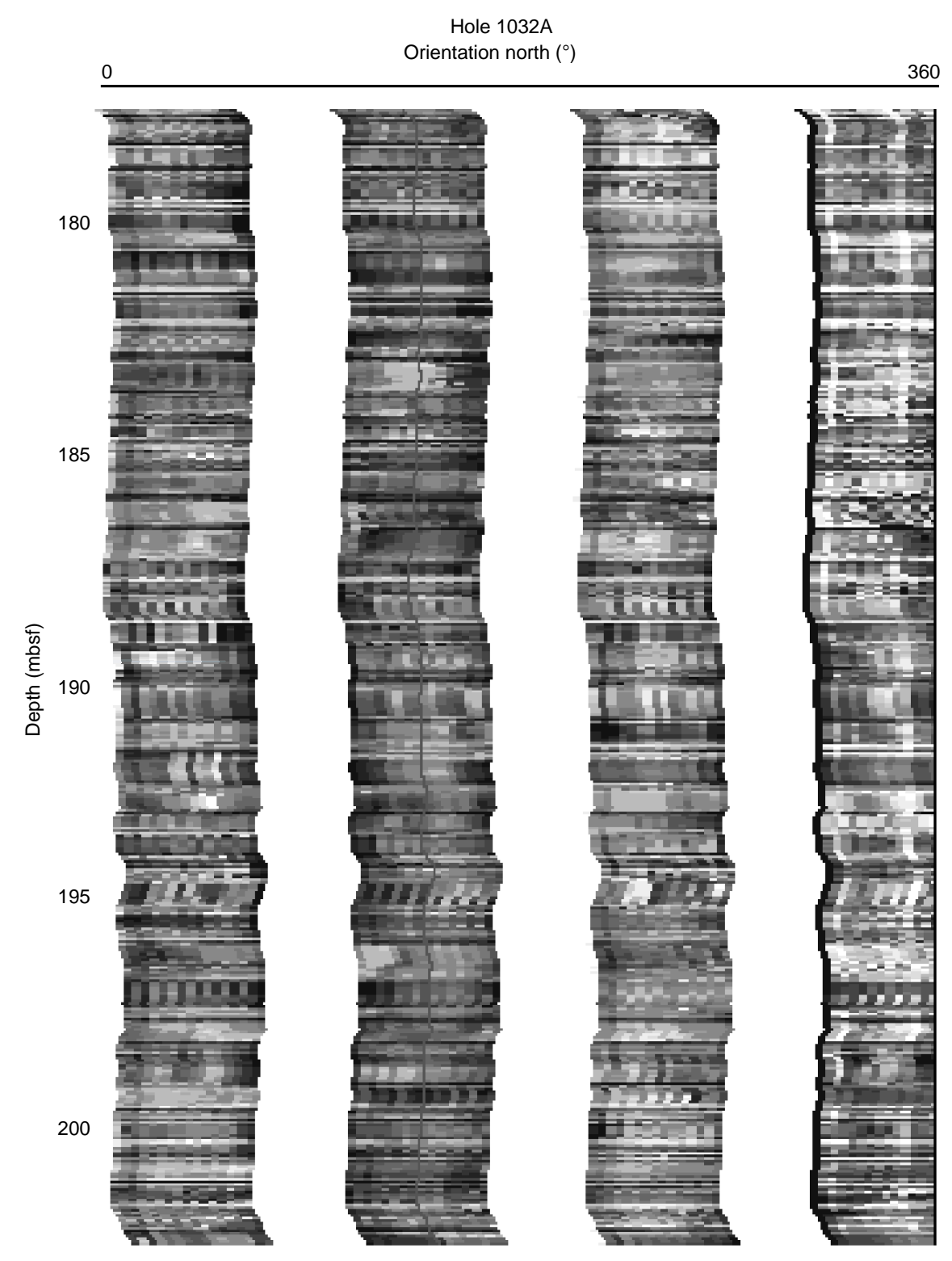

Figure 34. FMS images for the depth interval 180-200 mbsf in Hole 1032A, showing horizontal alternating layering of bright (sandy) and dark (muddy) layers. 


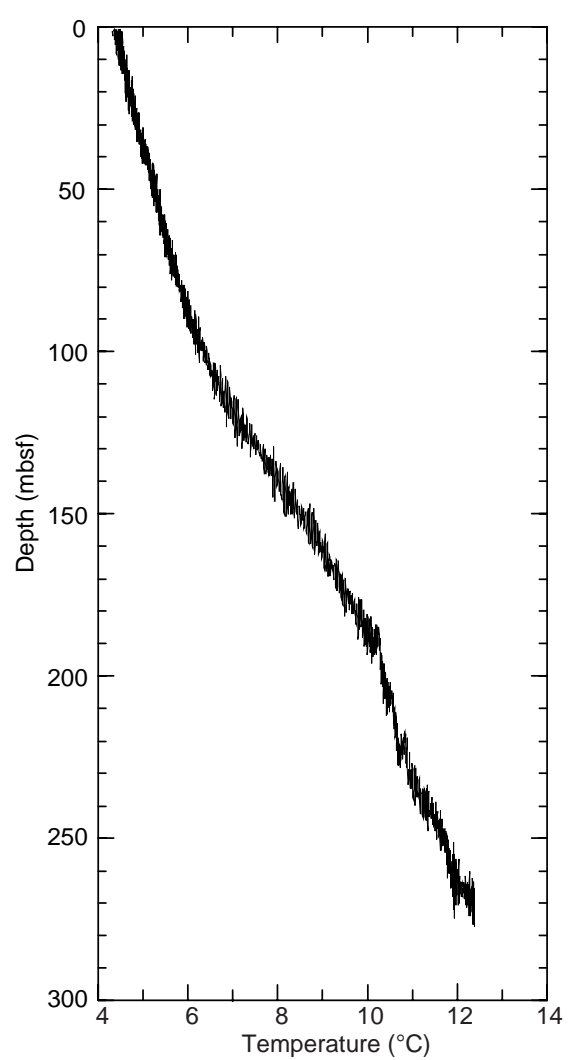

Figure 35. Temperatures measured by the LDEO temperature tool. Absolute temperatures are below those measured with the APC tool and the DVTP because of incomplete thermal recovery from drilling disturbance. 

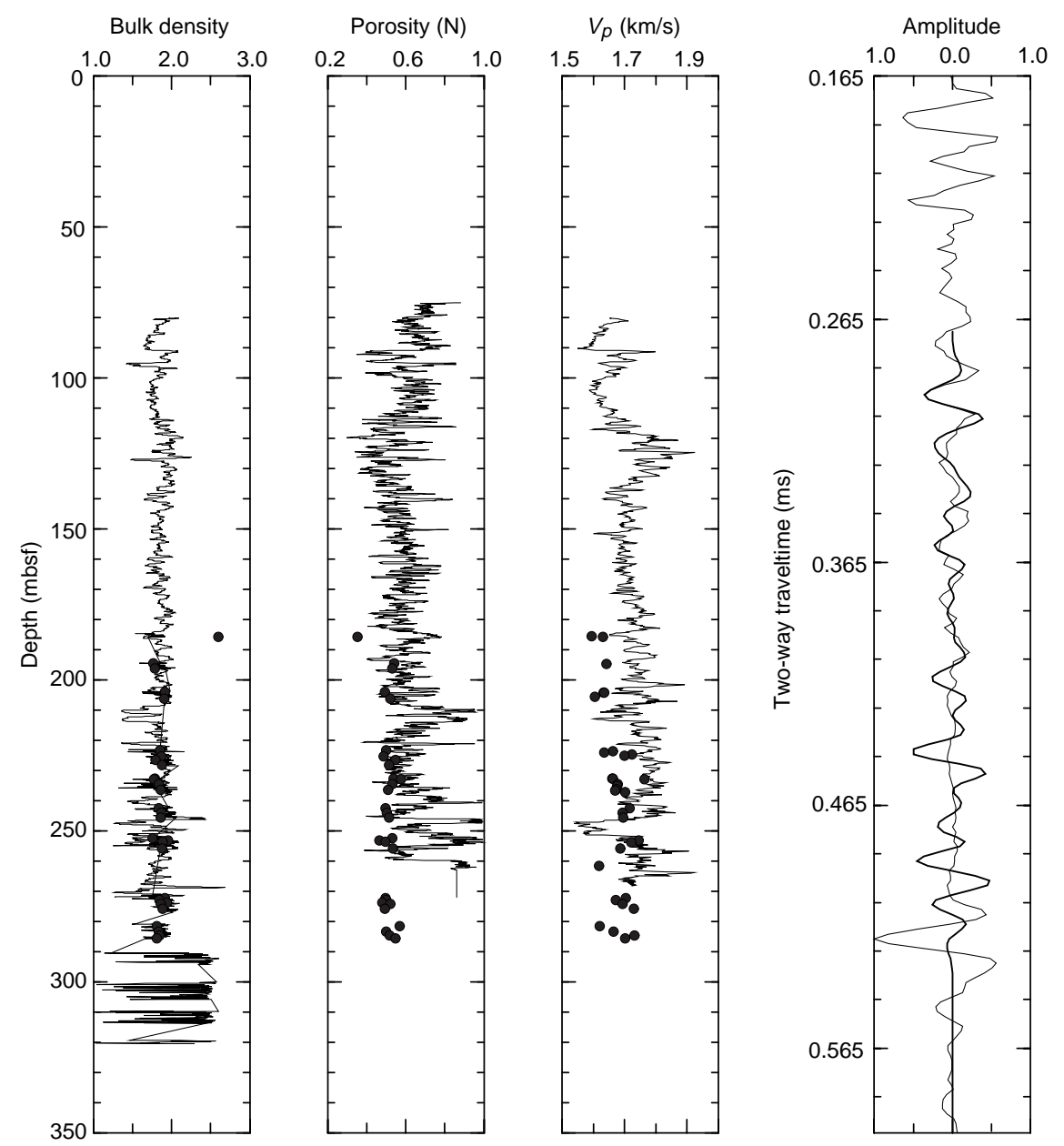

Figure 36. Core-log-seismic integration at Hole 1032A. Bulk density = high-resolution HLDT density log compared with core MST GRAPE density (dashed curve) and IP density (dots); porosity = neutron porosity log compared with IP data; $V_{p}=$ sonic $V_{p}$ data plotted with core DSV measurements; and amplitude $=$ synthetic seismogram (dark thick curve) generated by using corrected sonic $V_{p}$ and density logs, showing good match with real seismic trace (thin curve) in the upper part of the hole. The disagreement in the lower part is because of poor hole conditions. 


\section{SHORE-BASED LOG PROCESSING}

\section{Hole 1032A}

Bottom felt: 2656.5 mbrf (used for depth shift to seafloor)

Total penetration: $338.4 \mathrm{mbsf}$

Total core recovered: $50.9 \mathrm{~m}(33 \%)$.

\section{Logging Runs}

Logging string 1, triple combination: DIT/HLDT/APS/HNGS Logging string 2, Formation MicroScanner: FMS/GPIT/SDT/ NGT

Logging string 3, geochemical: ACT/GST/NGT

The wireline heave compensator was used for all logs.

\section{Bottom-Hole Assembly}

The following bottom-hole assembly depths are as they appear on the logs after differential depth shift (see "Depth shift" section) and depth shift to the seafloor. As such, there might be a discrepancy with the original depths given by the drillers on board. Possible reasons for depth discrepancies are ship heave, the use of a wireline heave compensator, and drill string and/or wireline stretch.

DIT/APS/HLDT/HNGS: Bottom-hole assembly at $\sim 75 \mathrm{mbsf}$

FMS/SDT/GPIT/NGT: Recorded in open hole (pass 1)

FMS/SDT/GPIT/NGT: Bottom-hole assembly at $\sim 75 \mathrm{mbsf}$ (pass 2)

ACT/GST/NGT: Bottom-hole assembly at $~ 75$ mbsf.

\section{Processing}

Depth shift: Original logs have been interactively depth shifted with reference to HNGS from DIT/APS/HLDT/HNGS run and to the seafloor (-2656.5 m).

Gamma-ray and environmental corrections: Corrections for borehole size and type of drilling fluid were performed on the NGT data from the FMS/GPIT/SDT/NGT tool string. HNGS data from the DIT/HLDT/APS/HNGS tool string were corrected in real time while recording.

Acoustic data processing: The array sonic tool was operated in standard depth-derived borehole compensated mode, including longspacing (8-10-10-12 ft) and short-spacing (3-5-5-7 ft) logs. The long spacing sonic logs have been processed to eliminate some noise and cycle skipping.

Geochemical processing: The elemental yields recorded by the GST tool represent the relative contribution of only some of the rockforming elements (iron, calcium, chlorine, silicon, sulfur, hydrogen, gadolinium, and titanium - the last two elements computed during geochemical processing) to the total spectrum. Because other rockforming elements are present in the formation (such as aluminum, potassium, etc.), caution is recommended in using the yields to infer lithologic changes. Instead, ratios should be used to estimate changes in the macroscopic properties of the formation.

List of oxide factors used in geochemical processing:

$\mathrm{SiO}_{2}=2.139$

$\mathrm{CaO} / \mathrm{CaCO}_{3}=1.399-2.497$

$\mathrm{FeO}^{*}=1.358$

$\mathrm{TiO}_{2}=1.668$

$\mathrm{K}_{2} \mathrm{O}=1.205$

$\mathrm{Al}_{2} \mathrm{O}_{3}=1.889$

$\mathrm{FeO}^{*}=$ computed using an oxide factor which assumes a 50:50 combination of $\mathrm{Fe}_{2} \mathrm{O}_{3}$ and $\mathrm{FeO}$ factors.

VARCA $=$ variable $\mathrm{Ca}$ oxide/carbonate factor used in $\mathrm{CaO} /$ $\mathrm{CaCO}_{3}$ calculation.

The estimate of $\mathrm{Al}_{2} \mathrm{O}_{3}$ dry weight percent presents some unusually high values throughout the entire hole, which could be related to the use of sepiolite mud or to the Californium source on the geochemical tool being too weak. The oxide data should therefore be used qualitatively.

\section{Quality Control}

Null value $=-999.25$. This value generally appears in discrete core measurement files, and also it may replace recorded log values or results that are considered invalid (e.g., processed sonic data).

During the processing, quality control of the data is mainly performed by cross-correlation of all logging data. Large (>12 in) and/ or irregular boreholes affect most recordings, particularly those requiring eccentralization (CNTG and HLDT) and a good contact with the borehole wall. Hole deviation can also affect the data negatively; the FMS, for example, is not designed to be run in holes deviated more than $10^{\circ}$ because the tool weight might cause the caliper to close.

Data recorded through bottom-hole assembly, such as the HNGS/ NGT data above $75 \mathrm{mbsf}$, should be combined qualitatively because of the attenuation on the incoming signal.

Hole diameter was recorded by the hydraulic caliper on the HLDT tool (CALI) and on the FMS string (C1 and C2).

$\mathrm{FACT}=$ quality control curve in geochemical processing. Accuracy of the estimates is inversely proportional to the magnitude of the curve.

Details of standard shore-based processing procedures are referenced and discussed in the "Methods" chapter (this volume) and in the geochem.doc documentation file included in the ODP-BRG Log Data CD-ROM (back pocket). For further information about the logs, please contact:

Cristina Broglia

Phone: 914-365-8343

Fax: 914-365-3182

E-mail: chris@1deo.columbia.edu
Zhiping Tu

Phone: 914-365-8336

Fax: 914-365-3182

E-mail: ztu@1deo.columbia.edu 


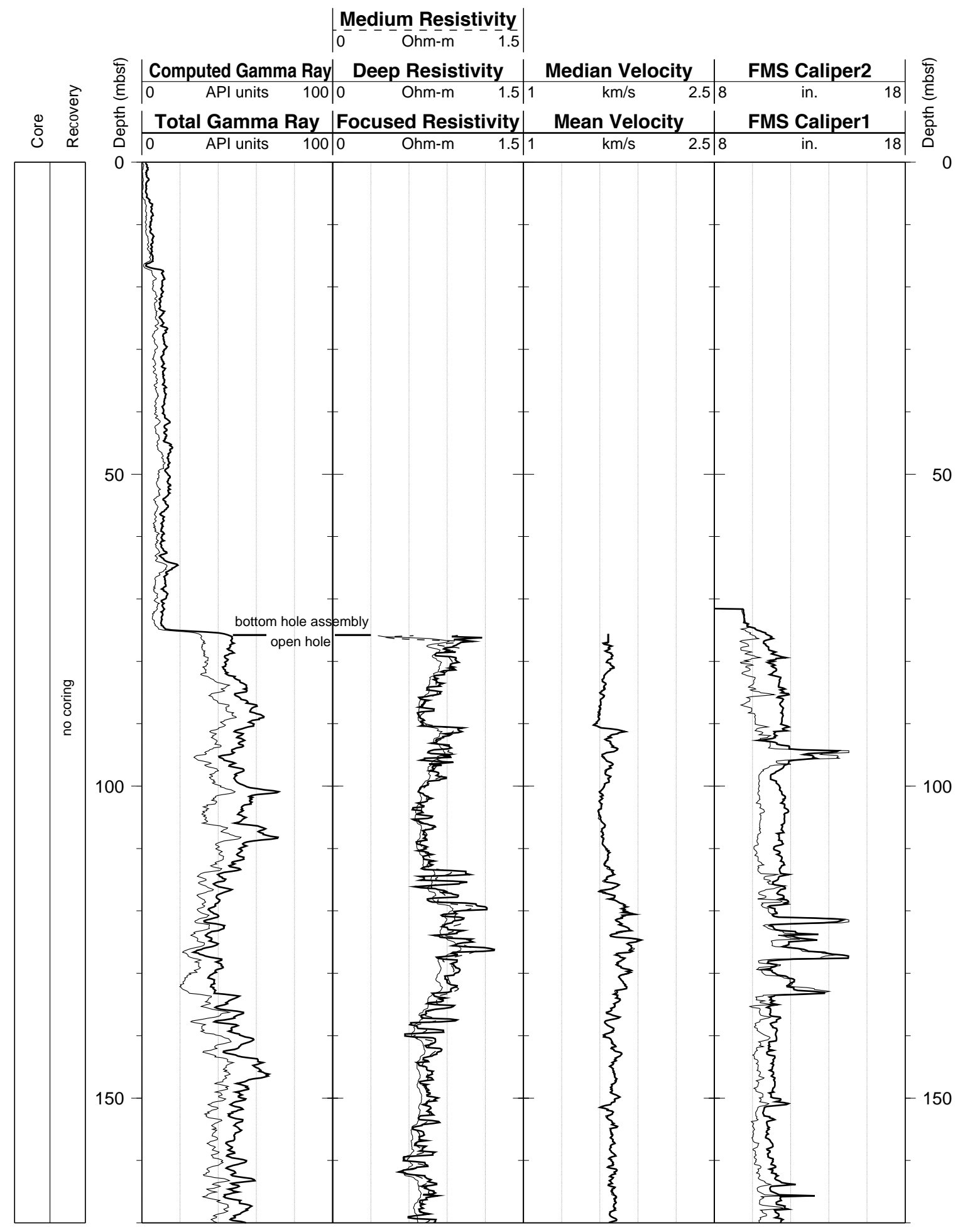


Hole 1032A: Natural Gamma Ray-Resistivity-Sonic Logging Data (cont.)

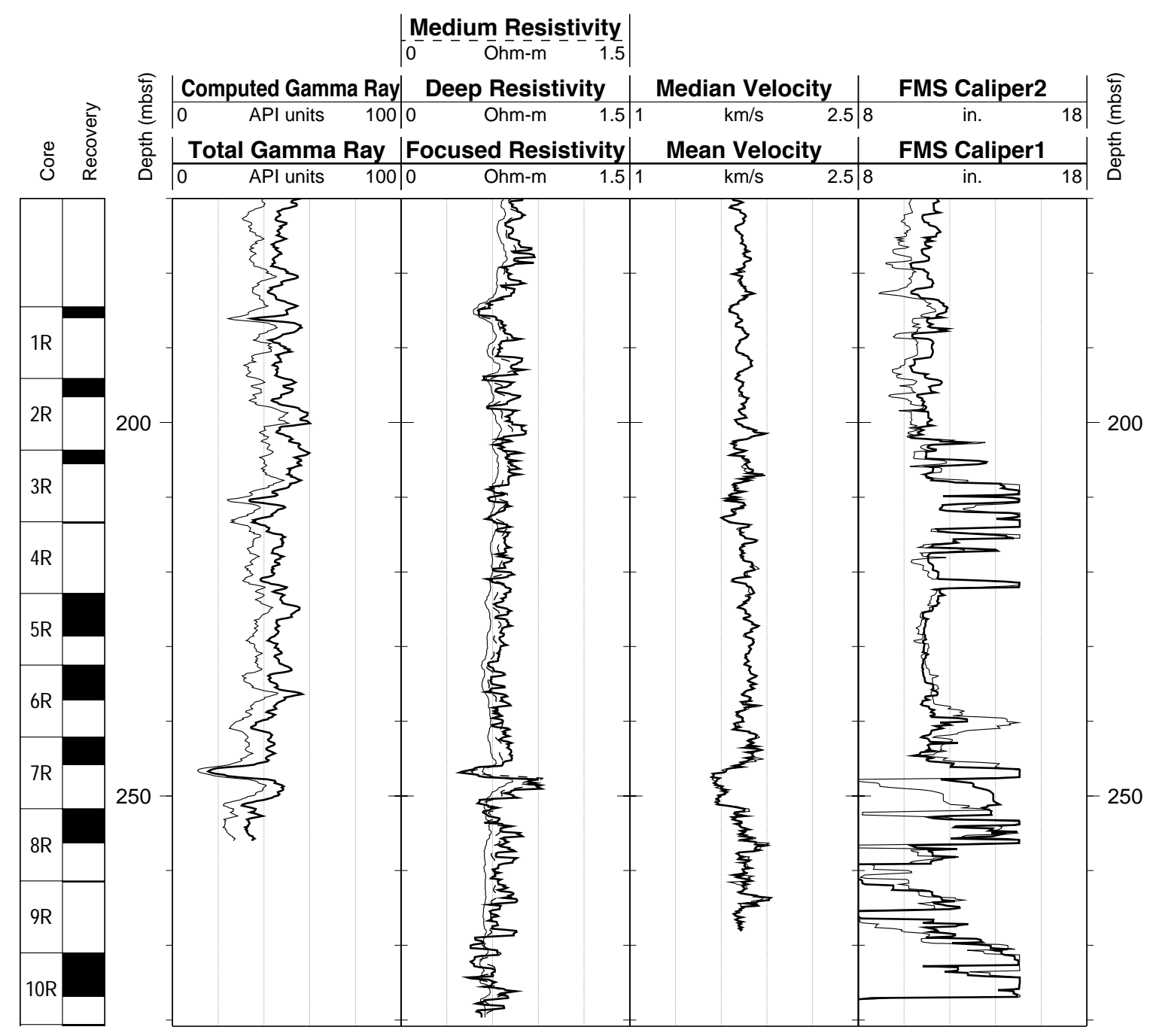




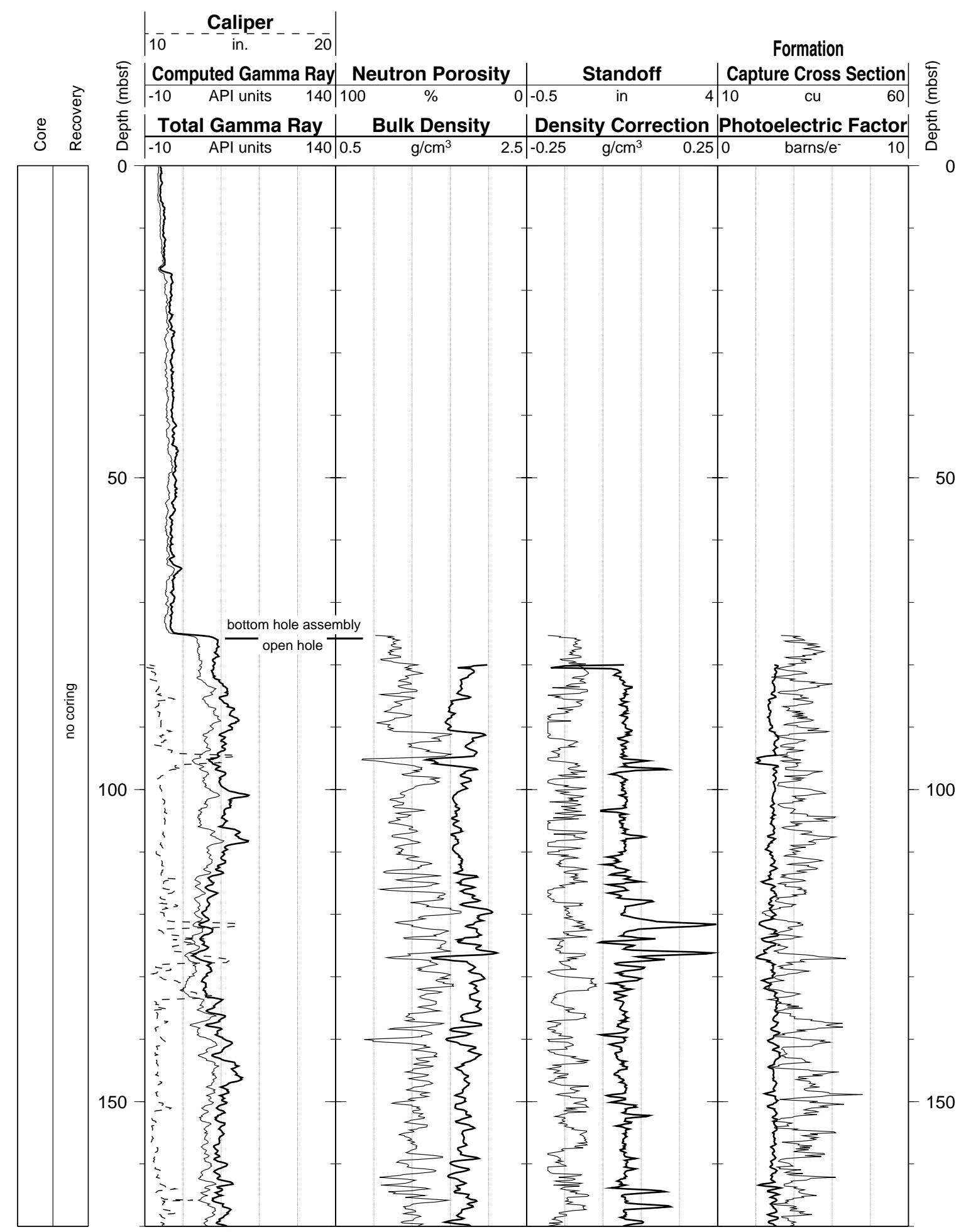




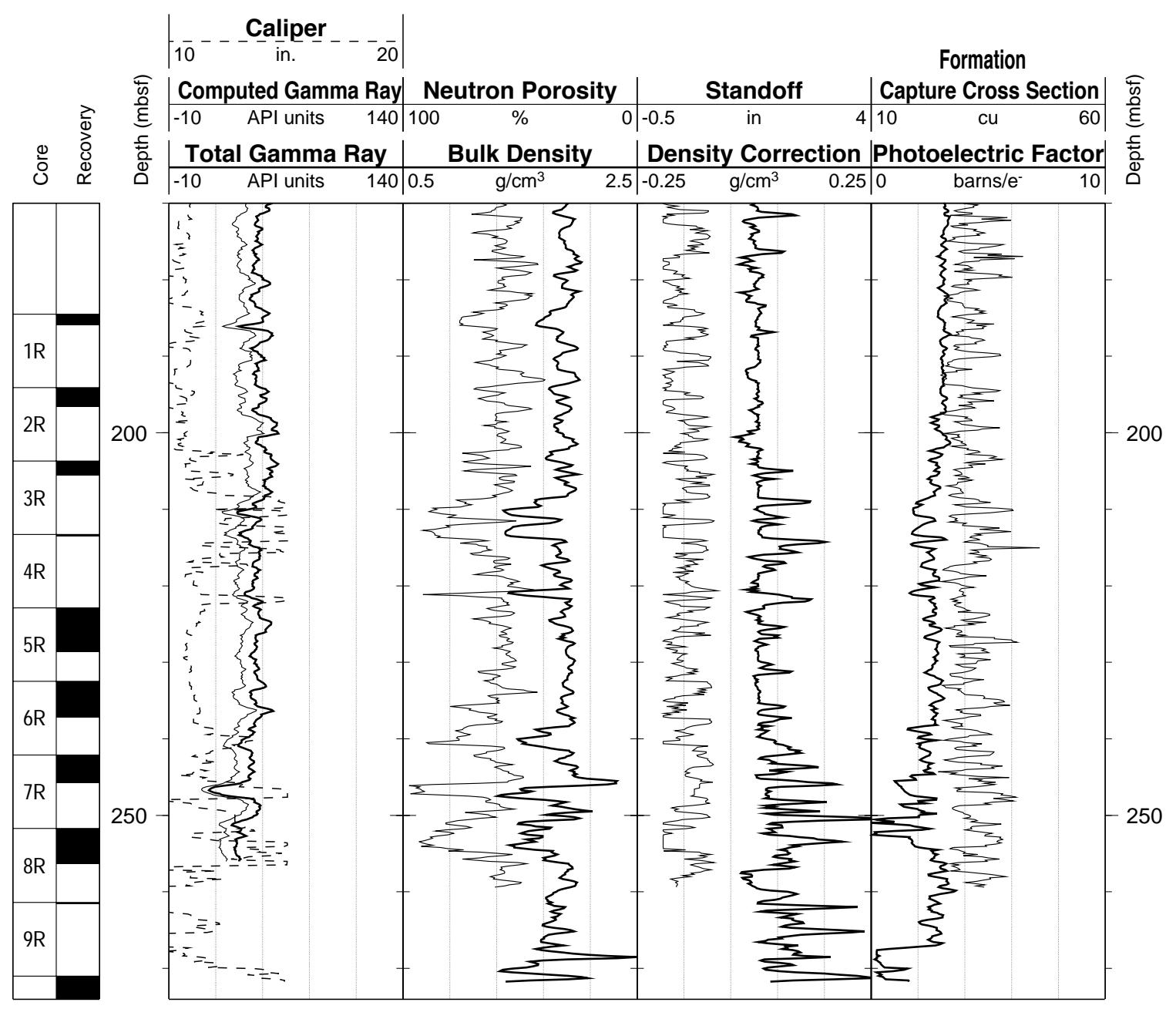


Hole 1032A: Natural Gamma Ray Logging Data

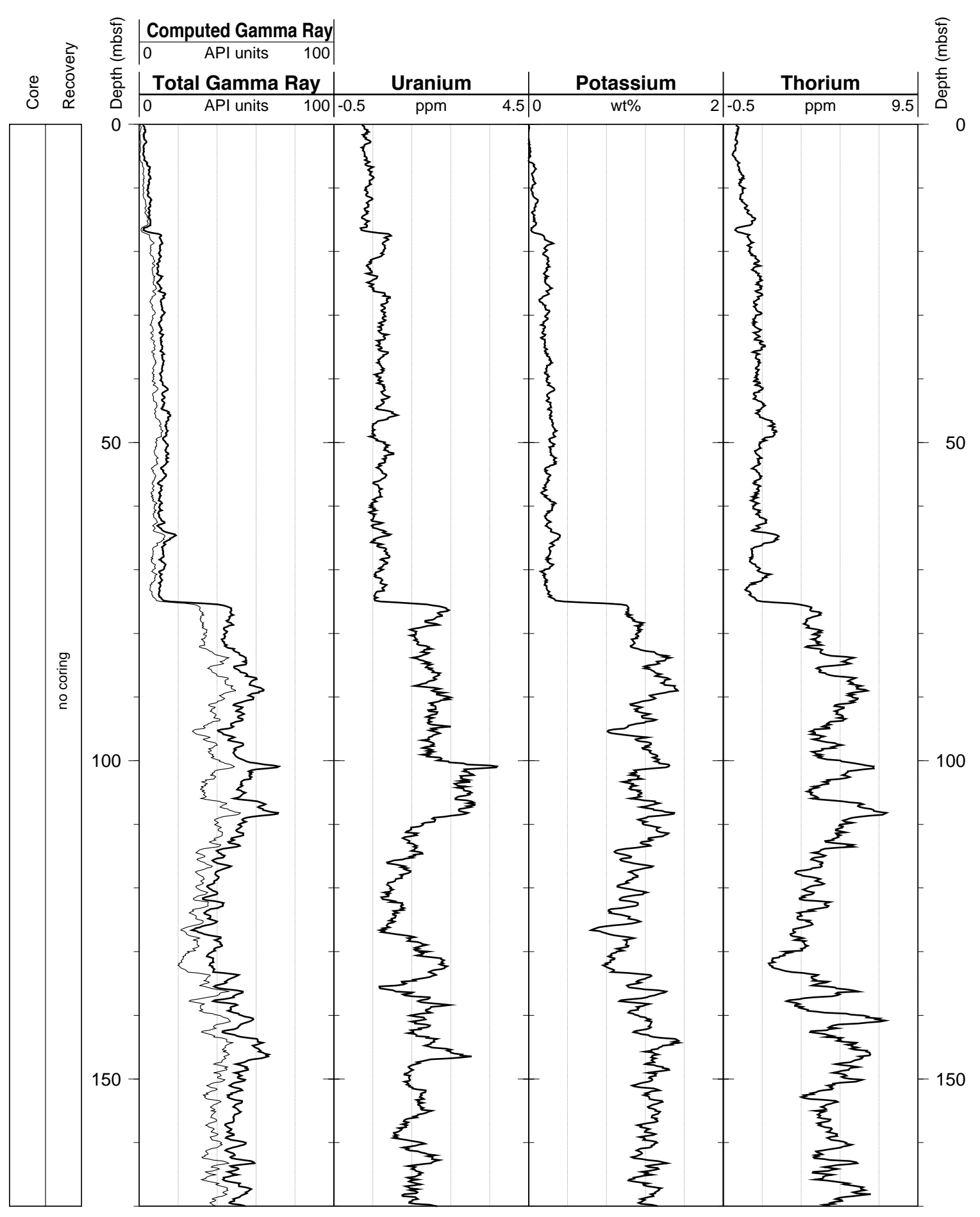




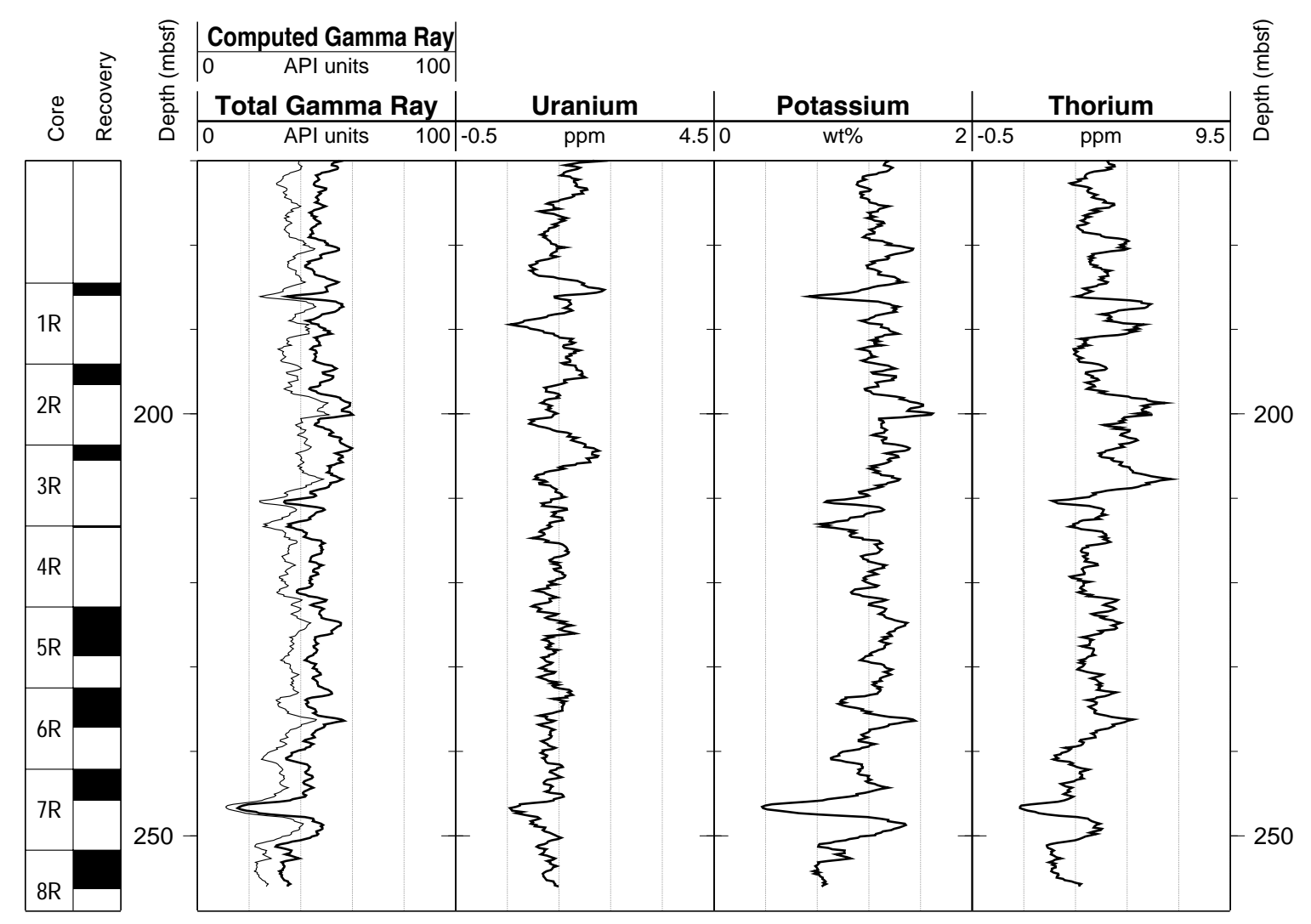




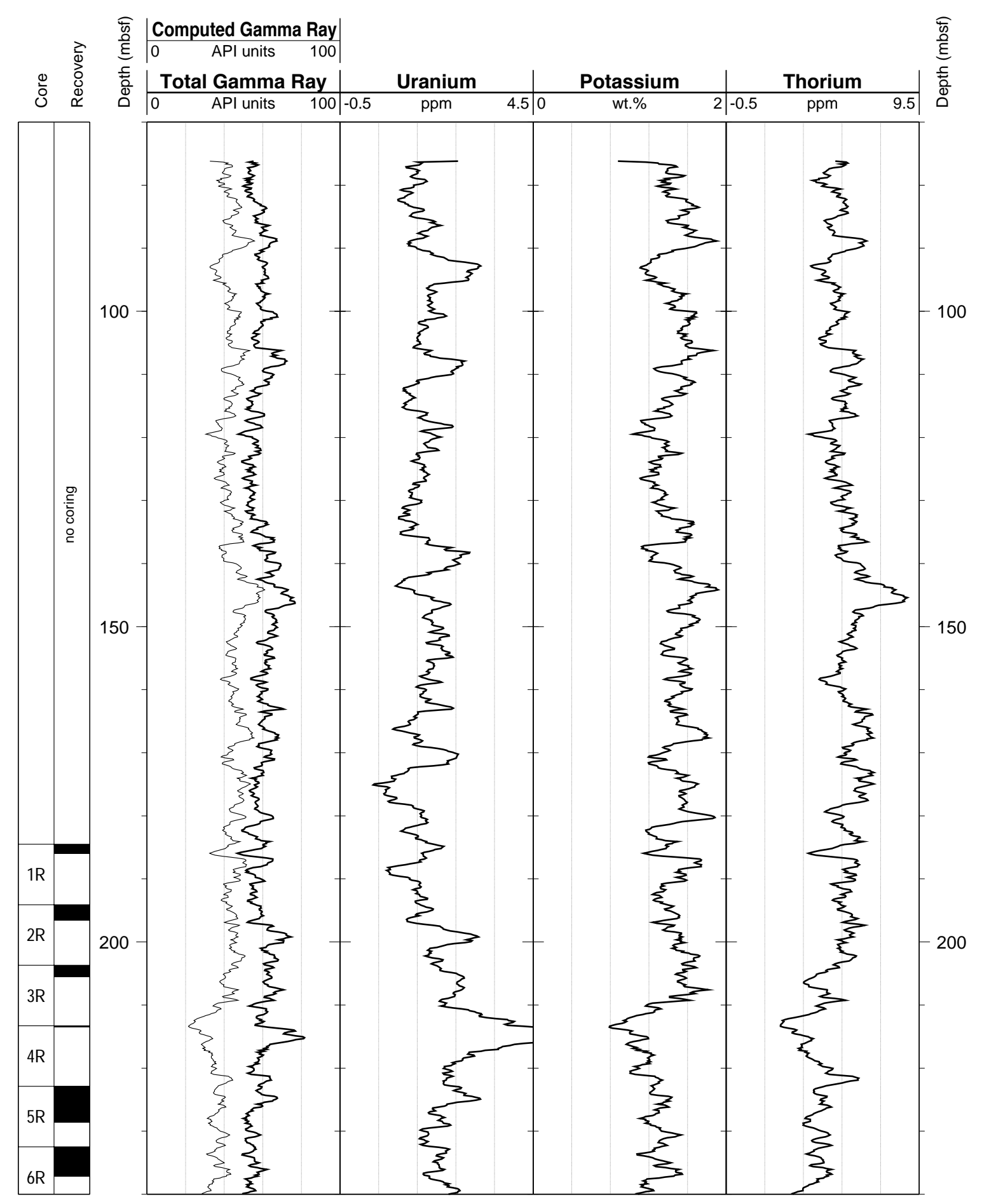


Hole 1032A: Natural Gamma Ray Logging Data (cont.)

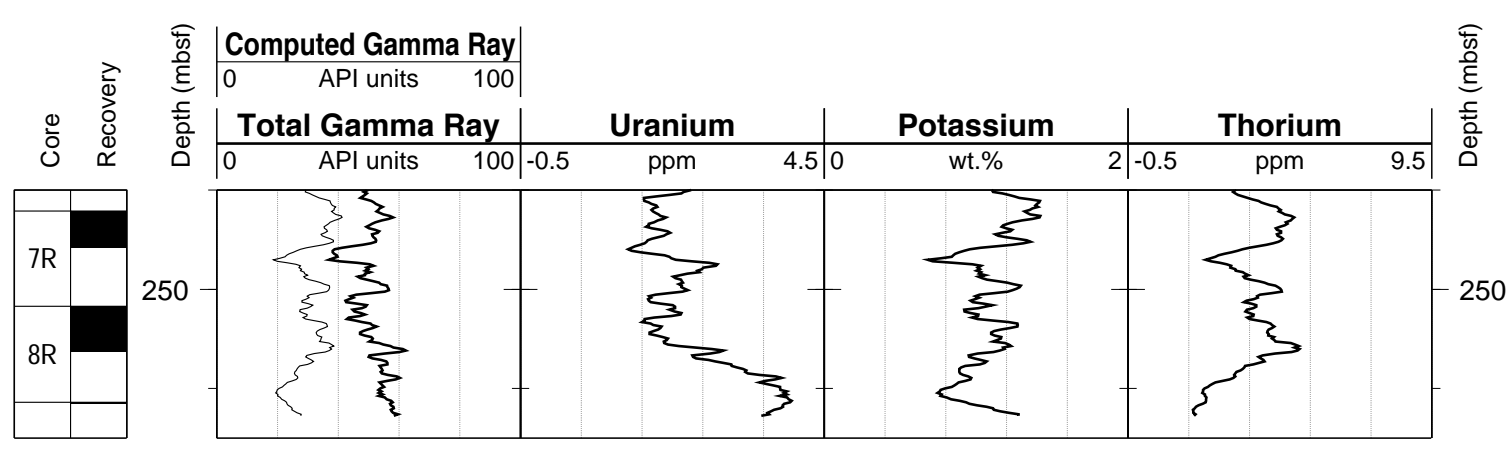


Hole 1032A: Geochemical Logging Data
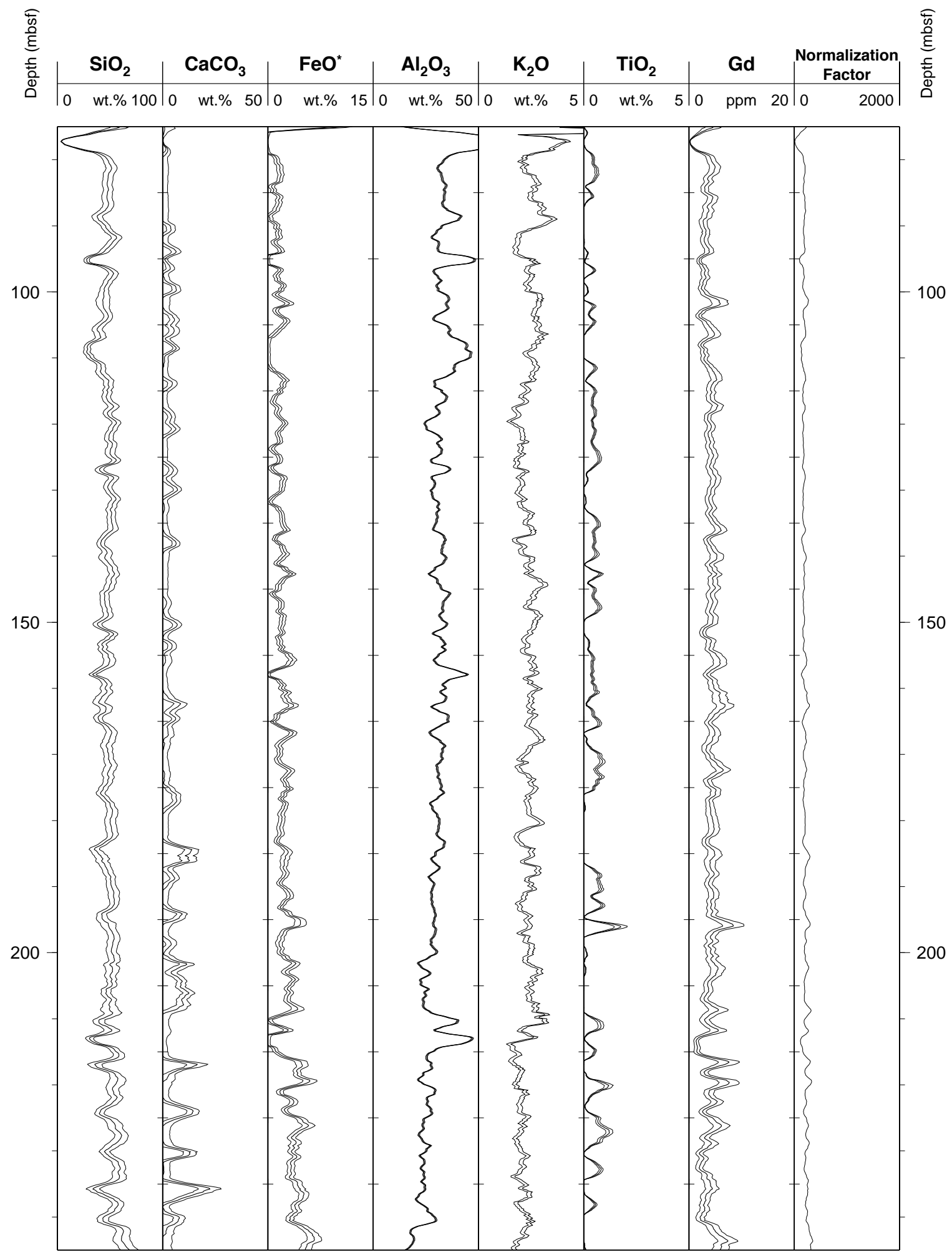
Hole 1032A: Geochemical Logging Data (cont.)
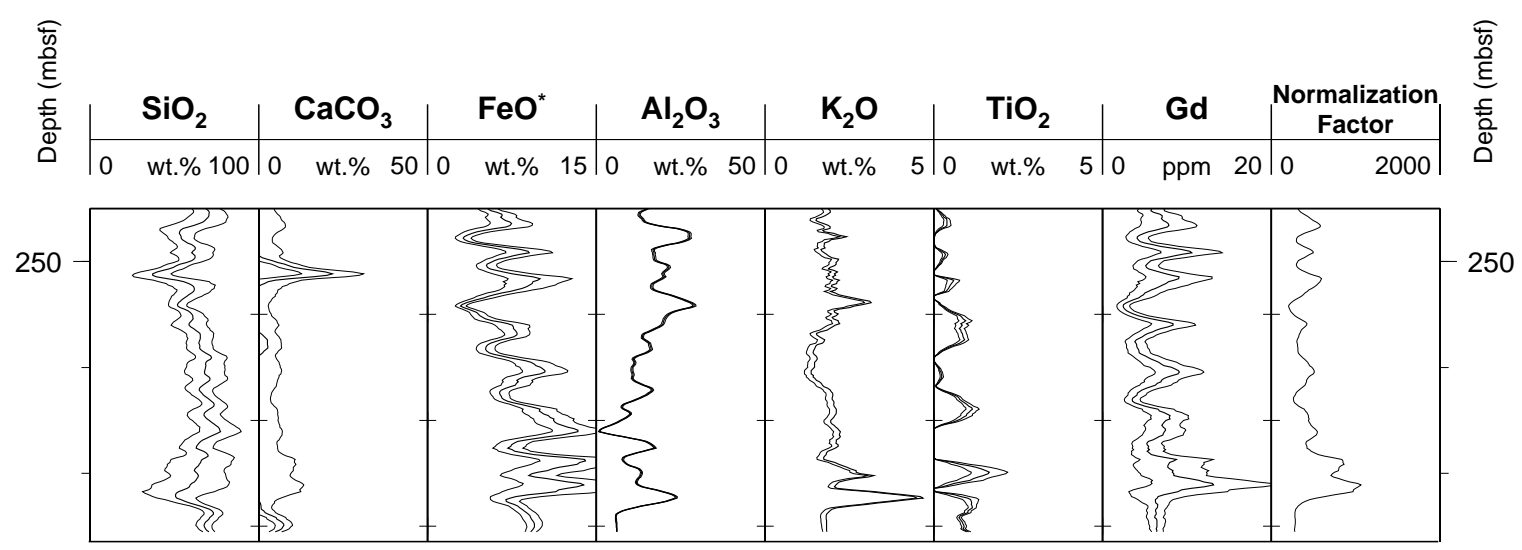